\title{
THE SMART GROWTH IMPLICATIONS OF THE LOS ANGELES ADAPTIVE REUSE ORDINANCE
}

\author{
A Thesis \\ presented to \\ the Faculty of California Polytechnic State University, \\ San Luis Obispo

\begin{abstract}
In Partial Fulfillment
of the Requirements for the Degree

Master of City and Regional Planning
\end{abstract} \\ By \\ John Forrest Chamberlain
}

June 2015 
(C) 2015

John Forrest Chamberlain

ALL RIGHTS RESERVED 


\section{COMMITTEE MEMBERSHIP}

TITLE:

The Smart Growth Implications of the Los Angeles Adaptive Reuse Ordinance
AUTHOR:
John Forrest Chamberlain

DATE SUBMITTED: June 2015

COMMITTEE CHAIR: $\quad$ William Riggs, Ph.D., AICP, LEED AP Assistant Professor of City and Regional Planning

COMMITTEE MEMBER: Hemalata C. Dandekar, Ph.D.

Professor \& Department Head, City and Regional Planning

COMMITTEE MEMBER: Margot McDonald, AIA, NCARB, LEED BD+C Professor \& Department Head, Architecture 


\begin{abstract}
The Smart Growth Implications of the Los Angeles Adaptive Reuse Ordinance John Forrest Chamberlain
\end{abstract}

The Los Angeles Adaptive Reuse Ordinance (ARO) is an incentive program that encourages building reuse through regulatory exemptions. The ARO was partially intended to reduce vehicle miles travelled by encouraging mixed commercial and residential uses in existing buildings within Downtown Los Angeles and areas poised for redevelopment (Mayor's Office of Economic Development, 2004, pp. 22, 51). Researchers and planners claim that the ARO helped to reduce vehicle miles travelled (Bell, 2014; Los Angeles Department of City Planning, 2014d; Bullen \& Love, 2009; Bernstein, 2012), but these claims are not supported by discussions of the spatial distribution of ARO projects in relation to transit, or if the ARO accelerated, or hindered, infill transit-oriented development projects. This thesis aims to better understand the contributions of the ARO to transit-oriented growth in the City of Los Angeles. Two methods of analysis are used: a spatial analysis examining the number of ARO projects within a half-mile radius of Metro stations, and a statistical analysis examining the number of new buildings constructed in Downtown Los Angeles from 1985 to 2013. The majority of ARO projects (72\%) have been developed within a half-mile radius of Metro rail stations. The ARO appears to have accelerated downtown development activity since its adoption in 1999, reversing a lull in development that had been occurring in the area since the late 1980s. Findings suggest that the ARO has helped to accommodate and spur transit-oriented growth while preserving historic resources in the City of Los Angeles. 


\section{ACKNOWLEDGMENTS}

To my family, friends, thesis committee members, fellow MCRP graduates, Professor William Riggs, JRE, and my dog Peggie. Thanks to my mentors in the San Francisco Planning Department - Mary Brown, Tim Frye, Kelly Wong, and Kate McGee. A special thanks to Bryan Eck of the Los Angeles Department of Planning for providing me with invaluable data used in this thesis. 


\section{TABLE OF CONTENTS}

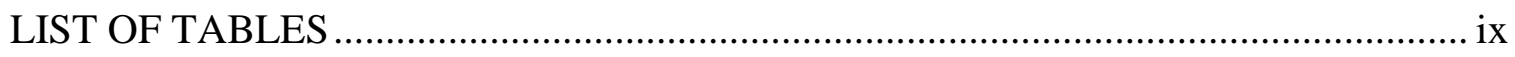

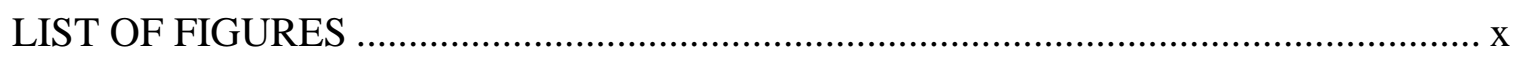

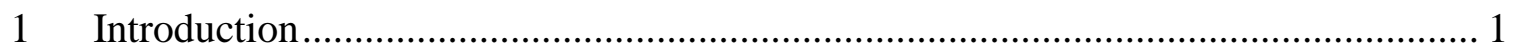

1.1 The Los Angeles Adaptive Reuse Ordinance .................................................. 1

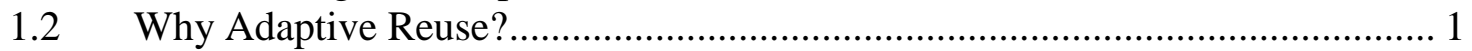

$1.3 \quad$ Sustainability and Adaptive Reuse ……………............................................ 3

1.4 Smart Growth and the Los Angeles Adaptive Reuse Ordinance......................... 4

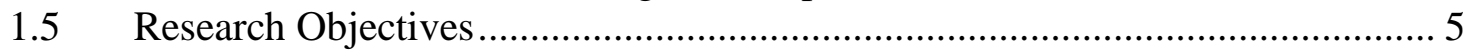

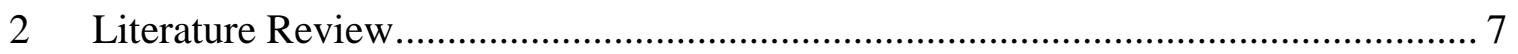

2.1 Adaptive Reuse and Sustainability …………………...................................... 7

2.1.1 Embodied energy and avoided environmental impacts ................................. 7

2.1.2 Energy efficiency ............................................................................... 9

2.1.3 Urban revitalization and smart growth ................................................... 10

2.1.4 Cultural heritage and sense of place …………......................................... 11

2.2 Adaptive Reuse: Sustainability Conflicts ....................................................... 12

2.2.1 Difficulty in retrofitting and rehabilitating historic buildings ...................... 13

2.2.2 Historic preservation impeding development .............................................. 14

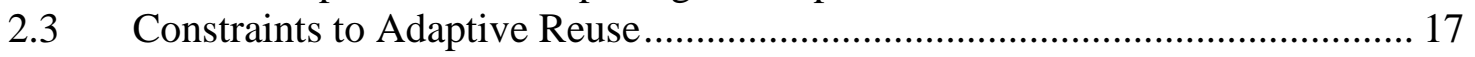

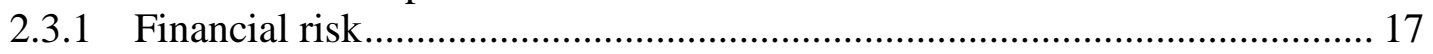

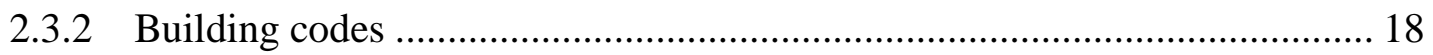

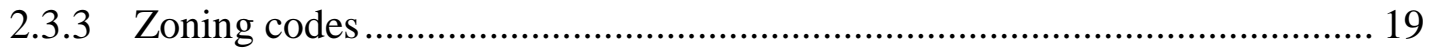

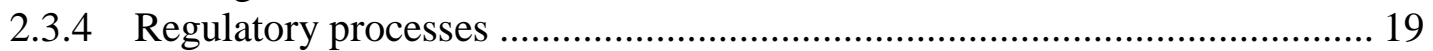

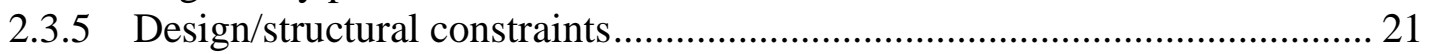

2.4 Methods Used to Incentivize Adaptive Reuse ................................................ 22

2.4.1 Flexible building and zoning codes ............................................................ 22

2.4.2 Adaptive reuse programs/polices ................................................................ 23

3 The Los Angeles Adaptive Reuse Ordinance …………....................................... 24

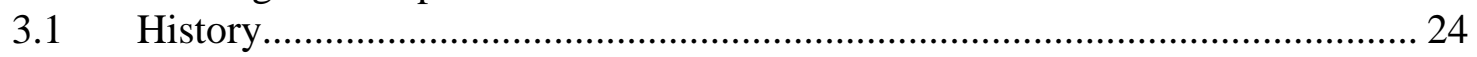

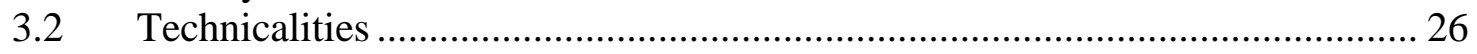

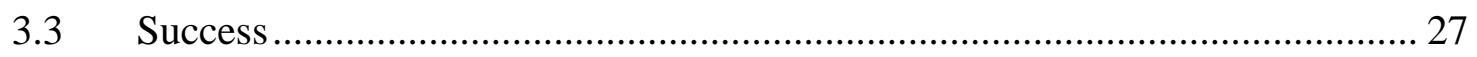

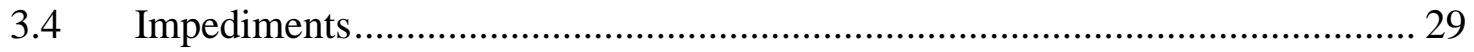

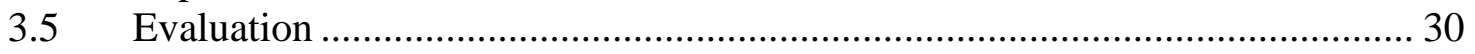

$4 \quad$ Sprawl and Smart Growth in Los Angeles …………............................................ 32

4.1 Sprawl and auto dependency in Los Angeles: A historical context.................. 32

4.1.1 Streetcar suburbs .................................................................................. 32

4.1.2 The early proliferation of automobile use .................................................... 33

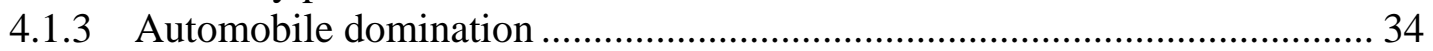

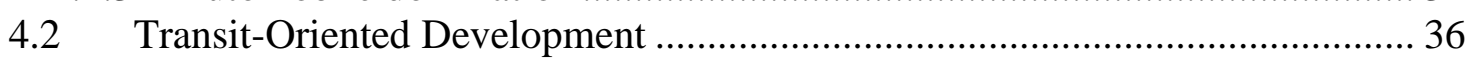

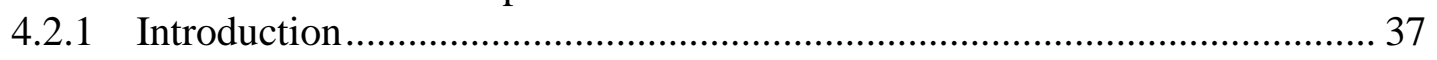

4.2.2 SB 375 and Sustainable Communities Strategy.......................................... 38

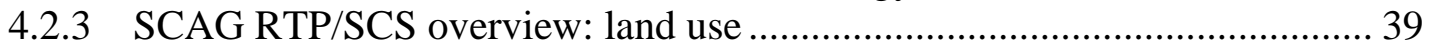

4.2.4 Local transit-oriented land use planning ....................................................... 41 
4.3 Complete Streets and Active Transportation ................................................ 44

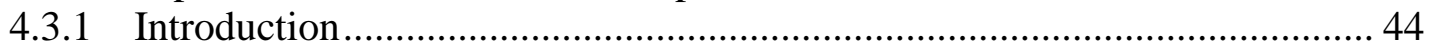

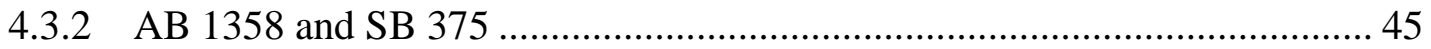

4.3.3 SCAG RTP/SCS overview: active transportation........................................ 46

4.3.4 Local active transportation planning.......................................................... 47

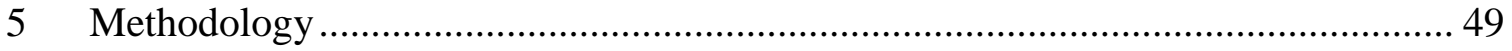

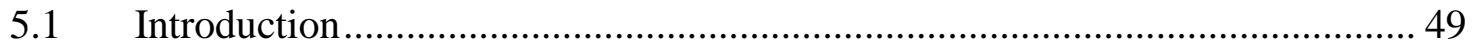

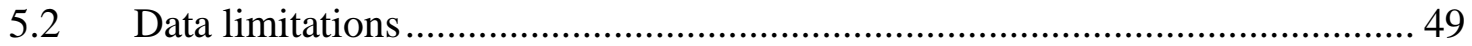

5.2.1 ARO projects ………………………………................................... 49

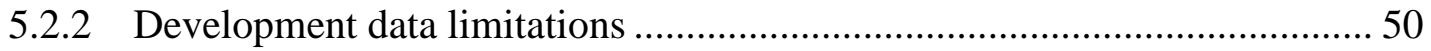

5.3 Metro Station Spatial Analysis ………………....................................... 52

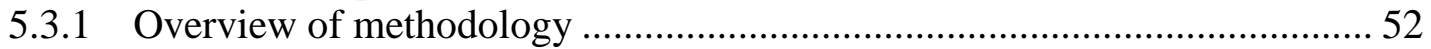

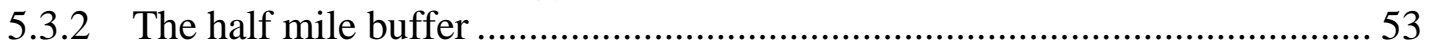

5.4 Development Trend Analysis - Central City Area ............................................... 58

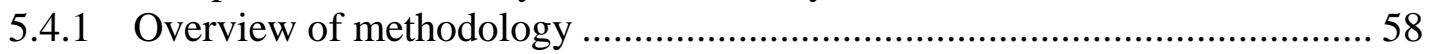

5.4.2 Justification for Central City focus ............................................................. 58

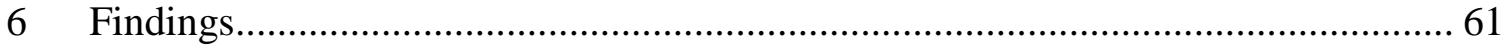

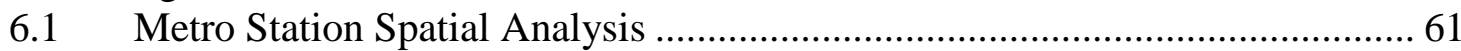

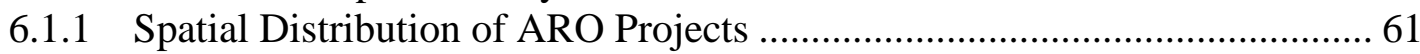

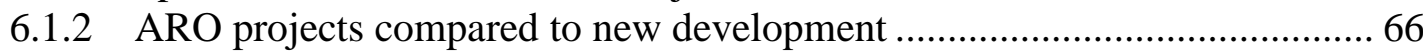

6.2 Development Trend Analysis - Central City Area ……………....................... 69

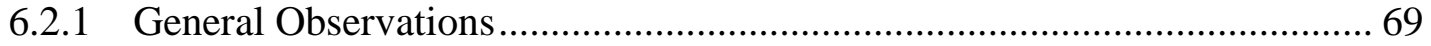

6.2.2 Relationship between new development and ARO projects.......................... 69

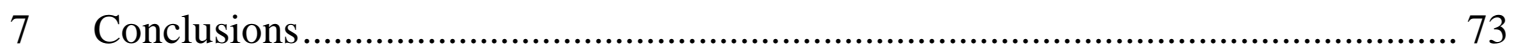

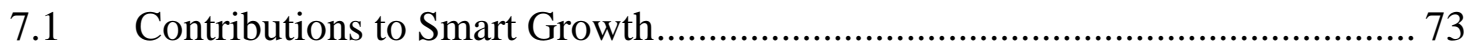

7.2 Softening the Impact of the Recession.......................................................... 75

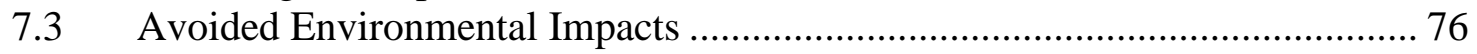

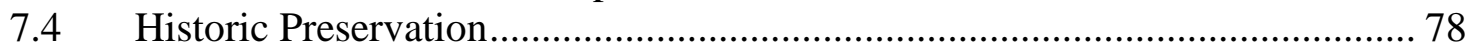

7.5 The Future of Adaptive Reuse in Los Angeles .............................................. 81

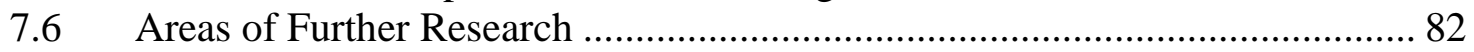

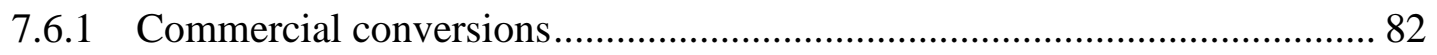

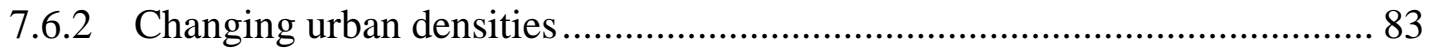

7.6.3 Complete streets in Downtown Los Angeles ................................................ 83

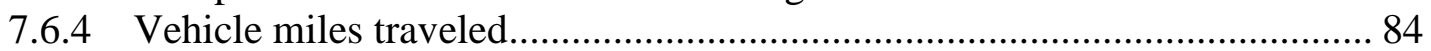

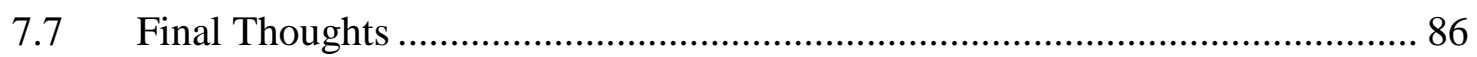

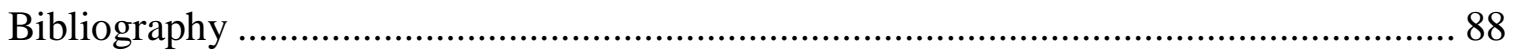

Appendices

Appendix A: Spatial Analysis, Buffer Analysis Around Metro Stations .................... 103

Appendix B: Buffer Analysis Around Metro Stations (Permit Data)......................... 110

Appendix C: ARO Projects in High Quality Transit Areas (HQTA) and Transit

Priority Areas (TPA) ....................................................................................... 113

Appendix D: ARO Projects Located in Higher-Intensity Land Use Districts ............ 116

Appendix E: ARO Project Data ............................................................................... 122

ARO Project 1-90 (Part One) .......................................................................... 122 
ARO Project 1-90 (Part Two) 


\section{LIST OF TABLES}

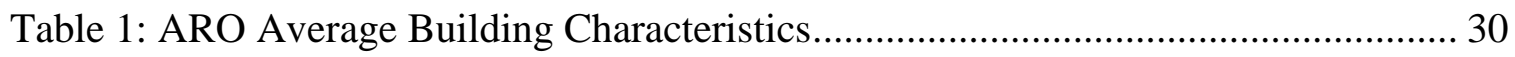

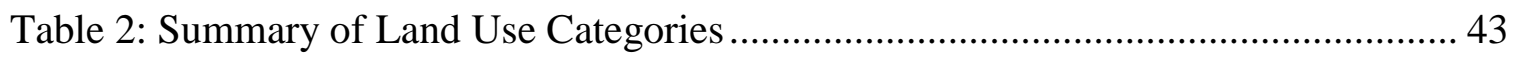

Table 3: ARO Project Characteristics Inside Higher-Intensity Land Use Districts......... 57

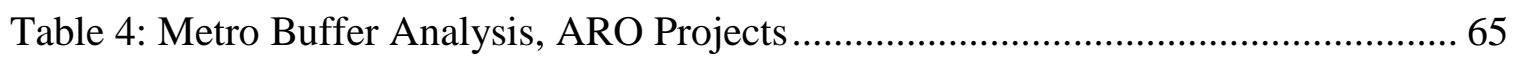

Table 5: Metro Buffer Analysis, Buildings Constructed Between 1999 and 2013 .......... 65

Table 6: ARO Projects Compared to Buildings Constructed Between 1999 and 2013 66

Table 7: ARO Projects Compared to New Development, Central City Area................... 67

Table 8: ARO Projects and New Development, 1985 to 2013 ....................................... 71

Table 9: Metro Buffer Analysis, New Buildings ...................................................... 103

Table 10: Metro Buffer Analysis, ARO Projects ..................................................... 104

Table 11: Metro Buffer Analysis, Community Plan Areas.......................................... 105

Table 12: ARO Projects Compared to Buildings Constructed Between 1999 and 2013,

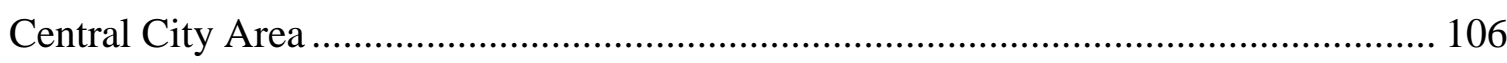

Table 13: Metro Buffer Analysis, Building Permits (January 2013 - January 2015)

Table 14: ARO Projects Compared to New Development Permits .............................. 113

Table 15: ARO Projects in HQTAs and TPAs ...................................................... 113

Table 16: New Development Permits (2013 - 2015) in HQTAs and TPAs................... 114

Table 17: HQTAs - ARO Projects Compared to New Development Permits ................ 114

Table 18: ARO Projects Regional Inside Regional Land Use Centers......................... 116

Table 19: Development Permits (2013-2015) Inside Regional Land Use Centers......... 116

Table 20: ARO Projects and Development Permits, Regional Land Use Centers.......117

Table 21: ARO Projects Inside Community Land Use Centers ................................... 117

Table 22: Development Permits (2013-2015) Inside Community Land Use Centers .... 118

Table 23: ARO Projects and Development Permits, Community Land Use Centers.... 118 


\section{LIST OF FIGURES}

Figure 1: Distribution of ARO Projects in Relation to Incentive Areas ......................... 31

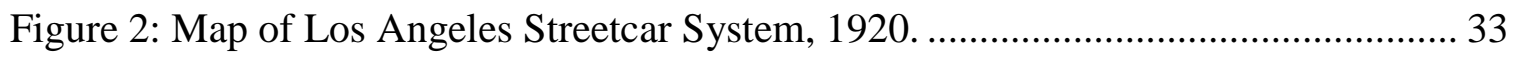

Figure 3: Process of Obtaining Building Age Data ................................................ 52

Figure 4: Map of SCAG High Quality Transit Areas and Transit Priority Areas ............ 55

Figure 5: Map of Select Regional and Community Land Use Districts ......................... 56

Figure 6: ARO Projects Inside Higher-Intensity Land Use Districts ............................ 57

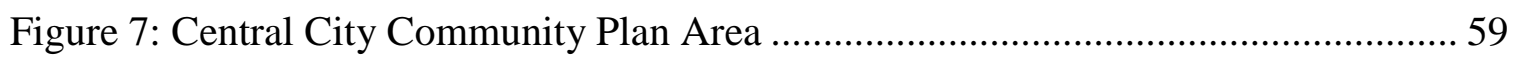

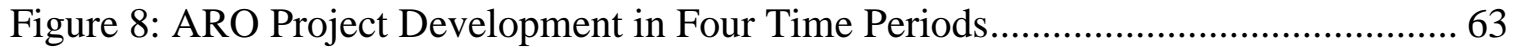

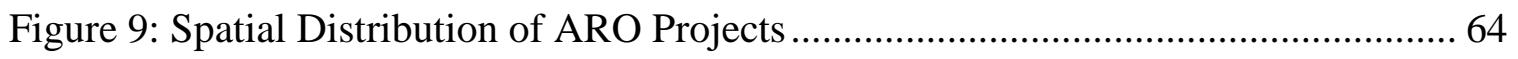

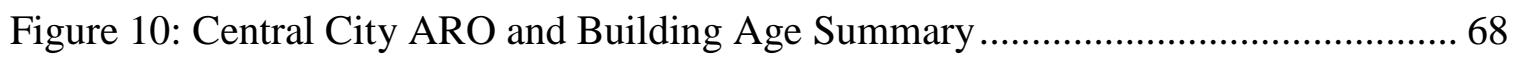

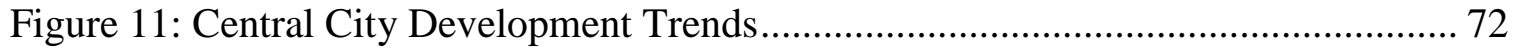

Figure 12: Central City Development Trends, New Development and ARO Projects .... 72

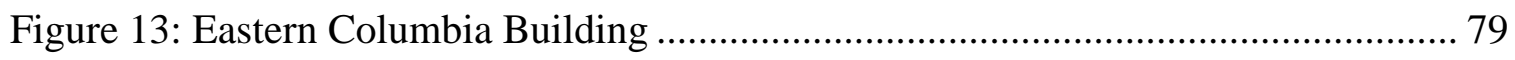

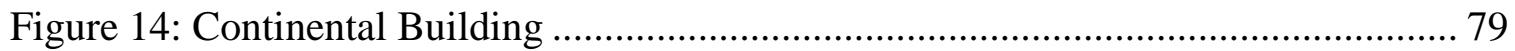

Figure 15: Primary facade of Barker Block Warehouse No.1 ….................................. 80

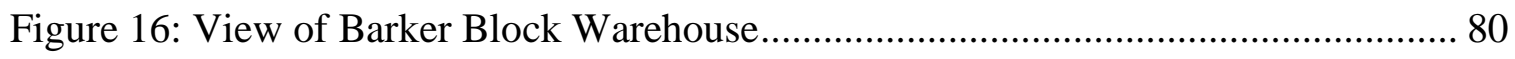

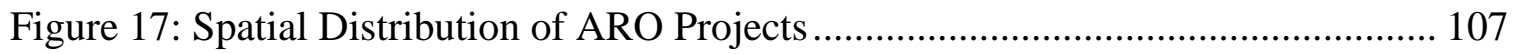

Figure 18: Spatial Distribution of ARO Projects (ARO Incentive Areas)..................... 108

Figure 19: Spatial Distribution of ARO Projects (Community Plan Areas).................. 109

Figure 20: ARO Projects and New Development Permits......................................... 111

Figure 21: New Development Permits in Proximity to Transit .................................... 112

Figure 22: ARO Projects in HQTAs and TPAs .................................................... 115

Figure 23: ARO Projects Inside Higher-Intensity Land Use Districts ......................... 119

Figure 24: ARO Projects and New Development Inside Regional Centers .................. 120

Figure 25: ARO Projects and New Development Inside Community Centers.............. 121 


\section{INTRODUCTION}

\subsection{The Los Angeles Adaptive Reuse Ordinance}

The Los Angeles Adaptive Reuse Ordinance (ARO) is an incentive program intended to encourage the reuse of older buildings that are vacant or not economically viable in their current use. Incentives are designed to streamline the regulatory process and allow flexibility in meeting zoning and building code standards (Bell, 2014; Los Angeles Department of City Planning, 2014d; Mayor's Office of Economic Development, 2004). The ARO was initially developed in 1999 as a strategy to reduce building vacancies in Downtown Los Angeles, an issue that had plagued the area for decades (Bell, 2014; Los Angeles Department of City Planning, 2014d). Facilitating the conversion of vacant space to residential uses was presumed to assist in the area's revitalization, as downtown lacked a residential population base necessary in maintaining a functional urban area (Bell, 2014). Following the success of the ARO in Downtown Los Angeles, the ordinance was expanded to four other areas of the city in 2003 (Mayor's Office of Economic Development, 2004, p. 49). Since its adoption in 1999, the ARO has facilitated residential conversions in 155 historic and existing buildings, creating approximately 13,361 dwelling units. ARO projects in the development pipeline will provide for an estimated 1,620 dwelling units within Downtown Los Angeles alone (Downtown Center Business Improvement District, 2014).

\subsection{Why Adaptive Reuse?}

"Cities need old buildings so badly it is probably impossible for vigorous streets and districts to grow without them (Jacobs, 1961, p. 187)." 
Adaptive reuse can simply be described as the act of converting an existing building to support a new use, typically a use that the building was not originally designed for. Adaptive reuse serves as an effective historic preservation tool. In the context of city planning, the importance of historic preservation cannot be understated. Preserving historical, architectural, and cultural heritage benefits the city in profound ways.

In her landmark book The Death and Life of Great American Cities, the late Jane Jacobs devotes a chapter to describing the benefits of retaining old buildings. This not only includes museum-quality historic landmarks, but low-value older buildings possessing some level of character. Jacobs (1961) described old buildings as a "necessary ingredient in city diversity (p. 190)," quintessential to aesthetic quality and economic vitality. Jacobs believed that both traits are critical to the safety and public life of streets (pp. 188-199). Jacobs discusses the merits of historic preservation mostly in terms of economic diversity. Historic preservation also offers communities with a physical attachment to the people, places, and events of the past. With a global trend in urbanization, it is paramount to preserve this heritage for the enjoyment of future generations.

The social and economic benefits of historic preservation have long been discussed in literature. The environmental benefits have only recently been explored. As issues around climate change have escalated, literature on historic preservation has begun to focus on the interconnections between adaptive reuse and environmental sustainability. Researchers generally agree that adaptive reuse has the potential to accelerate sustainability goals in major cities (Preservation Green Lab, 2011; Yung \& Chan, 2012; Lucuik, Huffman, Trusty, \& Prefasi, 2010; Merlino, 2011; Bullen \& Love, 2010; 
Hasenfus, 2013; Barthel-Bouchier, 2013; Langston, 2008). This includes cities like Los Angeles that have historically struggled with pollution and environmental degradation.

\subsection{Sustainability and Adaptive Reuse}

Building reuse can be considered a holistic approach to sustainable development, as it offers environmental, economic, and social benefits. Building reuse avoids the harmful environmental impacts associated with demolition and reconstruction, and it retains the embodied energy spent producing a building (Preservation Green Lab, 2011, p. 20; Yung \& Chan, 2012, p. 352; Lucuik, Huffman, Trusty, \& Prefasi, 2010, p. 7; Merlino, 2011, pp. 79-80; Moe, 2008; Hasenfus, 2013). Building reuse has been considered an effective tool in supporting smart growth initiatives that lower the demand for suburban development, such as inner-city revitalization (Ryberg-Webster \& Kinahan, 2013; Birch \& Roby, 1984, pp. 199-204; Listokin, Listokin, \& Lahr, 1998; Frey \& Bowdon, 2012). Historic preservation has been documented as a contributor to local economic growth (Ryberg-Webster \& Kinahan, 2013; Bullen \& Love, 2010, pp. 216-217; Birch \& Roby, 1984; Listokin, Listokin, \& Lahr, 1998; Laurie, 2008). Furthermore, historic preservation offers intrinsic social benefits to communities because of the retention of local heritage (Yung \& Chan, 2012, p. 355; Ryberg-Webster \& Kinahan, 2013; Barthel-Bouchier, 2013; Bullen \& Love, 2010, p. 216; Frey \& Bowdon, 2012; Langston, 2008).

However, scholars argue that historic preservation and building reuse can conflict with the goals of sustainable development. It can be difficult to improve the operational efficiency of old buildings and adapt historic buildings to new uses, often because of strict historic preservation standards (Glaser, 2014, p. 139; Barthel-Bouchier, 2013, p. 140; Bullen \& Love, 2010, pp. 218-219; Moe, 2008; Listokin, Listokin, \& Lahr, 1998, 
pp. 460-464; Sohmer \& Lang, 1998, p. 427; Sohmer \& Lang, 1998; The Partnership for Building Reuse, 2014, pp. 31-37). Historic preservation can also restrict urban densification, housing production, and housing affordability (Ryberg-Webster \& Kinahan, 2013, pp. 125-127; Listokin, Listokin, \& Lahr, 1998, p. 460; Stein, 2009, p. 24; Glaeser, 2011, pp. 260-261; Sohmer \& Lang, 1998, p. 429; Been, Ellen, Gedal, Glaesar, \& McCabe; Glaeser, 2010). If historic preservation restricts development in urban areas well served by public transportation, it may impede the potential of land use planning in reducing greenhouse gas emissions. The conflicts between historic preservation and new development will likely escalate as older cities deal with the continuous pressures of growth and modernization.

\subsection{Smart Growth and the Los Angeles Adaptive Reuse Ordinance}

The Los Angeles Municipal Code states that the ARO was intended to "encourage mixed commercial and residential uses in order to improve air quality and reduce vehicle trips and vehicle miles traveled by locating residents, jobs, hotels, and transit services near each other (Los Angeles Municipal Code Sections 12.22-A, 26 \& 12.24-X, 1 as cited in Mayor's Office of Economic Development, 2004)". The ARO would achieve these goals by facilitating residential conversions in vacant older buildings within the downtown core and in commercial and industrial centers poised for redevelopment (Mayor's Office of Economic Development, 2004, pp. 22, 51). Research indicates the ARO reduced building vacancies, increased residential uses, commercial uses, and property values in Downtown Los Angeles (Bell, 2014; Los Angeles Department of City Planning, 2014d; The Partnership for Building Reuse, 2013, pp. 6, 26, 39; Bullen \& Love, 2009, pp. 355-358). The effectiveness of the ARO in reducing vehicle trips is not 
well documented. Researchers claim that the ARO helped to reduce vehicle miles travelled specifically by helping to revitalize Downtown Los Angeles, an area wellserved by heavy and light rail transit systems. However, statements regarding the ARO's role in reducing vehicle miles travelled are not supported by quantitative data and analysis. Research also does not address if the ARO acted as a catalyst for infill development in Downtown Los Angeles, nor does it discuss the location of ARO projects in relation to transit.

A key principle of the smart growth movement is to concentrate urban growth in walkable distances to transit as a way to promote sustainable development (Krueger \& Gibbs, 2008). Encouraging transit-oriented growth is a fundamental strategy in reducing a city's greenhouse gas emissions. This research aims to better understand the interface between sustainable development and building reuse, specifically by examining if the ARO contributed to transit-oriented growth in Los Angeles.

\subsection{Research Objectives}

Dense development in transit-oriented areas is encouraged and incentivized by the City of Los Angeles and the Southern California Association of Governments (SCAG) as part of the regional strategy to reduce greenhouse gas emissions from travel. It is possible that in certain cases, larger buildings with a greater number of dwelling units and commercial space could take the place of buildings reused with ARO assistance. In this context, if the buildings protected by preservation guidelines and receiving ARO assistance are lower density than those that might replace them, than the ARO could have served to constrain the regional goal to reduce greenhouse gas emissions, which would have been attained by increasing land use density and intensity in areas adjacent to Metro 
stations. In contrast, the ARO could have increased infill development in areas adjacent to Metro stations, especially in Downtown Los Angeles where the majority of ARO projects are located. Because the ARO increased downtown's residential population, it could have spurred greater development interest in the area, potentially accelerating infill projects on underutilized sites. If this is the case, the ARO could be characterized as an exemplar strategy of promoting sustainable, transit-oriented growth.

The purpose of this research is to examine the relationships between smart growth, sustainable development, and the Los Angeles Adaptive Reuse Ordinance. This research also aims to contribute to the knowledge of how building reuse contributes to, or detracts from, sustainable urban development, specifically within the context of transit-oriented growth. To examine the ARO's potential contribution to transit-oriented growth, two methods of analysis will be used. The first will determine the number of ARO projects located within a half-mile radius of Metro stations. The second will examine how the ARO has affected development activity in the Central City area, the most transit-rich area of Los Angeles that also houses the highest concentration of ARO projects. The following questions will be addressed in this research:

1. Has the Los Angeles Adaptive Reuse Ordinance contributed to transit-oriented growth?

2. Has the Los Angeles Adaptive Reuse Ordinance had an impact on development activity in the Central City area? Has it increased or decreased overall development activity?

3. Can building reuse serve as a more sustainable alternative than new construction to achieve the goals of smart growth? 


\section{LITERATURE REVIEW}

\subsection{Adaptive Reuse and Sustainability}

There is a growing consensus among researchers and practitioners that historic preservation and adaptive reuse furthers the goals of smart growth and sustainable development. Building reuse avoids the environmental impacts from the demolition and construction process, conserves the embodied energy of materials, promotes energy efficiency, and helps to revitalize aging urban areas.

\subsubsection{Embodied energy and avoided environmental impacts}

Research indicates that adaptive reuse can be a more environmentally sustainable alternative to building demolition and new construction. The environmental value of building reuse is commonly quantified in research using two approaches: the embodied energy approach and the avoided environmental impacts approach (Preservation Green Lab, 2011; Lucuik, Huffman, Trusty, \& Prefasi, 2010; Hasenfus, 2013). The embodied energy approach measures the initial energy investment that has been spent producing a building; it includes the initial energy needed for material manufacturing, transportation, and installation (Preservation Green Lab, 2011, p. 20). The avoided impacts approach measures environmental impacts avoided by reusing a building rather than demolishing and constructing a new building. Examples of impacts avoided through building reuse include the carbon expended from material manufacturing and construction, material and construction waste sent to landfills, and hazardous materials disturbed through building demolition (Preservation Green Lab, 2011, pp. 20, 32; Yung \& Chan, 2012, p. 1; Lucuik, Huffman, Trusty, \& Prefasi, 2010, p. 7; Bullen \& Love, 2010, p. 216). 
Both the embodied energy and avoided impacts approaches demonstrate the environmental savings associated with building reuse. According to a report published in 1979, approximately 80 billion BTUs of energy are embodied in a typical 50,000 squarefoot commercial building, the equivalent of 640,000 gallons of gasoline. Demolishing the same 50,000 square-foot building would result in an estimated 4,000 tons of waste (Advisory Council on Historic Preservation, 1979 as cited in Preservation Green Lab, 2011, p. 20). A 2008 study found that if an existing building was demolished and a more energy efficient building was constructed in its place, it would take between 35 and 50 years for the building to overcome the embodied carbon expended from the initial construction process (Empty Homes Agency, 2008 as cited in Preservation Green Lab, 2011, p. 21). In other words, new buildings make up for their embodied energy costs only several decades after construction (Ireland, 2008, p.4).

A more comprehensive iteration of the avoided environmental impact approach is the life-cycle assessment (LCA) approach. LCA evaluates the environmental and human health related impacts associated with products and services throughout their life cycles, from material extraction to disposal (Preservation Green Lab, 2011, p. 22). A 2011 study using LCA methodology concluded that it takes 10 to 80 years for a new building $30 \%$ more energy efficient than the average historic building to overcome environmental impacts associated with demolition and construction (Preservation Green Lab, 2011, p. 6). Similar LCA based studies support the conclusion that new buildings, including those built for optimal efficiency, will not overshadow the environmental benefits of building reuse (Lucuik, Huffman, Trusty, \& Prefasi, 2010). Besides the embodied energy saved and environmental impacts avoided through building reuse, older buildings often have 
longer life spans and are more energy efficient than modern buildings, providing another reason for their retention.

\subsubsection{Energy efficiency}

Historic buildings are often considered to be less energy efficient than contemporary buildings. However, data from the U.S Energy Information Agency suggests that commercial buildings constructed prior to 1920 use less energy per-square-foot than those constructed at any time before 2000 (Moe, 2008; Merlino, 2011, p. 10; Frey \& Bowdon, 2012, p. 2; Preservation Green Lab, 2011, p. 18). In 1999 the General Services Administration performed an audit on its buildings inventory and found that historic buildings have $27 \%$ less utility costs than modern buildings (Moe, 2008). Historic buildings use less energy for heating and cooling than their modern counterparts because of passive building design (Preservation Green Lab, 2011, p. 18; Frey \& Bowdon, 2012, p. 2; Moe, 2008; Merlino, 2011). Because many historic buildings were constructed prior to the advent of powered lighting, heating and cooling systems, they are designed to take advantage of natural daylight, ventilation, and solar orientation (Frey \& Bowdon, 2012,

p. 2; Merlino, 2011). These buildings typically feature operable windows and thick walls with a high degree of thermal massing. In addition, historic buildings were typically constructed with traditional building materials - concrete, wood, glass - that can have a longer lifespan than contemporary building materials, if properly maintained (Merlino, 2011, p. 10).

On an individual building level, adaptive reuse can be more environmentally friendly than new construction. On a larger scale, building reuse can be more effective than new development in advancing citywide or regional goals to reduce carbon emissions. 


\subsubsection{Urban revitalization and smart growth}

The adaptive reuse of underutilized buildings can be an important tool to support smart growth initiatives, such as inner-city revitalization, infill development, and brownfield redevelopment. Ryberg-Webster and Kinahan (2013) offer an extensive literature review of historic preservation's role in urban revitalization, specifically describing how historic preservation can spur economic development and housing production. Scholars have suggested that historic preservation based-initiatives have achieved greater success in revitalization than urban renewal strategies that often involved raising old neighborhoods (Birch \& Roby, 1984, pp. 45-46; Listokin, Listokin, \& Lahr, 1998, p. 455).

Historic buildings are often located in areas with easy access to public transit, because many were constructed before the widespread use of the automobile. According to the American Housing Survey (1999), 59\% of all residents living in a historic neighborhood have easier access to transit, and $42 \%$ are within five miles of their work (Gilderbloom, Hanka, \& Ambrosius, 2009). Building reuse in these locations lowers demand for development on the urban fringe, thereby helping to reduce vehicle miles traveled and the environmental impacts associated with greenfield development (Frey \& Bowdon, 2012). Several cities (notably Portland Oregon) have recognized this benefit and made adaptive reuse an integral part of their smart-growth oriented infill development and affordable housing strategies (Schilling, 2002, pp. 3-19). In addition, the adaptive reuse of brownfield sites may help to reduce sprawl, because residents who live near blighted, contaminated buildings sometimes relocate to the suburbs (Paulus, 2001, p. 7). The bulk of research recognizing the connection between environmental sustainability and historic 
preservation is somewhat new. Research has long recognized the connections between historic preservation, economic sustainability, and social sustainability.

\subsubsection{Cultural heritage and sense of place}

Historic preservation is widely regarded as a critical measure in retaining community heritage and fostering sense of place. Researchers have suggested that historic preservation meets underlying social and cultural themes of sustainable development by enhancing social inclusiveness and cohesion (Yung \& Chan, 2012, p. 355; BarthelBouchier, 2013; Bullen \& Love, 2010, p. 216). Cultural sustainability, albeit difficult to define, is achieved from the preservation of urban landscapes that provide a sense of continuity with the past. Historic resources, whether it is a building, district, or streetscape, allow communities to have a tangible connection with their heritage. Furthermore, historic preservation helps to retain the character of an urban area that attracts new residents, visitors, and businesses.

Researchers have examined how the place value of historic environments contributes to economic and community development (Ryberg-Webster \& Kinahan, 2013, p. 7; Bullen \& Love, 2010, pp. 216-217; Birch \& Roby, 1984, pp. 199-204; Listokin, Listokin, \& Lahr, 1998, pp. 454-455). Listokin, Listokin and Lahr (1998) argue that historic preservation contributes to urban revitalization largely because of heritage tourism, which helps to spurs economic development (pp.440-444, 451-459). In addition, it has been documented that historic preservation helps to stimulate the local economy more than new construction, because the labor and materials required for restoration and rehabilitation tend to come from local sources (Gilderbloom, Hanka, \& Ambrosius, 2009, 
p. 85; Frey \& Bowdon, 2012, p. 4; Listokin, Listokin, \& Lahr, 1998, p. 444; Shipley, Utz, \& Parsons, 2006, pp. 516-517).

Research suggests that historic neighborhoods have greater economic, cultural, and social vitality than newer areas with larger buildings (The Partnership for Building Reuse, 2014, pp. 18-21; Preservation Green Lab, 2014, pp. 3-4). Older neighborhoods with smaller buildings in Seattle, Washington DC, and Baltimore were found to have an abundance of small businesses, non-chain restaurants and retailers, and creative jobs (The Partnership for Building Reuse, 2014, pp. 18-21; Preservation Green Lab, 2014, pp. 3-4). It has also been argued that historic neighborhoods have safer, more pedestrian-friendly environments (Langston, 2008, p. 9; Preservation Green Lab, 2014, p. 3), although this claim has sparked debate (Ryberg-Webster \& Kinahan, 2013, p. 131). However, a 2014 study determined that older urban areas have higher walkability scores than areas primarily composed of new, large buildings (Preservation Green Lab, 2014, pp. 3-4). Gilderbloom (2009) argues that historic neighborhoods house healthier, more physically active residents, because a high-percentage are located in close proximity to essential amenities and places of recreation (p. 92).

\subsection{Adaptive Reuse: Sustainability Conflicts}

There is an extensive body of research examining how historic preservation and adaptive reuse contributes to sustainability. However, scholars assert that historic preservation and adaptive reuse can conflict with sustainability goals. It can be difficult to reuse or retrofit historic buildings, and historic preservation can impede smart growth initiatives, including urban densification. 


\subsubsection{Difficulty in retrofitting and rehabilitating historic buildings}

Researchers conclude that it can be difficult to improve the operational efficiency of older buildings, largely because of historic preservation standards (The Partnership for Building Reuse, 2014, p. 33; Moe, 2008; Bullen \& Love, 2010, pp. 218-219; Merlino, 2011, pp. 31-51; Barthel-Bouchier, 2013, pp. 139-140). For example, adding insulation and replacing windows to increase a building's energy efficiency can conflict with historic preservation standards (The Partnership for Building Reuse, 2014, p. 33). Historic preservation standards can also conflict with renewable energy technologies, such as wind and solar, which are often viewed as disruptive to a building's historic integrity (Glaser, 2014, p. 139; Barthel-Bouchier, 2013, p. 140; Bullen \& Love, 2010, pp. 218-219; The Partnership for Building Reuse, 2014, p. 33). Green building design presents challenges for maintaining the integrity of historic districts as well as individual buildings. The construction of new green buildings in historic districts could be viewed as incompatible with the character of the district (Stein, 2009, p. 19).

Even sensitive adaptive reuse projects can be a complicated because of historic preservation standards. Some preservationists strongly oppose any renovation activity on historic buildings (Barthel-Bouchier, 2013, p. 140), even if the renovation alters the building in very modest ways (Shipley, Utz, \& Parsons, 2006, pp. 514-516). In some cases, preservationists oppose mandatory alterations because they may compromise historic features (Listokin, Listokin, \& Lahr, 1998, pp. 460-464; Sohmer \& Lang, 1998, p. 427). For example, codes may require contemporary circulation and accessibility alterations, such as the installation of elevators or fire escapes that could detract from 
historic integrity (Shipley, Utz, \& Parsons, 2006, p. 514; Cantell, 2005, p. 18; Yung \& Chan, 2012, p. 359; Listokin, Listokin, \& Lahr, 1998, pp. 460-464).

In addition, attempts to construct additions to historic buildings (often pursued by developers to capitalize on the reuse investment) are often denied by heritage committees (Cantell, 2005, p. 18). There are conflicting theories among preservationists whether additions should remain harmonious with the historic building in scale, proportion and materials, or if additions should be representative of contemporary architectural design (Cantell, 2005, p. 18). As a result of rigid standards, many developers have antagonistic attitudes towards heritage committees and preservationists (Shipley, Utz, \& Parsons, 2006, pp. 514-516). Encouraging greater building reuse may require fundamental changes in the way planners and preservations consider value and significance (Merlino, 2014, p. 85).

Historic preservation standards can limit the ability of an individual building to adapt to modern conditions. The scope of this argument can be expanded to a district, citywide, or even regional scale. Taken from a wider context, historic preservation can limit the ability of an urban area to responsibly absorb and accommodate growth.

\subsubsection{Historic preservation impeding development}

Critics have argued that historic preservation can impede affordable housing development (Ryberg-Webster \& Kinahan, 2013, pp. 125, 127; Listokin, Listokin, \& Lahr, 1998, p. 460; Stein, 2009, p. 24; Glaeser, 2011, pp. 260-261; Sohmer \& Lang, 1998, p. 429). Edward L. Glaeser, a professor of Economics at Harvard University, has written extensively on the subject of historic district designation impeding housing development in New York City. Glaeser argues that historic preservation has frozen large 
tracts of land in New York from development, rendering the city unable to accommodate thousands of potential residents who cannot afford market-rate housing (Glaeser, 2010)

A 2014 report Glaeser co-authored found that after historic district designation, the number of new housing units constructed per year dropped by an average of 14 units in historic districts in New York City as a whole, and by 22 units in Manhattan (Been, Ellen, Gedal, Glaeser, \& McCabe, 2014, p. 22). The report also found that designation has a negative effect on property values, specifically in lower-density areas that could be redeveloped at higher-density levels (Been, Ellen, Gedal, Glaeser, \& McCabe, 2014, pp. $3,14)$. Authors conclude by stating that when taken to the extreme, "historic preservation could limit a city's ability to grow and adapt to the needs of an increasingly competitive global system of cities (Been, Ellen, Gedal, Glaeser, \& McCabe, 2014, p. 2).”

Glaeser's critiques of historic preservation cannot be applied to many other American cities, because few share New York's geographic constraints and high land values. However, critics warn that historic preservation can generally hinder affordable housing development, regardless of the city's physical and economic characteristics (Listokin, Listokin, \& Lahr, 1998, p. 431; Ryberg-Webster \& Kinahan, 2013, p. 125; Sohmer \& Lang, 1998, p. 427). Adaptive reuse projects involving affordable housing production have sometimes been considered infeasible because of the expenses incurred through compliance with strict historic preservation standards and regulations (Listokin, Listokin, \& Lahr, 1998, pp. 460-464; Ryberg-Webster \& Kinahan, 2013, p. 125). As noted by Sohmer and Lang (1998), historic preservation standards for authenticity can sometimes clash with a community's demand for affordable housing development (p.427). Historic preservation standards typically limit the ability to alter a designated historic resource, 
which complicates the construction of additions or renovations. Listokin (1998) states that numerous studies indicate that neighborhood revitalization fostered by historic district designation can contribute to gentrification, resulting in the displacement of area residents (pp.464-467). However, literature indicates that more research is needed to examine historic preservation's role in tenant displacement and neighborhood affordability (Ryberg-Webster \& Kinahan, 2013, p. 131; Byrne, 2012).

Researchers have specifically stated that preservation can thwart planning efforts to increase density in key locations, such as areas in close proximity to public transportation lines (Stein, 2009, p. 24). There are many instances of historic preservation clashing with transit-oriented development, although research on the subject is lacking. A recent example is an area close to Grand Central Station in Manhattan. The New York City Department of City Planning has proposed to upzone a five-block area along the Vanderbilt Corridor to maximize development close to Grand Central Station. Preservationists are deeply concerned that this will result in the demolition of designated historic buildings, and many have organized to fight the proposal (Greenberg, 2015).

It is difficult to determine if the benefits of historic preservation and building reuse outweigh the disadvantages. This determination is highly dependent on unique circumstances specific to an individual city or region. Although this is an important debate to have, one should note that it is often very difficult to reuse a building in the first place. Building reuse is a complicated and difficult activity in cities across the board, those that are prosperous and those that are distressed. 


\subsection{Constraints to Adaptive Reuse}

Building reuse can be a daunting task for the development community. There are common barriers that inhibit building reuse, despite the unique conditions of individual buildings. Through the use of structured interviews with experts on the subject (builders, developers, planners, architects, preservationists), researchers have identified common barriers to building reuse, and potential methods that can be used to overcome those barriers (Austin, 1988; Cantell, 2005; Yung \& Chan, 2012; Curtis, 2008; Bullen \& Love, 2009; Shipley, Utz, \& Parsons, 2006; The Partnership for Building Reuse, 2014). Commonly identified barriers to building reuse include financial risk, lengthy regulatory processes in complying with zoning and building codes, and issues related to structural rehabilitation and the treatment of historic features (Austin, 1988; Cantell, 2005; Yung \& Chan, 2012; Curtis, 2008; Bullen \& Love, 2009; Shipley, Utz, \& Parsons, 2006; The Partnership for Building Reuse, 2014).

\subsubsection{Financial risk}

Researchers have acknowledged that a key hurdle to adaptive reuse is financial risk, which is generally higher and more difficult to predict than new development projects (Cantell, 2005, pp. 3, 14, 26-27; Yung \& Chan, 2012, p. 357; Shipley, Utz, \& Parsons, 2006, pp. 511-512; The Partnership for Building Reuse, 2014). Significant costs may be incurred during the reuse process because of a variety of reasons, including strict historic preservation requirements, structural decay, compliance with building codes, lack of qualified labor, and lengthy review processes. Depending on the condition of the building, the cost of reuse can be enormous. It has been reported that adaptive reuse 
projects can cost almost twice as much as constructing a new building (Shipley, Utz, \& Parsons, 2006, pp. 511-512).

A new use can also sometimes not be profitable enough to cover the cost of reuse. Many developers claim that adaptive reuse projects are only conducive to residential conversions, because residential sales are the quickest, easiest, and most profitable way of dealing with cost overheads (Cantell, 2005, p. 3). If a new use cannot financially sustain itself into the future, the building will eventually be returned to an obsolete condition (Yung \& Chan, 2012, p. 357).

\subsubsection{Building codes}

Contemporary building code regulations (e.g., parking, fire/safety and handicap accessibility regulations) are widely considered as not flexible enough in permitting adaptive reuse projects (Shipley, Utz, \& Parsons, 2006, pp. 514-516; Cantell, 2005, p. 15; Yung \& Chan, 2012, p. 357; Listokin, Listokin, \& Lahr, 1998, p. 471; The Partnership for Building Reuse, 2014, p. 31). Builders and developers have specifically stated that complying with modern building codes is one of the most challenging aspects of adaptive reuse projects (Shipley, Utz, \& Parsons, 2006, pp. 514-516; Cantell, 2005, p. 15; Bullen \& Love, 2010, p. 218). Many older buildings are not compliant with contemporary building codes because they were constructed prior to code enactment. Standard building codes are primarily intended for new construction; they generally have few exceptions for existing buildings (Cantell, 2005, p. 15; Bullen \& Love, 2010, p. 218; Yung \& Chan, 2012, p. 355). Yung and Chan (2012) have noted that many historic buildings are lacking in sanitary and fire protection elements, which complicates any project involving renovation and reuse (p.357). Building code compliance is even more complicated if the 
building is a designated historic resource. The addition of elements mandated by contemporary building codes (for example, elevators or fire escapes) could harm the appearance and integrity of historic buildings (Shipley, Utz, \& Parsons, 2006, pp. 514516; Listokin, Listokin, \& Lahr, 1998, p. 462).

\subsubsection{Zoning codes}

Zoning codes can also complicate adaptive reuse projects. Minimum parking requirements can make it difficult or even infeasible to reuse buildings that were constructed before parking mandates existed. If a historic building lacks on-site parking spaces, developers are forced to alter the building to provide for parking spaces, or they must provide off-site parking spaces in the form of a lot or structure (Frey \& Bowdon, 2012, p. 9; The Partnership for Building Reuse, 2014, p. 31). This is especially problematic in older urban areas with a high demand for parking. Alterations to a historic building can harm integrity, and the construction of parking structures adjacent to historic districts can be viewed as incompatible with the character of the historic district.

In addition, zoning codes may disallow adaptive reuse if the new use is not compatible with existing zoning. For example, the underlying zoning designations of many jurisdictions does not allow residential or commercial uses in buildings formerly used for industrial purposes (Cantell, 2005, p. 14). A conditional use permit may be required if the proposed new use is incompatible with the zoning designation.

\subsubsection{Regulatory processes}

Another constraint to adaptive reuse is the entitlement process typically involved in obtaining permits for an adaptive reuse project (Yung \& Chan, 2012, pp. 357-358; Shipley, Utz, \& Parsons, 2006, pp. 516-517; Listokin, Listokin, \& Lahr, 1998, pp. 461- 
464; The Partnership for Building Reuse, 2014, p. 33). Adaptive reuse projects often require extra levels of review from regulatory agencies. The majority of experts interviewed by Yung and Chan (2012) identified long review periods as a challenge that usually incurs extra costs (pp. 357-358). One preservation-specialist architect estimated that regulatory review adds an additional $30 \%$ to the cost of the project, and doubles the time needed for completion (Yung \& Chan, 2012, p. 357).

Interviewees from the Shipley (2006) study argued that the timing of building inspections was problematic, and that there is a lack of coordination among inspectors from various regulatory agencies, which burdens the development process (p. 515). The development process is more prolonged and expensive if the project requires a special permit to allow for exemptions from zoning regulations. If the project requires a variance or a conditional use permit, it will trigger a planning review process, and in the end the project may not be approved (Cantell, 2005, p. 14; The Partnership for Building Reuse, 2014, pp. 34-35, 46-50). If the project involves the reuse of a designated historic building, historic preservation specialists must review the project to ensure that the integrity of historic features are not compromised. Researchers agree that historic preservation review is a long and expensive process that can result in significant unforeseen expenditures (Listokin, Listokin, \& Lahr, 1998, pp. 461-464; Shipley, Utz, \& Parsons, 2006, p. 514; The Partnership for Building Reuse, 2014, p. 33; Brown, 2009, pp. $28-29,47-49,65)$.

In the United States, adaptive reuse projects have been complicated because of the Secretary of the Interior's Standards for the Treatment of Historic Properties - historic building renovation and rehabilitation standards developed by the National Park Service. 
These standards are intended to guide the sound treatment of historic buildings, and they are used by the federal government, state, and local governments when reviewing projects that involve rehabilitation, restoration, or renovation of a historic property (National Park Service, n.d.). Complying with these standards has sometimes resulted in setbacks and delays in obtaining permits necessary for adaptive reuse projects (Brown, 2009, pp. 28-29; Cantell, 2005, p. 22).

\subsubsection{Design/structural constraints}

Building design characteristics and structural issues may impede the feasibility of adaptive reuse. Many older buildings are in poor condition or feature obsolete design characteristics, which can result in unexpected costs to the developer (Shipley, Utz, \& Parsons, 2006, pp. 513-514; Cantell, 2005, p. 18; The Partnership for Building Reuse, 2014, pp. 31-33; Langston, 2008, p. 9). Historic building arrangements, such as low ceiling heights, make many buildings functionally obsolete for contemporary new uses (Cantell, 2005, p. 18). To account for unexpected costs, most reuse projects require a detailed analysis prior to development to determine the building's opportunities and constraints (Cantell, 2005, p. 18). However, costs are sometimes difficult to predict. For example, historic artifacts have sometimes been discovered inside building walls and floors, driving up project cost because of documentation (Brown, 2009, p. 65)

Because many older buildings are located on brownfield sites, remediating contamination can also drive up the cost of reuse (Shipley, Utz, \& Parsons, 2006, pp. 513-514; The Partnership for Building Reuse, 2014, p. 30). In addition, buildings that have sat vacant for long periods of time are often in disrepair and require extensive 
seismic and structural renovations, significantly adding to project cost (Cantell, 2005, p. 20; The Partnership for Building Reuse, 2014, p. 30; Flynn, 2007, p. 131).

\subsection{Methods Used to Incentivize Adaptive Reuse}

There are a number of common factors that hinder adaptive reuse. However, there are measures that local governments have taken to overcome these constraints, including flexible building codes, zoning codes, and incentive programs.

\subsubsection{Flexible building and zoning codes}

Researchers have identified flexible building and zoning codes as a key strategy to facilitate building reuse (Listokin, Listokin, \& Lahr, 1998, p. 471; The Partnership for Building Reuse, 2014, p. 6; Frey \& Bowdon, 2012, p. 9; Cantell, 2005, pp. 14-17;

Schilling, 2002, p. 7). Alternative code standards tailored to adaptive reuse could optimize the benefits of historic preservation. Listokin, Listokin and Lahr (1998) suggests that if building codes were made more flexible for building reuse, it could bolster historic preservation's role in contributing to housing development and economic growth (p.471). Flexible codes could also encourage greater building reuse in cities that are struggling with vacant or obsolete buildings (Schilling, 2002, p. 7).

Several states already use alternative building codes designed for adaptive reuse. Examples of alternative codes include the California Historical Building Code and the New Jersey State Rehabilitation Code. Both codes have regulations and standards in place that give property owner's flexibility in adaptive reuse while meeting historic preservation standards (Cantell, 2005, pp. 16-17). City governments have also relaxed standard zoning code requirements to encourage building reuse. Los Angeles, Tacoma, and San Francisco have enacted ordinances that exempt reuse projects from meeting 
minimum parking requirements (Frey \& Bowdon, 2012, p. 9). Additional solutions used to circumvent zoning barriers include mixed-use zones, special preservation districts, and form-based codes (Cantell, 2005, pp. 14-17).

\subsubsection{Adaptive reuse programs/polices}

Municipalities across the United States have adopted programs to encourage building reuse. These programs use a variety of incentive methods, including a streamlined approval process and relief from regulatory standards. Examples of cities that have adopted comprehensive adaptive reuse programs include Los Angeles, California, Phoenix, Arizona, and Corpus Christi, Texas.

The Phoenix Adaptive Reuse Program, adopted in 2008, does the following to facilitate building reuse: 1) gives priority to adaptive reuse projects when processing zoning applications; 2) provides expedited permit reviews by issuing certificates of no effect rather than certificates of appropriateness, and; 3) gives priority to reuse projects when allocating Historic Preservation Bond funds (City of Phoenix Planning and Development Department, 2014). The Corpus Christi Adaptive Reuse Ordinance does the following to facilitate building reuse: 1) waives $50 \%$ of zoning fees for qualifying projects; 2) allows by-right entitlement to skip regulatory review processes, and; 3) does not require minimum parking spaces (City of Corpus Christi Development Services, 2014). It is unclear how effective these ordinances have been because monitoring reports are not available. The Los Angeles Adaptive Reuse Ordinance is frequently cited as an exemplar adaptive reuse program, and there are multiple reports detailing its success (Bullen \& Love, 2009; The Partnership for Building Reuse, 2013; Los Angeles Department of City Planning, 2014d; Mayor's Office of Economic Development, 2004). 


\section{THE LOS ANGELES ADAPTIVE REUSE ORDINANCE}

\subsection{History}

Before 1999, Downtown Los Angeles had endured a long period of decline.

Downtown functioned as the regional central business district from roughly 1890 until the late 1920s, when suburban-driven decentralization shifted commercial activity towards the many newly formed edge cities (Davis, 1992, p.118; Bottles, 1987, pp.14, 32; Longstreth, 1998, p.11). Downtown's waning commercial vitality was generally made worse by highway construction during the 1950s and 1960s, which enclosed the area from the rest of the city on all sides (Shigley, 2009). By the 1960s, downtown offered little in the way of vibrancy, as land uses were primarily industrial and institutional in nature (Shigley, 2009). While redevelopment of the bunker-hill area of downtown during the 1960s until the 1980s replaced declining residential neighborhoods with new glassy skyscrapers, the historic downtown area was essentially left abandoned (Bernstein, 2012, p.253; Shigley, 2009). Merger-and-acquisition activity in the late 1980s led to an exodus of downtown's fortune 500 companies (Shigley, 2009), and in the subsequent decade downtown struggled with millions of square feet of vacant building space (Bernstein, 2012, p.255).

In 1996 a group of property owners, developers, and local politicians began the process of forming an adaptive reuse task force to address the issue of blighted buildings in Downtown Los Angeles (Brown, 2009, p. 25; Bernstein, 2012, p. 257). At the time, much of Downtown Los Angeles's historic building stock had sat vacant for decades, with many buildings falling into disrepair (Bell, 2014; The Partnership for Building Reuse, 2013, p. 6). Local stakeholders were concerned that blighted buildings would 
undermine the goals of proposed development projects intended to revitalize the area, including the Sports Area, Metro Rail stations, and Disney Hall (Brown, 2009, p. 25).

By 1997 an adaptive reuse task force was assembled with the charge of developing recommendations for a regulatory program that would facilitate the reuse of blighted older downtown buildings (Brown, 2009, p. 2). At the time city regulations were inhospitable to adaptive reuse; regulations treated building reuse identical to new construction (Bell, 2014; Bernstein, 2012, p. 257). If an existing building became vacant and obsolete, the owner was often limited to two choices: apply for exceptions from new construction standards, or demolish the building and encourage new development. When faced with this dilemma, many property owners simply left buildings vacant (Bell, 2014). Developers warned the city that such neglect would eventually lead to building demolition (Shigley, 2009).

For close to two years task force members crafted the program framework of the ARO, and in 1999 the ordinance was adopted for the greater downtown area (Brown, 2009, p. 25; Mayor's Office of Economic Development, 2004, p. 19). Program provisions were generally designed to reduce entitlement risks typically associated with adaptive reuse projects. The program streamlined the adaptive reuse process by allowing qualifying projects flexibility in meeting building code and zoning standards, which often eliminated the need for discretionary land use approvals (Bell, 2014; Los Angeles Department of City Planning, 2014d, p. 9; Brown, 2009, pp. 26-27; Mayor's Office of Economic Development, 2004). Flexible building code and zoning standards are applicable to designated historic resources and buildings not eligible for historic resource designation. However, historic resources still require discretionary review because of 
potential impacts to historic features (Mayor's Office of Economic Development, 2004, p. 10). The program also directs staff to help applicants acquire historic preservation financial incentives, including Federal Historic Rehabilitation Tax Credits and incentives offered by the Mills Act (Mayor's Office of Economic Development, 2004, p. 2). Both provide property owners with tax abatement when restoring or rehabilitating a designated historic resource.

\subsection{Technicalities}

The ARO contains two components: the first provides flexibility in meeting zoning requirements; the second provides flexibility in the approval and permitting process (Mayor's Office of Economic Development, 2004, p. 7). Zoning incentives include no minimum parking requirements, grandfathered in non-conforming floor areas, setbacks and heights, flexibility in the construction of mezzanine space, no newly required loading space, and the replacement of density rules with minimum dwelling unit size standards (Mayor's Office of Economic Development, 2004, p. 16; Los Angeles Department of City Planning, 2014d, p. 9).

Under the ARO, if a project meets "by-right" criteria, than the Department of Building and Safety issues a permit and the developer is entitled to develop the project without special city review or environmental review (Mayor's Office of Economic Development, 2004, p. 15). A building meets by-right criteria if it is located in a designated ARO incentive area, if it is located in a commercial or high residential zoning district, if it was constructed before July 1 1974, and if the project includes rental units (Mayor's Office of Economic Development, 2004, p. 10). If the building does not meet this criteria, or if the building is a designated historic resource, than it is subject to 
discretionary review with the City Planning Department. Projects subject to discretionary review require environmental (CEQA) clearance, and program incentives must be approved by either the Zoning Administrator or the Deputy Advisory Agency (Mayor's Office of Economic Development, 2004, p. 10).

If an adaptive reuse project is permitted as by-right, the project sponsor must file an application with the Department of Building and Safety to meet fire and life safety standards, building, mechanical and electrical code requirements, disabled access compliance, and seismic retrofit requirements (Mayor's Office of Economic Development, 2004, p. 10). These standards are designed to fit the needs of older buildings; they are more flexible than standards for new buildings.

During the ARO approval process, the Department of Building \& Safety, the Planning Department, and Fire Department coordinate their efforts to streamline the regulatory process (Los Angeles Department of City Planning, 2014d, p. 9). Provisions have dramatically reduced the time of the permitting process. Before the adoption of the ARO, it would take approximately 30 months to obtain an adaptive reuse building permit. If a developer wanted to convert a commercial building into a residential building, they would endure the long and "torturous process" of having the parcel rezoned, or fulfilling the current parking requirements on a 100-plus year-old building (Brown, 2009, p. 60). With the ARO, it now takes approximately 6 months to obtain the same permit, if the project meets by-right criteria (Los Angeles Department of City Planning, 2014d, p. 9).

\subsection{Success}

From 1999 to 2001 a series of ten amendments and official interpretations have refined the ARO and expanded its geography outside of Downtown Los Angeles to 
include four additional incentive areas (Los Angeles Department of City Planning, 2014d, p. 2). The ARO is now applied to areas within the Hollywood, Mid-Wilshire, Korea Town, China Town, Lincoln Heights, and Central Avenue districts (Brown, 2009, p. 64; Mayor's Office of Economic Development, 2004, p. 9). These areas had typically been zoned and development for a single use, and most had an excess of obsolete or vacant commercial and manufacturing buildings. The ARO permitted mixed-use residential development in these areas without the burden of a large-scale rezoning effort. It has been suggested that the ARO helped obsolete areas become viable once again (Brown, 2009, p. 69).

The ARO was also expanded largely due to its success in Downtown Los Angeles. According to the Los Angeles Department of City Planning (2014), the ARO has created 11,965 dwelling units in Downtown Los Angeles alone (d., p.2). Brown (2009) suggests that without the ARO, these dwelling units would not have been constructed (p.79). Because of the dwelling units created by ARO projects, the ordinance has been credited with increasing the residential population of Downtown Los Angeles. According to the Downtown Center Business Improvement District, between 1999 and 2014 Downtown Los Angeles's residential population increased from 18,700 to 53,915 residents (Downtown Center Business Improvement District, 2014, p. 5). ARO projects under construction or in the development pipeline are estimated to create an additional 1,620 dwelling units in Downtown Los Angeles alone (Los Angeles Department of City Planning, 2014d, p. 11).

Researchers and planners agree that the increase in housing brought from ARO projects helped bring life back into Downtown Los Angeles. The ARO has also been 
described as a contributing factor in the growth of Downtown Los Angeles's property values (Los Angeles Department of City Planning, 2014d, p. 13). Peter Bullen and Peter Love (2009) credit the ARO with facilitating the development of a "24-hour city" in Downtown Los Angeles with a more balanced ratio between housing, jobs, and services (p.357). Besides residential uses, other uses were often permitted as part of ARO projects, including live/work uses, hotels, commercial condominiums, and ground-floor retail stores. Los Angeles Planning Director Alan Bell (2014) states that because the ARO has helped to bring residents closer to their jobs, it has helped to increase public transit ridership, alleviate traffic congestion, reduce vehicle miles travelled, and improve regional air quality.

\subsection{Impediments}

For the most part, the ARO has received widespread acclaim from researchers and practitioners. However, it has also been criticized, mostly from the development community. Developers interviewed by Brown (2009) claimed that after the Riordan administration (post 2001) the ARO has not been as supportive towards developers because the approval process has become less streamlined (p.62). However, as Brown (2009) points out, the approval process likely became less streamlined because more developers began using the program, and because developers began pursuing more projects that did not meet by-right criteria. This resulted in a greater demand for permitting, variances, conditional use permits, and reviews from the Office of Historic Preservation (p.62). The ARO has also been somewhat limited in its scope, as it has primarily been used for residential purposes. The report Learning from Los Angeles (2013) suggested that because the ARO does not allow conversions strictly for 
commercial purposes, it has failed to take advantage in the growing demand for "creative office space" in older, character-rich buildings, especially among start-ups and small creative firms (p.7).

\subsection{Evaluation}

The methodology of this thesis involved the creation of dataset that contains a variety of characteristics for each ARO project. This dataset allowed for a broad evaluation of the ARO. Overall, the ARO has created approximately 13,361 dwelling units in 155 buildings throughout the city (Los Angeles Department of City Planning, 2014d, p. 10). It is difficult to determine how many entire buildings have been reused under ARO assistance. Some projects simply involve conversions to portions of buildings. ARO projects reached their peak level of popularity between 2005 and 2008. Close to $40 \%$ of all projects occurred during this time period. Table 1 below displays average building characteristics for ARO projects. Most projects were moderate in size, typically with five stories and a floor-area-ratio (ratio of building square footage to parcel size) of 3:1. Most had approximately 112 dwelling units, typically with a mix of rental and live/work units.

Table 1: ARO Average Building Characteristics

\begin{tabular}{|c|c|}
\hline Building Characteristic & ARO Projects \\
\hline Average Number of Dwelling Units & 112 \\
\hline Average Number of Stories & 5 \\
\hline Average Building Square Footage & 73,504 \\
\hline Average Floor-Area-Ratio & $3: 1$ \\
\hline Average Year Built & 1931 \\
\hline $\begin{array}{c}\text { Note: } \text { The number of dwelling units was approximated through numbers provided by vesting } \\
\text { tentative tract maps, zoning administrator determinations, and building permits. These different } \\
\text { forms often had conflicting numbers of units, commercial spaces, and parking spaces. }\end{array}$
\end{tabular}


Figure 1: Distribution of ARO Projects in Relation to Incentive Areas

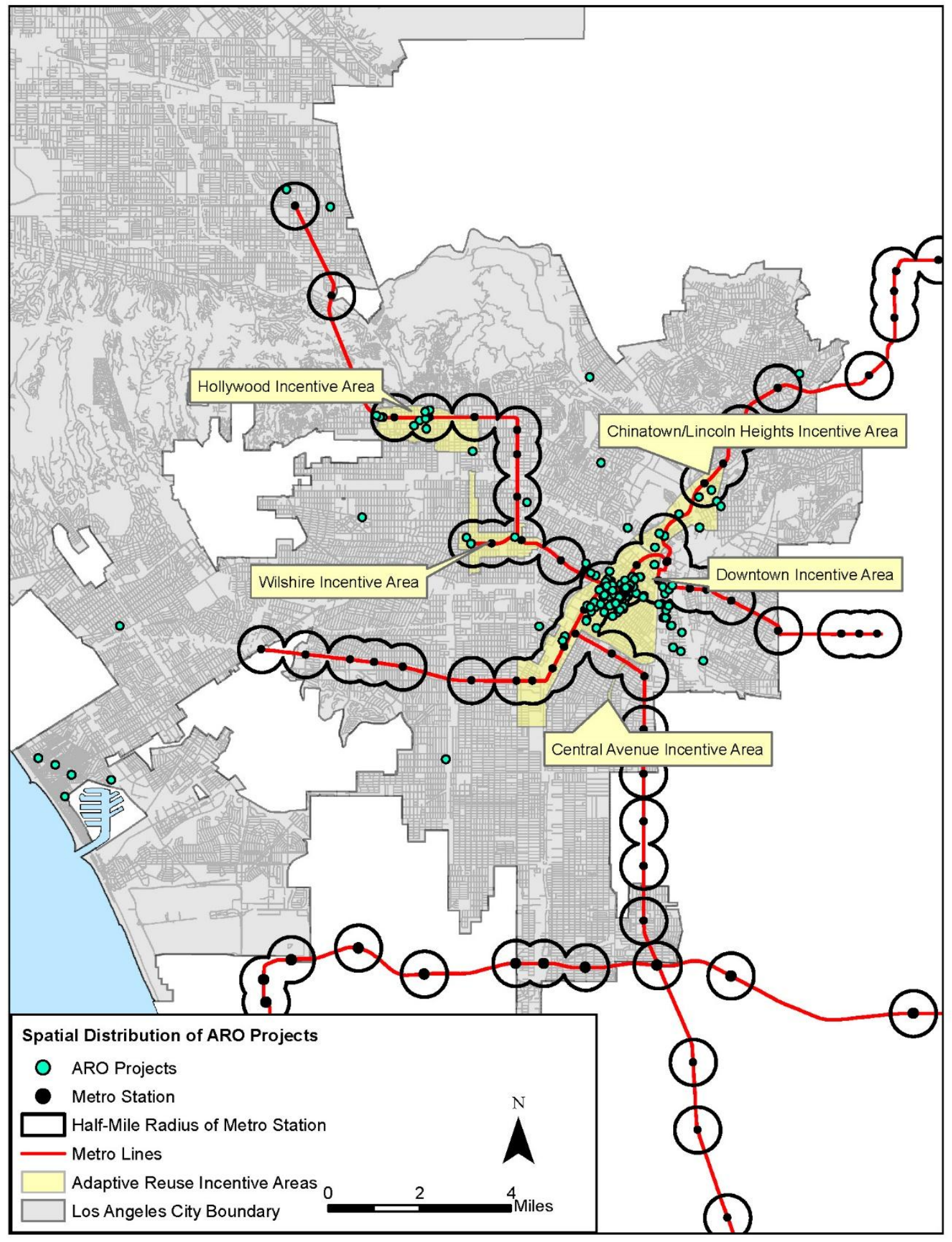




\section{SPRAWL AND SMART GROWTH IN LOS ANGELES}

\subsection{Sprawl and Auto Dependency in Los Angeles: A Historical Context}

An overarching goal of the ARO was to help spur the revitalization of incentive areas as a way to reduce vehicle miles travelled (Mayor's Office of Economic Development, 2004, pp. 22, 50-51). Downtown Los Angeles is the nexus point for regional transit four Metro rail lines run through this area. All other incentive areas are adjacent to transit stations. Encouraging greater land use densities and intensities around transit stations, coupled with investments to active transportation systems, has become both city and regional strategies to reduce greenhouse gas emissions. A dense, transit-oriented Los Angeles is a bold new vision for the region. Before describing the transit-oriented development and active transportation strategies currently underway, it is important to first discuss the historical context of Los Angeles's auto-oriented development patterns.

\subsubsection{Streetcar suburbs}

Los Angeles has long been characterized as an auto-dependent city. Automotive travel has been the primary factor that has shaped the urban form of the Southern California region. Before the private automobile gained popularity, Los Angeles County was served by an extensive streetcar system, established in the late 1800s by powerful real estate moguls (Jackson, 1985, p. 122). These entrepreneurs not only constructed the streetcar lines themselves, but also residential neighborhoods adjacent to streetcar lines (Jackson, 1985, p. 122). The streetcar system thus enabled Los Angeles to grow outward from the downtown core, fostering the development of "streetcar suburbs" that would eventually set the momentum for the region's decentralization and sprawl (Bottles, 1987, p. 14; Jackson, 1985, p. 122; Longstreth, 1998, p. 11). 
Figure 2: Map of Los Angeles Streetcar System, 1920 (Smith, 1920).

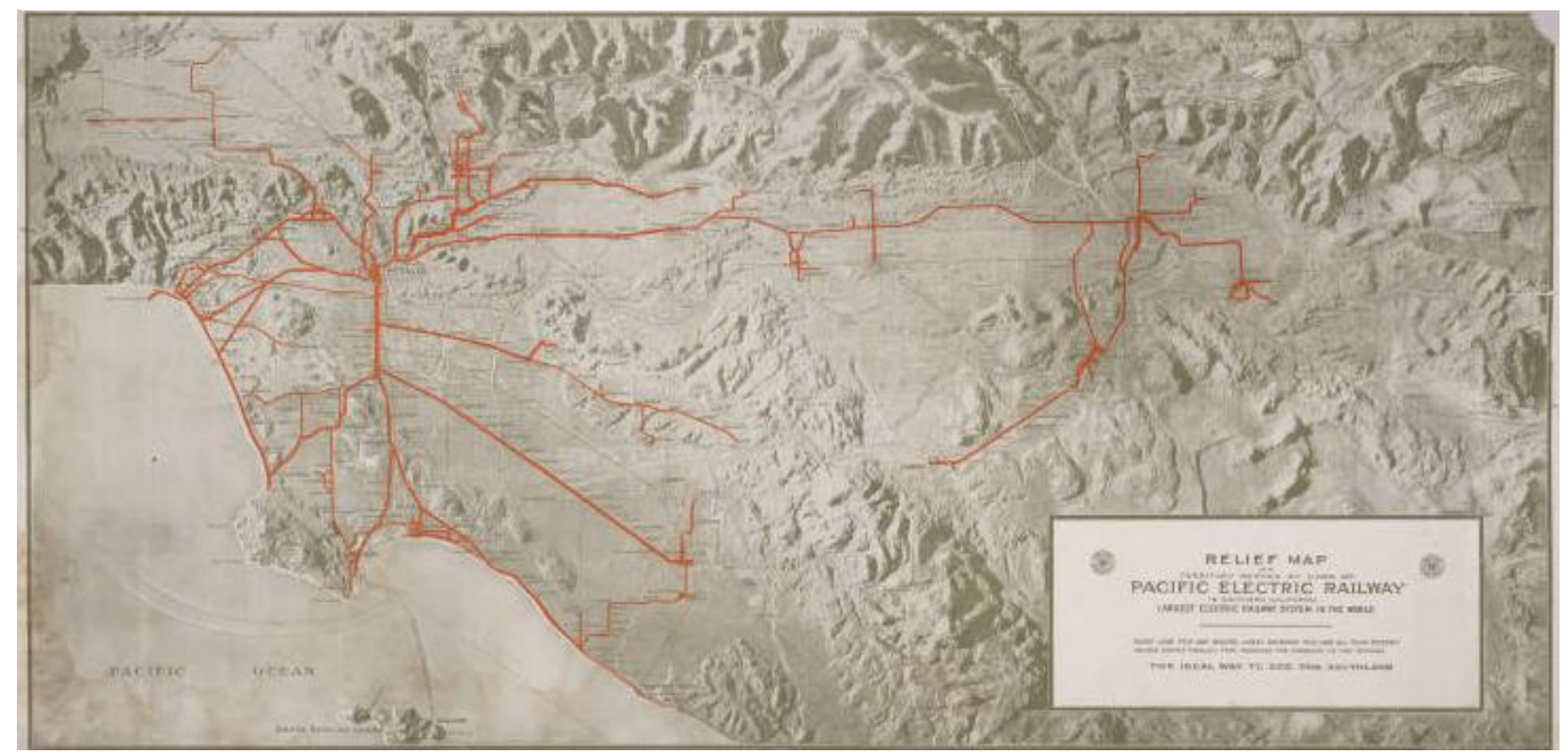

From the late 1880s until the 1920s, the streetcar was the dominant mode of travel for commuters in the Los Angeles region (Bottles, 1987, p. 14; Longstreth, 1998, p. 11).

During this time real estate development was closely associated with the streetcar - most development in the region occurred around streetcar lines (Longstreth, 1998, p. 12). The streetcar suburb is not specific to Los Angeles - this pattern of development characterized historic development trends in virtually every major American city prior to the mass adoption of the automobile. However, few other American cities were altered as dramatically as Los Angeles from the automobile.

\subsubsection{The early proliferation of automobile use}

Private automobile use caught on quickly in the Southern California region. The 1920s marked a departure from the streetcar to the automobile as the dominant mode of travel. From 1918 to 1923 automobile registration in Los Angeles County had increased by fourfold (Bottles, 1987, p. 107). By 1925, there was approximately one car per 1.6 
persons in the region, a level of automobile density that the rest of the nation would not reach until the late 1950s (Davis, 1992, p. 118; Bottles, 1987, p. 93).

As a result of increased automobile use, residential development became more closely associated with the automobile than the streetcar. To keep up with the demand for housing, developers had two options: increase density in built-up areas around railways, or construct housing on the urban periphery, often in areas distant from existing streetcar lines (Longstreth, 1998, p. 12). Developers typically chose the second option. Post 1920, residential development and automobile use had a "symbiotic relationship" resulting in a high percentage of low-density neighborhoods consisting of single-family houses located increasingly further away on the urban periphery (Longstreth, 1998, p. 11).

\subsubsection{Automobile domination}

The number of people commuting by automobile eventually grew to outnumber the number using public transportation (Longstreth, 1998, pp. 16, 99). As automobile use proliferated, there was an increasing conflict between streetcars and motorists for use of the right-of-way. Automobiles exacerbated traffic congestion in Downtown Los Angeles, an area that had already been struggling with streetcar congestion (Bottles, 1987, p. 15; Longstreth, 1998, p. 19). To curb congestion, the city council passed a rigid no parking law in downtown that was met with heavy opposition and protest, forcing the council to quickly repeal the law (Bottles, 1987, p. 16). This was the first of many legislative decisions that entrenched the automobile as the integral component of the regional transportation system. Between 1920 and 1950, highways were constructed, streets were widened, and streetcars lines were demolished, all to accommodate the automobile 
(Longstreth, 1998, pp. 31, 210; Bottles, 1987, p. 20; Jackson, 1985, p. 122). By 1944 the streetcar system was scarcely used (Bottles, 1987, p. 21).

The prioritization of automobiles in the transportation system allowed automobile use to increasingly grow during this time period. As a result, Los Angeles has a whole became more decentralized and suburban in character. Downtown's "central place monopoly (Davis, 1992, p. 118)" was superseded by new automobile-oriented commercial districts located away from the urban core (Longstreth, 1998, p. 11; Davis, 1992, p. 118; Bottles, 1987, p. 20). Most development that occurred during this time period was low-density by nature. Although multi-unit dwellings were constructed, most only contained one to two stories, except for those in specific, concentrated areas (Longstreth, 1998, p. 10).

Automobiles grew to have an even greater influence on land use patterns with the mass construction of freeways following the passage of the 1956 National Defense and Interstate Highway Act. Between 1956 and 1970, a maze of freeways was constructed in the Los Angeles region, further enabling suburban development (Boarnet, 2012, p.150). Low-density sprawl has largely characterized the region's development history. Both the city and region now primarily consists of suburban areas highly dependent on the automobile. Although the automobile exacerbated suburbanization and decentralization, the city had been following this trajectory since the turn of the $20^{\text {th }}$ century when streetcars were the dominant mode of travel. Mobility in a city as decentralized as Los Angeles requires some form of vehicular travel, whether it is by public transit or the automobile. Today, most commuters within the region commute by car, truck, or van (SCAG, 2012, a., p.4). According to the 2008 American Community Survey, less than 
$4 \%$ of the region's population commuted to work via walking or cycling (SCAG, 2012a, p. 4). As Bottles (1987) describes it, Los Angeles has "never existed as a true walking city (p.14).

\subsection{Transit-Oriented Development}

The long-term development of Los Angeles as an automobile-oriented city has had profoundly negative environmental and public health impacts. The region has a reputation for congestion and poor air quality, among other environmental and health issues. In addition, the Los Angeles region emits more greenhouse gases into the atmosphere than most American cities. In 2008 a research team from Purdue University identified Los Angeles County as the second highest carbon-emitting county in the nation, right behind Houston, Texas. Vehicle emissions were determined to be the largest contributor to the county's total carbon emissions (Purdue University cited in Lindsey, 2009). A 2011 study of carbon emissions from ten global cities found Los Angeles to have the second highest total end use emissions (includes electricity, heating and industrial fuel use, transportation, and waste). The same study suggests that these emissions are primarily a result of low-density development patterns (Kennedy, Steinberger, Gasson, Hansen, Hillman, Havranek, Mendez, 2009, pp.7300-7301).

Although issues of automobile dependency still persist, there has been recent momentum in creating a more environmentally friendly and healthy region through transit-oriented development and active transportation planning. Dense development in areas adjacent to transit is a strategy that will provide community benefit while reducing greenhouse gas emissions. Transit-oriented development strategies are being pursued on 
both a regional and local level. Because the ARO was partly devised as a strategy to reduce vehicle miles travelled, it helps to implement these overarching efforts.

\subsubsection{Introduction}

Transit-oriented development offers a number of environmental, economic, and health benefits. Densely populated cities with strong access to public transit emit less carbon than sprawling, low-density cities. A 2006 study found that the most densely populated cities have less private automobile use and lower carbon emissions per capita than the majority of cities in the United States (Dodman, 2009, p. 193). These cities have coordinated land use and transit in a way where it is often more convenient to use transit than to drive. Increasing land use densities close to transit is considered by planners as a key strategy to reduce greenhouse gas emissions. However, it is also simply considered good urbanism. Transit-oriented development is a key component of the new urbanist and smart growth movements. Compact communities with strong access to transit have greater access to jobs and services than sprawling, low-density cities.

Los Angeles has a robust transit system in place, yet it is often characterized as a city that is inherently not transit-oriented. Much of the development that has occurred within the city and region consists of low-density, auto-dependent sprawl. The existing transit network, coupled with proposed investments, creates an enormous opportunity for a more transit-oriented region. $97 \%$ of residents in the SCAG region live within two miles of an existing transit station, and $22.5 \%$ of jobs in Los Angeles County are within a half-mile of existing or proposed transit stations (SCAG, 2012a, p. 22; Center for Transit-Oriented Development, 2010, p. 60). 
Land use densities and intensities can be increased around Metro stations throughout the region. A 2010 study performed by the Center of Transit-oriented Development found that much of the land uses around Metro rail stations consist of vacant and underutilized properties, including small parcels that do not comfortably accommodate development (p.42). The same study concluded that local governments need to better coordinate their land use and implementation strategies to better accommodate commercial and highdensity residential development in station areas (p.81). This will be a challenge in meeting state goals to reduce greenhouse gas emissions from travel.

\subsubsection{SB 375 and Sustainable Communities Strategy}

The Sustainable Communities and Climate Protection Act (SB 375) was enacted in 2008 with the intent of supporting California's climate action goals to reduce greenhouse gas emissions from passenger and light truck vehicle use (California Air Resources Board, 2014). Under SB 375, the California Air Resources board established 2020 and 2035 GHG reduction targets for each urbanized region represented by a Metropolitan Planning Organization (MPO), a federally mandated entity charged with developing regional transportation planning policy (California Air Resources Board, 2014). SB 375 requires each MPO to prepare a "Sustainable Communities Strategy" (SCS), which coordinates land use and transportation planning efforts to produce a per capita reduction in vehicles miles travelled over a 25 year time period (California Air Resources Board, 2014). An SCS essentially merges two regional planning exercises: Regional Housing Needs Allocation and Regional Transportation Plans (Logan, 2013, p. 2).

An SCS does not supersede the land use and transportation authority of local governments within a regional jurisdiction (SB 375, 2008). Cities and counties within 
each MPO region can enact their own land use policies and transportation plans as they see fit. However, local governments are encouraged and incentivized to implement the SCS by coordinating land use and transportation plans with the SCS. Localities are typically incentivized to prepare these plans because of opportunities for various state and federal funding sources (Logan, 2013, p. 2). Developers are incentivized to construct mixed-use development projects consistent with the SCS through relief from environmental review requirements (California Air Resources Board, 2014; SB 375, 2008). All of the MPOs representing major metropolitan regions have adopted an SCS, and each MPO has developed unique planning approaches for implementation (California Air Resources Board, 2014; Logan, 2013, p. 14).

In 2012, the Southern California Association of Governments (SCAG) adopted a \$525 billion Regional Transportation Plan and Sustainable Communities Strategy (RTP/SCS) for the six counties and 191 cities it represents (Logan, 2013, p. 14; SCAG, 2012). The SCAG RTP/SCS outlines a regional transportation plan and land use pattern to meet greenhouse gas reduction targets consistent with SB 375 (SCAG, 2012). The transportation component of the RTP/SCS proposes a variety of improvements to the region's multimodal transportation system, including the expansion of the system to areas where growth is appropriate (SCAG, 2012, p. 4). The land use component of the RTP/SCS proposes that growth should be prioritized in areas well served by public transportation, particularly around transportation nodes and corridors (SCAG, 2012).

\subsubsection{SCAG RTP/SCS overview: land use}

Employment and housing growth is encouraged in the RTP/SCS to primarily occur within the region's designated High-Quality Transit Areas (HQTA) (SCAG, 2012, p. 30). 
HQTAs are described as walkable areas located within a half-mile radius of local and regional transit corridors with frequent service (15 minutes or less) during peak commute hours (SCAG, 2012, p. 130). Almost the entire City of Los Angeles has been defined by SCAG as an HQTA. SCAG Transit Priority Areas differ from SCAG HQTAs. Transit Priority Areas (TPA) are areas within a half-mile of a major existing or planned transit station (SCAG, n.d). SB 743 (signed by Governor Brown in 2013) provides CEQA exemptions and alternative analysis of transportation impacts for projects located within TPAs (OPR, 2014). TPAs in the Los Angeles region are areas located within a half-mile radius of a Metro station.

It is important to note that not all HQTAs and TPAs are targeted for growth (SCAG, 2012, p. 131). Under SB 375 an SCS cannot mandate land use and general plan policies at the local level. It is rather intended to provide cities and counties with land use, transportation, and housing policy guidance on how to help the region achieve greenhouse gas reduction targets (SCAG, 2012, p. 108; California Air Resources Board, 2014). Because the SCAG RTP/SCS was developed primarily with input from local general plans within the region, RTP/SCS land use policies were heavily influenced by local land use policies (SCAG, 2012, p. 119). Many localities within the SCAG region have robust transit-oriented development land use policies and programs in place, while others continue to encourage auto-oriented development (SCAG, 2012, p. 116). Development within the region will likely occur outside of HQTAs, despite growth projections that assume that $51 \%$ of new housing development and $53 \%$ of employment growth in the region will occur within HQTAs (SCAG, 2012, p. 131). 
Of SCAG's 15 sub regions, two have prepared their own additional SCS: Gateway Cities Council of Governments (GCCOG), and the Orange County Council of Governments (OCCOG). The Westside Cities Council of Governments, which includes the City of Los Angeles, has not prepared an additional SCS (SCAG, 2014). However, Metro and the City of Los Angeles have a number of transit-oriented development supportive policies, programs, and strategies in place that implement the RTP/SCS.

\subsubsection{Local transit-oriented land use planning}

Metro and the City of Los Angeles encourage transit-oriented development in different ways. Although areas around transit stations are mostly out of Metro's jurisdiction, they encourage local governments to enact land use policies that incentive transit-oriented development through policy guidance, technical support, and grant funding (Los Angeles County Metropolitan Transportation Authority, 2015; Center for Transit-Oriented Development, 2010, p. 74). Metro administers a TOD Planning Grant Program designed to facilitate the adoption of local land use regulations that support transit-oriented development (Los Angeles County Metropolitan Transportation Authority, 2015). Metro also operates the Metro Joint Development Program, a real estate management program that collaborates with developers to construct transitoriented developments on properties owned by Metro (Los Angeles County Metropolitan Transportation Authority, 2015a).

Transit-oriented development is encouraged in the Framework Element of the Los Angeles General Plan, and in Community Plans; physical development plans for specific areas. The Framework Element sets forth a long-term growth strategy that guides the update of community plans and other General Plan elements (Los Angeles Department of 
City Planning, 2001c). The Framework Element differs from other elements, as it is only intended to provide guidance for plan updates, including guidance on where growth should occur (Los Angeles Department of City Planning, 2001c).

The Framework Element has defined overlay zones that encourages different development types, densities, and intensities. Each category contains multiple zoning districts that correspond to their intended level of land use density/intensity. In order of density/intensity, the following five areas are: 1) Downtown Center (all of Downtown Los Angeles), 2) Regional Centers, 3) Community Centers, 4) Mixed-Use Boulevards, and 5) Neighborhood Districts (Los Angeles Department of City Planning, 2001a). Dense transit-oriented development is primarily encouraged in the Downtown Center, Regional Center, and Community Center categories. Most of these areas are located close to transit stations and lines. Specific land use and development characteristics of each land use category are summarized in table 2 .

The Framework Element identifies areas appropriate for transit-oriented development from a high-level perspective. Community Plans are the primary tool used by the city to change land use regulations to support transit-oriented growth (Center for TransitOriented Development, 2010, p. 84). The majority of Community Plans have land use policies and programs that support transit-oriented development, while the Southeast and South LA Community Plans have policies and programs in place that are specifically intended to support the RTP/SCS. Community Plans generally propose zone changes to encourage mixed-use development of greater density and intensity in areas close to transit (Los Angeles Department of City Planning, 2001b; 2012a; 2012b; 2012c; 2013; 2014a; $2014 ; 2014 c)$. 
Table 2: Summary of Land Use Categories

\begin{tabular}{|c|c|c|c|c|}
\hline $\begin{array}{l}\text { Land Use } \\
\text { Category }\end{array}$ & Types of Uses & Area Characteristics & $\begin{array}{l}\text { Floor-Area- } \\
\text { Ratio }\end{array}$ & $\begin{array}{l}\text { Zoning } \\
\text { Districts }\end{array}$ \\
\hline $\begin{array}{c}\text { Downtown } \\
\text { Center }\end{array}$ & $\begin{array}{l}\text { - Government Offices } \\
\text { - Industrial uses } \\
\text { - Major cultural and entertainment } \\
\text { facilities } \\
\text { - Hotels } \\
\text { - Professional offices } \\
\text { - Corporate headquarters } \\
\text { - Financial institutions } \\
\text { - High-rise residential towers } \\
\text { - Convention centers } \\
\end{array}$ & $\begin{array}{l}\text { - Highest density area of Los } \\
\text { Angeles } \\
\text { - Hub of regional public } \\
\text { transportation }\end{array}$ & $\begin{array}{l}\text { Generally up } \\
\text { to } 13: 1\end{array}$ & $\begin{array}{l}-\mathrm{CR} \\
-\mathrm{C} 1.5 \\
-\mathrm{C} 4 \\
-\mathrm{QC} 2\end{array}$ \\
\hline $\begin{array}{l}\text { Regional } \\
\text { Centers }\end{array}$ & $\begin{array}{l}\text { - Mixed use development } \\
\text { - Professional offices } \\
\text { - Concentrations of entertainment } \\
\text { and cultural facilities } \\
\text { - Regional-serving retail facilities } \\
\text { - Multi-family housing }\end{array}$ & $\begin{array}{l}\text { - Typically higher-density } \\
\text { areas } \\
\text { - Includes regional transit } \\
\text { hubs }\end{array}$ & $1.5: 1$ to $6: 1$ & $\begin{array}{l}-\mathrm{CR} \\
-\mathrm{C} 1.5 \\
-\mathrm{C} 4 \\
-[\mathrm{Q}] \mathrm{C} 2\end{array}$ \\
\hline $\begin{array}{l}\text { Community } \\
\text { Centers }\end{array}$ & $\begin{array}{l}\text { - Community-oriented uses } \\
\text { characterized by high activity } \\
\text { - Small offices } \\
\text { - Larger entertainment and cultural } \\
\text { facilities } \\
\text { - Public facilities } \\
\text { - Mixed-use development }\end{array}$ & $\begin{array}{l}\text { - Typically consist of mid- } \\
\text { rise buildings } \\
\text { - Includes bus and rail } \\
\text { stations }\end{array}$ & $1.5: 1$ to $3.0: 1$. & $\begin{array}{l}-\mathrm{CR} \text {, } \\
-\mathrm{C} 4 \\
-[\mathrm{Q}] \mathrm{C} 2\end{array}$ \\
\hline $\begin{array}{l}\text { Mixed-Use } \\
\text { Boulevards }\end{array}$ & $\begin{array}{l}\text { - Mixed-use development } \\
\text { - Retail commercial } \\
\text { - Offices } \\
\text { - Entertainment facilities } \\
\text { - Public facilities } \\
\text { - Neighborhood-serving uses }\end{array}$ & $\begin{array}{l}\text { - Connectors of } \\
\text { Neighborhood Districts, } \\
\text { Regional and Community } \\
\text { Centers. } \\
\text { - Served by a variety of } \\
\text { transportation facilities } \\
\end{array}$ & $1.5: 1$ to $4: 1$ & $\begin{array}{l}\text { Varied } \\
\text { depending } \\
\text { on location }\end{array}$ \\
\hline $\begin{array}{l}\text { Neighborhood } \\
\text { Districts }\end{array}$ & $\begin{array}{l}\text { - Neighborhood-serving uses } \\
\text { - Retail commercial } \\
\text { - Small cultural facilities } \\
\text { - Community facilities } \\
\text { - Mixed-use development }\end{array}$ & $\begin{array}{l}\text { - Typically consist of low- } \\
\text { rise buildings, oriented for } \\
\text { surrounding residential } \\
\text { neighborhoods }\end{array}$ & $1.5: 1$ or less & $\begin{array}{l}-\mathrm{C} 1 \\
-\mathrm{C} 1.5 \\
-\mathrm{C} 4 \\
-[\mathrm{Q}] \mathrm{C} 2\end{array}$ \\
\hline
\end{tabular}

Note. Land use and development characteristics were compiled from the Land Use Chapter and Executive Summary of the Framework Element of the Los Angeles General Plan (Los Angeles Department of City Planning, 2001c; Los Angeles Department of City Planning, 2001a; Los Angeles Department of City Planning, n.d.c).

In addition, the city is currently in the process of finalizing the Community Plan Implementation Overlay (CPIO), a land use tool that will bolster the implementation of development consistent with Community Plans, specifically the draft South and 
Southeast Community Plans. The CPIO will incentivize transit-oriented development through flexible zoning requirements and a streamlined review process (Center for Transit-Oriented Development, 2010, p. 85; Sulaiman, 2015).

\subsection{Complete Streets and Active Transportation}

\subsubsection{Introduction}

Encouraging dense, mixed-use development in areas close to transit is a critical step in building sustainable communities. Convenient access to transit, jobs, and amenities translates into less reliance on the automobile. However, land use factors are not the only variables that affect travel behavior. The transportation network must also be designed in a way that encourages active modes of transportation, namely walking and cycling, over the automobile. Although the ARO may have achieved its goal of encouraging greater residential densities and mixed-use development in areas adjacent to transit stations, it does not guarantee a reduction in vehicle miles travelled. The streets and sidewalks of these areas may prioritize the automobile over active transportation modes, resulting in urban areas that are not safe or convenient for modes of travel other than the automobile.

Regional and local transit-oriented development efforts in the Los Angeles area will help to create less auto-dependent communities. In order to successfully reduce automobile trips, transit-oriented development must be paired with a public realm conducive to alternative modes of transportation. According to Hank Dittmar, president of the Great American State Foundation, many transit-oriented neighborhoods are designed for automobile dependency, making them transit-adjacent rather than transitoriented (Tumlin \& Millard-Ball, 2003). Complete Streets are one strategy that can help to reduce automobile use in areas adjacent to transit. Complete Streets feature design 
characteristics that encourage active transportation modes of travel, such as bicycle lanes, curb bulb-outs, traffic calming measures, and safe pedestrian crossings (Los Angeles County Metropolitan Transportation Authority, 2014, p. 3). Research shows that transit commute shares increase with the implementation of pedestrian-oriented design treatments in areas adjacent to transit stations (Cervero, 2004, p.157), and that an increase in lineal miles of bicycle facilities contribute to a growth in accessing rail stations by bicycle (Cervero, Caldwell, \& Cuellar, 2012).

In Los Angeles, regional and local planning entities have realized the importance of Complete Streets in curbing automobile use. They have begun to develop and implement strategies aimed to better coordinate transit investments and transit-oriented developments with active transportation investments. If active transportation investments are implemented in ARO incentive areas, it may create a synergistic effect in reducing vehicle miles travelled.

\subsection{2 $A B 1358$ and $S B 375$}

Enacted in 2008, the Complete Streets Act (AB 1358, 2008) requires cities and counties to incorporate Complete Streets principles into their circulation element when performing General Plan updates (AB 1358, 2008; SCAG, 2012, p. 55). These principles are intended to foster a multimodal transportation network that accommodates all users of streets - pedestrians, cyclists, and motorists. When paired with SB 375, these two bills have the potential to advance transit-oriented growth in a way that is largely unprecedented. Both are considered as landmark planning legislation in California. Although there is no explicit language in SB 375 or AB 1358 stating that the two bills should be linked during implementation, they both share similar end goals to reduce 
vehicle miles travelled (SB 375, 2008; AB 1358, 2008). SB 375 approaches this goal by encouraging transit-oriented development, while AB 1358 approaches this goal by encouraging active transportation. In this regard, the two are fundamentally linked. Land use changes and transportation investments will go a long way in reducing greenhouse gas emissions. However, $\mathrm{AB} 1358$ provides the impetus for the mode shift required to reduce vehicle use. An optimal planning strategy to reduce vehicle miles travelled requires both approaches.

\subsubsection{SCAG RTP/SCS overview: active transportation}

Complete Streets and active transportation is a key cornerstone of the Southern California Association of Government's Regional Transportation Plan and Sustainable Communities Strategy (RTP/SCS). The RTP/SCS includes goals to increase funding and accommodations to promote greater bicycle and pedestrian mobility (SCAG, 2012a). Similar to the land use component of the RTP/SCS, SCAG will primarily play an advisory role to local governments in an effort to support Complete Streets and active transportation facilities in the region. However, SCAG will allocate funding to local governments to plan and implement Complete Streets and active transportation facilities in their jurisdictions. The RTP/SCS has allocated $\$ 6.7$ billion to engineering, enforcement, and education strategies related to active transportation and Complete Streets (SCAG, 2012, pp. 40, 55). The $\$ 6.7$ billion of funding does not include locally funded projects or large development projects that involve the construction of bicycle and pedestrian facilities. When factoring in local expenditures, the region is expected to spend more than $\$ 10$ billion on active transportation investments by 2035 (SCAG, 2012a, p. 4). 


\subsubsection{Local active transportation planning}

Localities and entities within the SCAG region have proposed and implemented a number of active transportation and Complete Streets projects. The development of a comprehensive, regional network of bicycle facilities is proposed in the draft Los Angeles County Bicycle Master Plan and the Metro Long Range Transportation Plan (SCAG, 2012a, p. 3). Metro has supplemented this effort with their draft Compete Streets Policy, which provides guidance and funding to local agencies to develop Complete Streets projects in their jurisdictions (Los Angeles County Metropolitan Transportation Authority, 2014, p. 3). Metro's Complete Streets Policy has ranked higher than any region in California by Smart Growth America (Curry, 2015). Metro is particularly interested in the implementation of Complete Streets on "first/last" streets used to get to and from transit stations. In 2013 Metro released their draft First Last Mile Strategic Plan, a set of planning guidelines (consisting of policy guidance and design treatment examples) with the goal of improving active transportation accessibility to Metro stations (Los Angeles County Metropolitan Transportation Authority, 2014a, p. 3).

The draft 2014 update of the Circulation Element of the City of Los Angeles General Plan, referred to as "Mobility 2035", strongly emphasizes the incorporation of Complete Streets principles in the transportation system. Three of the nine key policy initiatives explicitly address Complete Streets and active transportation. These policy initiatives include the establishment of new Complete Streets standards, the promotion of "first mile-last-mile" connections, and the expansion of the role of the street as public space (Los Angeles Department of City Planning, 2014e, p. 6). The element also proposes the establishment of areas prioritized for pedestrian improvements, the development of an 
interconnected bicycle network, and the enhancement of multi-modal transportation services in areas close to transit stations (Los Angeles Department of City Planning, 2014e, pp. 61, 64, 80). Mobility Plan 2035 has yet to be adopted. As Linton (2015) points out, the plan serves as a departure from the auto-centric character of Los Angeles to "an emerging multi-modal Los Angeles that embraces walking, bicycling, using transit, and driving".

In 2011, the Downtown Los Angeles Neighborhood Council (DLANC) formed the Complete Streets Working Group to implement design treatments aimed to improve downtown's cycling and pedestrian environment (Downtown Los Angeles Neighborhood Council, n.d.). The DLANC Working Group is a partnership between various non-profit organizations, local politicians, and the Los Angeles Department of Transportation (LADOT). According to their website, the DLANC Working Group has primarily focused on the development of bicycle facilities and parklets. The website does not mention traffic calming strategies, education strategies, and enforcement strategies. The DLANC Working Group has been responsible for the implementation of Downtown Los Angeles's first bicycle lane along a segment of Spring Street, as well as bicycle lanes on two more road segments (Downtown Los Angeles Neighborhood Council, n.d.). A 40\% increase in bicycle ridership along Spring Street was observed one year after installation of the bicycle lane (Downtown Los Angeles Neighborhood Council, n.d.). DLANC is also providing assistance on the efforts of the LADOT to develop a more comprehensive bicycle network in Downtown Los Angeles. DLANC's efforts will compliment new housing and commercial space created by the ARO with active transportation facilities, further helping to reduce vehicle miles travelled. 


\section{METHODOLOGY}

\subsection{Introduction}

Two series of analysis were used to answer the following research questions:

1. Has the ARO contributed to transit-oriented growth?

2. Has the ARO had an impact on development activity in the Central City area?

The first analysis aims to examine the spatial distribution of ARO projects, specifically focusing on the number of ARO projects located within a half-mile radius of Metro stations, as well as the relationship of ARO projects to new development constructed between 1999 and 2013. The second analysis aims to examine how the ARO has impacted development activity within the Central City area. The following chapter describes the purpose, design, justification, and process used for each method of analysis. Findings from each method of analysis are discussed in the following chapter. Before discussing methods of analysis, it is important to first note data limitations. Although data used in this thesis adequately addressed research questions, there were some limitations in data that restricted the ability for comprehensive analysis.

\subsection{Data limitations}

\subsubsection{ARO projects}

A list of ARO projects completed between 1999 and 2014 has been provided by a planner with the Los Angeles Department of City Planning. This data is not published or available to the public (Los Angeles Department of City Planning, 2014f). This list included a variety of information on each ARO project, including: project address; number of stories; number of dwelling units; building permit number; project status 
(permit issued, feasibility study, certificate of occupancy issued), and; a brief description of the project. Additional building/project characteristics have been obtained from ZIMAS, a GIS-based interactive mapping program run by the City of Los Angeles Planning Department. The ZIMAS database includes a variety of building, permit, and assessor data specific to each parcel in the City of Los Angeles. Using ZIMAS, additional information has been found for each ARO project, including: project approval and completion date; conversion use; number of dwelling units created through conversion; number of commercial units and storefronts created through conversion; number of on and off-site parking spaces allocated to each building; building square footage; year building was constructed, and; California Historic Resource Status Code (level of historic resource designation). This information was obtained from Zoning Administrator determinations, vesting tentative tract maps, and building permits, all of which are appended to ZIMAS.

The number of dwelling units, commercial condominiums, and square footage of commercial space created through conversion projects was approximated through analysis of vesting tentative tract maps, zoning administrator determinations, and building permits. These forms sometimes had conflicting numbers of units, commercial spaces, and on-site parking spaces. Although these forms had conflicting numbers in some cases, they generally did not vary significantly. For some projects, specific characteristics (dwelling units, parking spaces) were unable to be found through ZIMAs.

\subsubsection{Development data limitations}

In order to examine development trends for the Central City area, data on the number of new buildings constructed per year was required. The most significant data limitation 
was for development permits. Available development permit data only spans from January 2013 to January 2015, obtained from the city open-data portal. Earlier permit data is available from 2001 to 2014 through Plan Check and Inspection Disks, obtained from the Department of Building and Safety (DBS). These disks only include monthly permit data, they cost $\$ 11$ each, and they must be purchased in person from the DBS office in Los Angeles. Earlier permit data (prior to 2001) must be viewed on microfilm at the DBS office. Because this data could not be obtained, examination of development trends relied on building age data reported in 2014 Los Angeles County Assessors data.

The 2014 Los Angeles County "Local Roll" was obtained online from the County of Los Angeles GIS data portal. The Local Roll consists of Los Angeles County Assessor data for 2014, which includes building age along with other useful parcel-level data (Los Angeles County Office of Assessor, 2014). This data was joined with a building outline shapefile (Los Angeles County GIS Data Portal, 2014) in GIS, which provided the year built for approximately every building in the City of Los Angeles. To examine annual development trends from 1985 to 2013, building age data was used. The numbers of buildings were recorded from 1985 to 2013 in the Central City area. 2014 Assessor data only includes the age of buildings until 2013. Building age data from 2013 to 2015 would have to be obtained from 2015 Assessor data, which is not yet available to the public. Figure 3 located on the following page better displays the process involved in obtaining building age data. 
Figure 3: Process of Obtaining Building Age Data

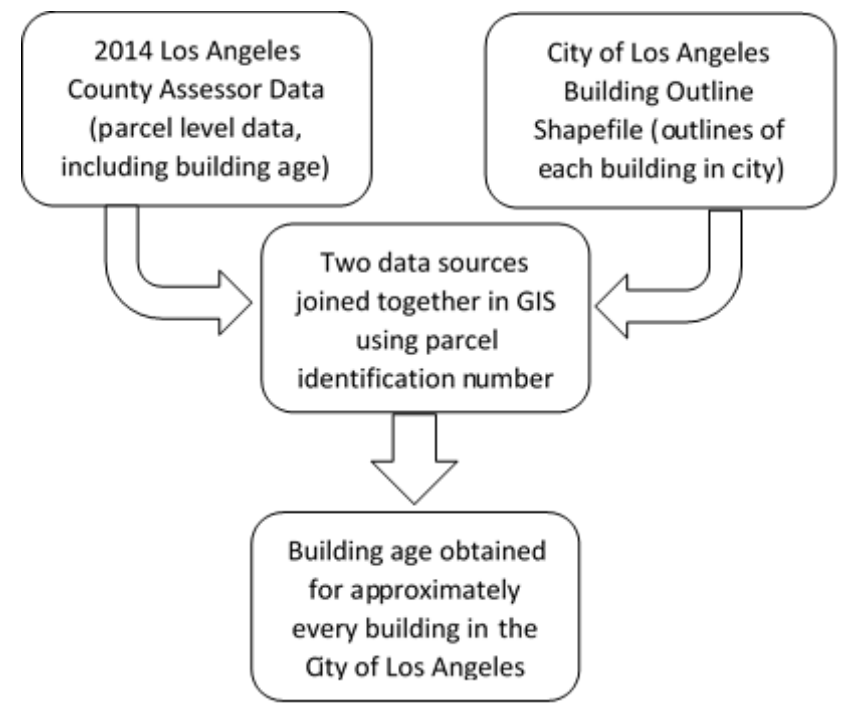

\subsection{Metro Station Spatial Analysis}

\subsubsection{Overview of methodology}

A spatial analysis was the first method used in this study to address research questions. The spatial analysis was intended to explore the geographic characteristics of ARO projects. The analysis began by analyzing the distribution of ARO projects, whether they are evenly distributed throughout the city or concentrated in certain areas. The number of ARO projects located within a half-mile radius of Metro rail stations was then determined. A half-mile radius was used because it is the common standard for the planning of transit-oriented developments in the United States (Guerra, Cervero, \& Tischler, 2012), and because the area overlaps with districts where transit-oriented growth is encouraged by SCAG and the City of Los Angeles. A ratio of ARO projects to new buildings constructed between 1999 and 2013 was calculated within and outside of the half-mile radius. This step in the analysis is indented to examine the geographic relationship of ARO projects to new development, and to determine where the ARO has 
affected new development activity. For example, if ratios of new developments to ARO projects are lower in transit-adjacent areas, one could infer it has impacted transitoriented growth. GIS was used for each analysis.

\subsubsection{The half mile buffer}

A half-mile buffer around Metro stations was used as a unit of analysis for several reasons. A half-mile radius is the standard transit station catchment area used in the United States, and it has come to represent the spatial extent of most transit-oriented development planning (Guerra, Cervero, \& Tischler, 2012). Transit station catchment areas are based on the average distance people are willing to walk to take transit (Guerra, Cervero, \& Tischler, 2012, p. 2). Catchment areas are used as a geographic unit of analysis to assess the impacts of transit investments, predict ridership levels, and to guide land-use policy. Research has found that outside of a half-mile radius of transit stations, ridership levels drop dramatically (Koko, 2011, p. 16; Bedsworth, Hanak, \& Kolko, 2011, p. 10). The presence of a transit station strongly influences land use characteristics of adjacent areas. Areas within a half-mile radius of transit stations typically have higher land values, residential densities, and commercial densities than other areas (Koko, 2011, p. 22). Erick Guerra, Robert Cervero, and Daniel Tischler (2011) found that a half-mile radius is the most appropriate catchment to use when prescribing land-use policy for residential land uses in particular.

The Southern California Association of Governments encourages the City of Los Angeles to target growth in areas within High-Quality Transit Areas (HQTA) and Transit Priority Areas (TPA) (SCAG, 2012, p. 131). In the City of Los Angeles, all areas within a half-mile radius of Metro rail stations have been designated as both an HQTA and a TPA. 
As displayed in figure 4, the majority of the City of Los Angeles is designated as an HQTA. SCAG has already defined TPAs as areas within a half-mile of an existing or planned transit station (SCAG, n.d). Much of the Central City area is designated as a TPA. 145 ARO projects (95\% of total projects) have been developed within the boundaries of SCAG TPAs and HQTAs.

The City of Los Angeles also encourages growth to occur in areas within a half-mile radius of Metro stations. As displayed in figure 5, the majority of higher-intensity landuse districts established in the Framework Element of the General Plan (Downtown Center, Regional Center, and Community Center) are located in these areas. These overlay zoning categories have been identified by the City of Los Angeles as appropriate locations for transit-oriented growth (Los Angeles Department of City Planning, 2001c). Although the half-mile buffer generally overlaps with the location of these districts, some Regional and Community Centers are located outside of these buffers. ARO projects are only located in Regional and Community Centers in the Central City, Central City North, Westlake, Wilshire, and Hollywood Community Plan Areas. 47\% of ARO projects (72 in total) have been developed within the boundaries of Regional Centers, and $8 \%$ of ARO projects (12 in total) are located within the boundaries of Community Centers (see figure $6)$.

A half-mile transit buffer is appropriate for analysis from a regional and local planning perspective. Regional and local planning entities both agree that growth, especially transit-oriented growth, should be prioritized in these locations. Because of these geographic similarities, it would be redundant to perform the same analysis on SCAG HQTAs and TPAS, and on locally designated transit-oriented land use districts. 
By examining one geographical area, this analysis aims to take into account the spatial distribution of ARO projects as it relates to the context of regional and local transitoriented development planning.

Figure 4: Map of SCAG High Quality Transit Areas and Transit Priority Areas

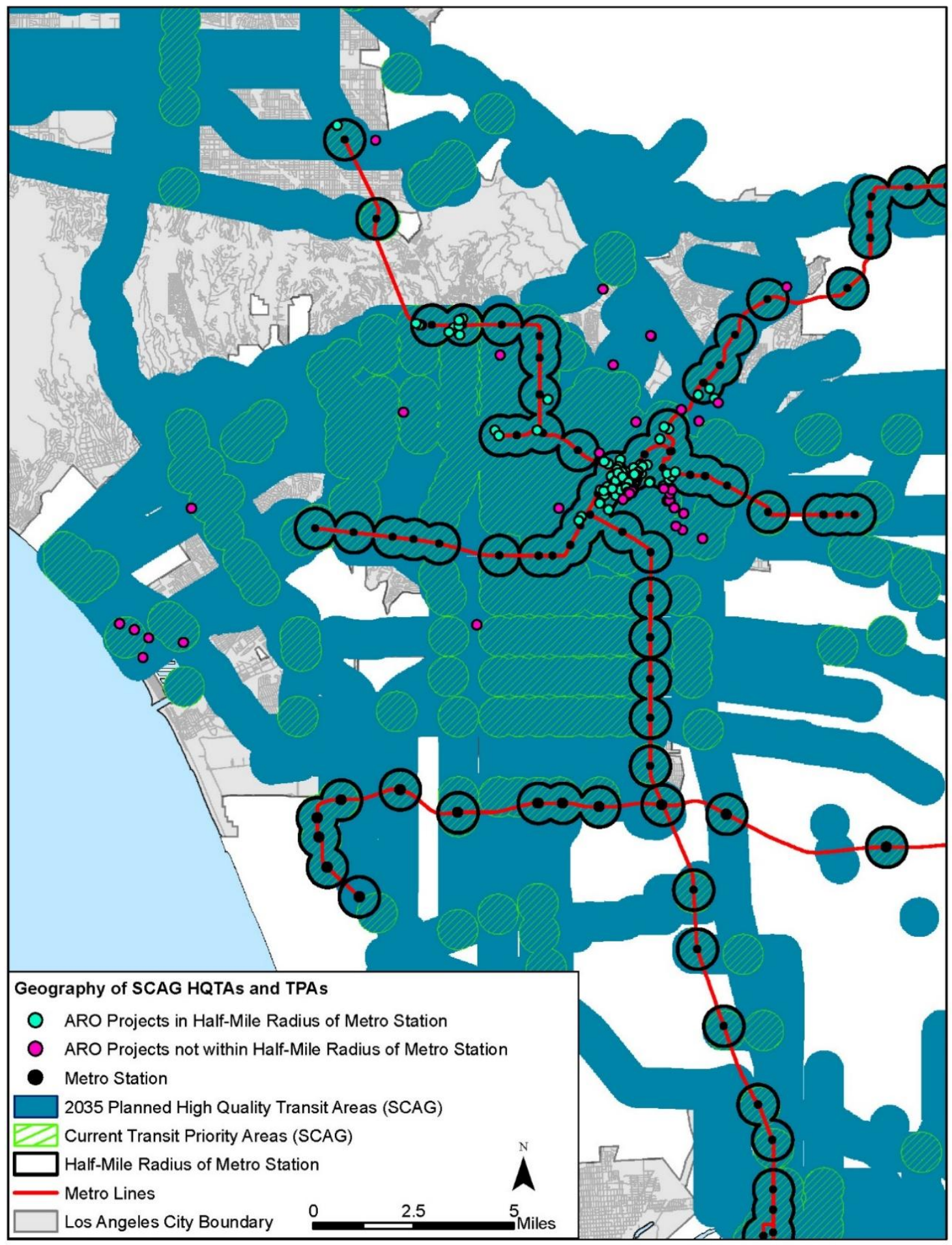


Figure 5: Map of Select Regional and Community Land Use Districts

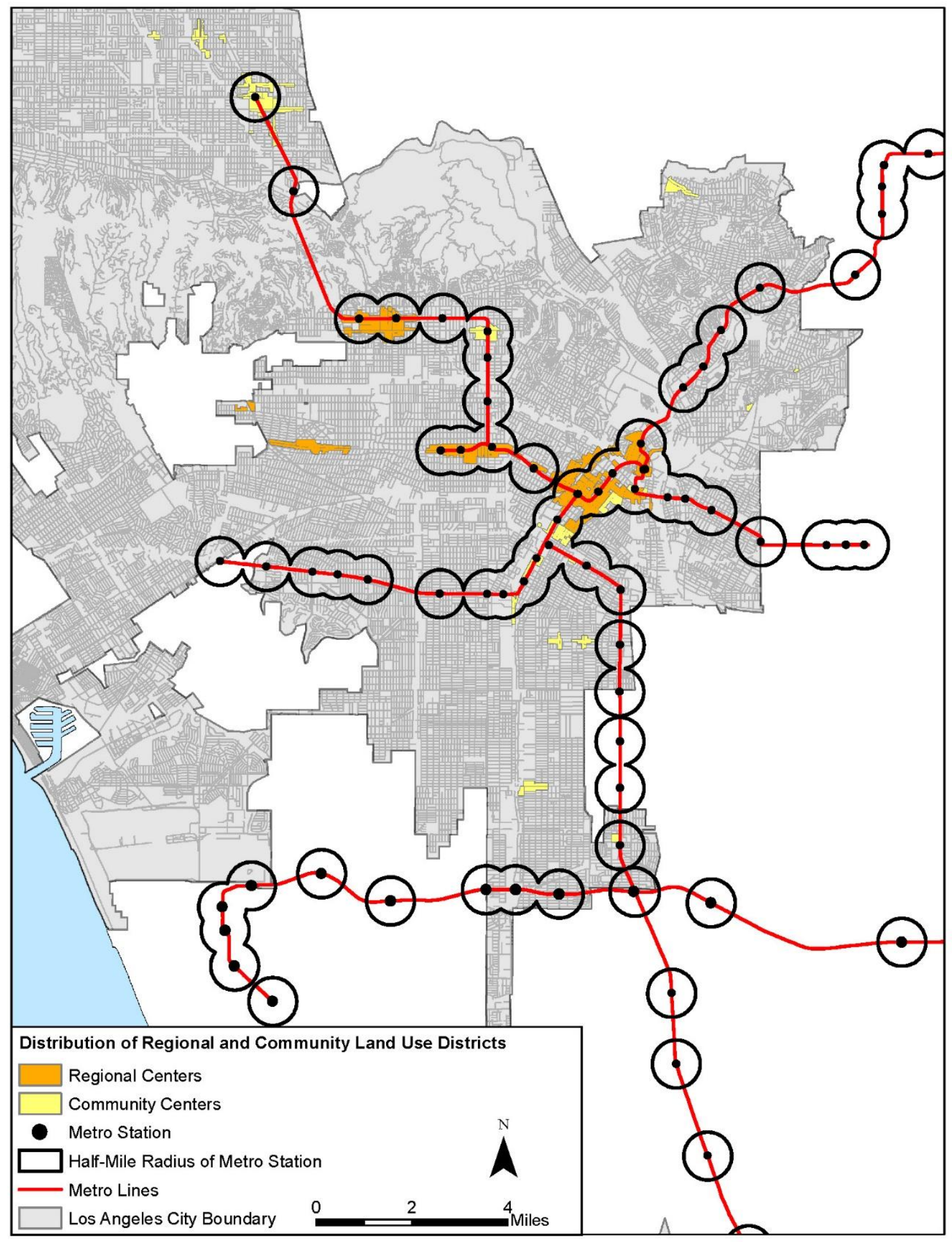


Figure 6: ARO Projects Inside Higher-Intensity Land Use Districts

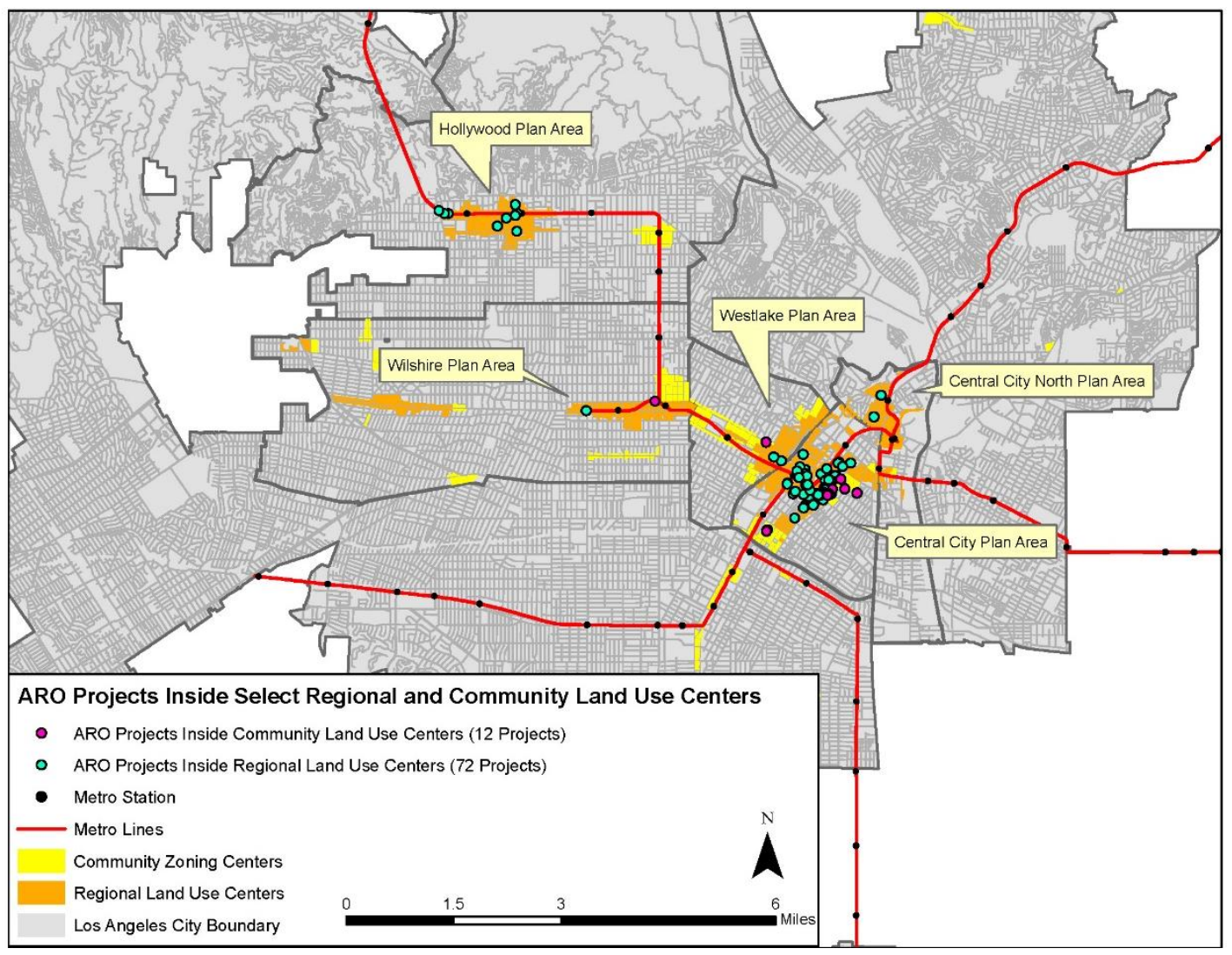

Table 3: ARO Project Characteristics Inside Higher-Intensity Land Use Districts

\begin{tabular}{|c|c|c|c|c|c|}
\hline \multirow{2}{*}{ Project Characteristics } & Total & \multicolumn{2}{|c|}{$\begin{array}{c}\text { ARO Projects Inside } \\
\text { Selected Regional Land } \\
\text { Use Centers }\end{array}$} & \multicolumn{2}{|c|}{$\begin{array}{c}\text { ARO Projects Inside } \\
\text { Selected Community } \\
\text { Land Use Centers }\end{array}$} \\
\cline { 3 - 6 } & & Number & $\begin{array}{c}\% \text { of Total } \\
\text { Projects }\end{array}$ & Number & $\begin{array}{c}\% \text { of Total } \\
\text { Projects }\end{array}$ \\
\hline Citywide & 153 & 72 & $47 \%$ & 12 & $8 \%$ \\
\hline $\begin{array}{c}\text { Number of Dwelling } \\
\text { Units }\end{array}$ & 13,296 & 7,635 & $57 \%$ & 1,233 & $9 \%$ \\
\hline $\begin{array}{c}\text { Commercial } \\
\text { Condominiums or } \\
\text { Units }\end{array}$ & 689 & 644 & $93 \%$ & 12 & $2 \%$ \\
\hline $\begin{array}{c}\text { Conversion Date } \\
\text { Range }\end{array}$ & $1999-$ & $1999-2014$ & & $2000-2007$ & \\
\hline
\end{tabular}

1. The number of dwelling units, commercial condominiums and square footage of commercial space are approximations made through numbers provided by vesting tentative tract maps, zoning administrator determinations, and building permits. These different forms often had conflicting numbers of units, commercial spaces, and parking spaces.

2. Conversion date ranges from the date of the zoning administrator's approval to the date when the permit was issued. 


\subsection{Development Trend Analysis - Central City Area}

\subsubsection{Overview of methodology}

A statistical analysis was used to examine how the ARO has affected development trends within the Central City area. Because of access to regional transit, all development in the Central City area is inherently transit-oriented. The purpose of this analysis was to determine if development increased, decreased, or remained at a constant rate before and after the adoption of the ARO. Using GIS, data for buildings constructed between 1983 and 2013 within the Central City area was exported into a Microsoft excel table. This data was obtained through joining 2014 parcel-level assessor data with a building footprint shapefile in GIS. An X-Y scatter chart was created in Microsoft excel to illustrate Central City development trends over a 28-year time period, 14 years prior to and after the adoption of the ARO (1985 to 2013). Polynomial trend lines (used because of fluctuations in data) provide an indication of the overall course of development that has occurred during this time period.

\subsubsection{Justification for Central City focus}

The Central City area is a sub-area of Downtown Los Angeles bounded by Highways 101, 110, 10, and Alameda Street. The downtown neighborhoods of Chinatown and the Arts District (located inside the Central City North Community Plan Area) are not included in the Central City area (see figure 7). The majority of ARO projects (56\%) are located in the Central City area. In the Central City area as a whole, there have been eighty-six ARO projects, eighty-one of which are located within a half-mile radius of Metro stations. Outside of the Central City area, ARO projects are somewhat randomly 
distributed throughout the city. Small clusters of ARO projects are located in half-mile metro buffers outside of the Central City area (see figure 8 on page 63). It is somewhat unlikely that ARO projects have affected development activity in these areas.

Figure 7: Central City Community Plan Area

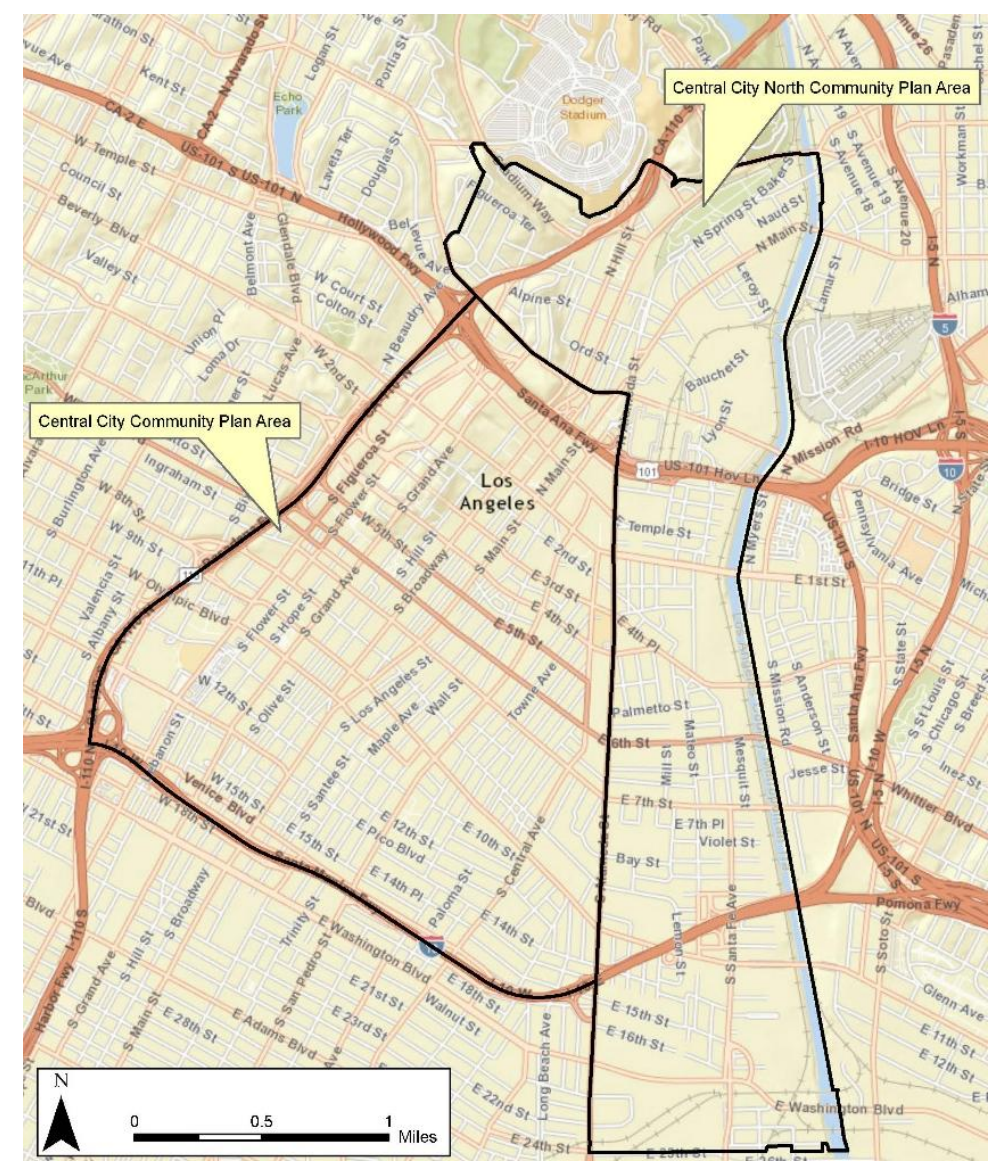

However, it is likely that ARO projects have affected development activity in the Central City area. The ratio of new buildings constructed between 1999 and 2013 to ARO projects is much smaller in the Central City area than other areas of the city. There have been 128 buildings constructed between 1999 and 2013 in the Central City area. The ratio of new buildings to ARO projects is 1.5 for the Central City area as a whole: $1: 1$ for areas within a half-mile radius of Metro stations, and 9:1 for areas outside of this radius. The citywide ratio of new buildings constructed between 1999 and 2013 to ARO projects is 
14:1. This $1: 1$ ratio justifies a development trend analysis specific to the Central City area.

A development trend analysis specific to the Central City area was also performed to support, or dispute, statements made about the ARO in literature. The ARO has met the most success in Downtown Los Angeles. Researchers and planners have claimed that the ARO has had a transformative impact on Downtown Los Angeles, significantly contributing to the area's revitalization (Bell, 2014; Los Angeles Department of City Planning, 2014d, pp. 9-13; The Partnership for Building Reuse, 2013, pp. 9, 26, 39; Bullen \& Love, 2009, pp. 355-358; Mayor's Office of Economic Development, 2004, p. 22; Bernstein, 2012). These claims are justified by discussions of how the ARO increased the area's residential population and mix of land uses. There are no discussions of whether or not the ARO contributed to wider smart growth goals (transit-oriented growth in particular) by accelerating infill development activity in the area.

The Central City area is one of the most appropriate areas in the City of Los Angeles for transit-oriented growth. The majority of the Central City area is within a half-mile radius of Metro stations. Virtually the entire area falls within the boundaries of SCAG Transit Priority Areas and High Quality Transit Areas. Of all the subareas within the City of Los Angeles, the most dense and intensive development is encouraged in the Central City area. The Department of City Planning encourages new developments here to have floor-area-ratios up to $13: 1$, more than twice the floor-area-ratio encouraged in any other area of the city (Los Angeles Department of City Planning, 2001c). From a smart growth perspective, Downtown Los Angeles is arguably among the most sensible areas in the region for revitalization, infill development, and densification. 


\section{FINDINGS}

\subsection{Metro Station Spatial Analysis}

\subsubsection{Spatial Distribution of ARO Projects}

From 1999 to 2002, all ARO projects (fourteen in total) were developed within the Central City area. In 2003, the ARO was expanded to the Hollywood, Wilshire, Koreatown, Chinatown, Lincoln Heights, and Central Avenue areas (Mayor's Office of Economic Development, 2004, p. 7). From 2003 to 2005, ARO projects began to expand into these areas, although the majority of projects (54\%) continued to occur in the Central City area. Fifty-five ARO projects were completed between 2006 and 2008, with 56\% located in the Central City area. From 2009 to 2013, thirteen ARO projects were completed, with only five located in the Central City area. Insomuch as projects were developed outside of the downtown incentive area over time, the majority continued to occur inside the Central City area. Figure 8 displays ARO project development during four time periods.

In general, ARO projects are not evenly distributed throughout the city. The majority of ARO projects (73\%) are concentrated inside the five designated incentive areas. Eighty-eight are located within the Downtown Incentive Area, three are located in the Wilshire incentive area, eleven are located in the Hollywood Incentive Area, and ten are located in the Chinatown/Lincoln Heights incentive area. No projects are located in the Central Avenue incentive area. Forty-two ARO projects are located outside of incentive areas. These projects are generally dispersed throughout the Central City North area, while a small cluster is located in the Venice neighborhood. 
On a citywide basis, 110 ARO projects ( $72 \%$ of total projects) have been developed within a half-mile radius of Metro rail stations, and forty-three (28\% of total projects) have been developed outside of this radius (see table 4 and figure 9). ARO projects developed within a half-mile radius of Metro rail stations have created approximately 10,654 dwelling units, 670 commercial condominiums, and 92,853 square feet of commercial and/or retail space. ARO projects developed outside of the half-mile radius have created approximately 2,642 dwelling units, 19 commercial condominiums, and 72,000 square feet of commercial and/or retail space. Conversion dates range from 1999 to 2014. The majority of ARO projects (53\% of total projects) within a half-mile radius of Metro Stations are located within the Central City area.

Because ARO projects converted vacant space to residential or commercial space in areas adjacent to transit stations, it did contribute to transit-oriented growth to a certain degree. Without the ARO, these properties may have remained vacant, or even demolished from neglect. Because of perceptions of blight, vacant buildings could deter development interest in these areas, thereby hindering transit-oriented growth.

To better understand how the ARO has contributed to transit-oriented growth, one must take into account how the ARO has affected new infill development activity. If new development in transit-adjacent areas significantly outpaces ARO projects, it is likely that the ARO had little impact on transit-oriented growth. Conversely, if new developments are similar in ratio to $\mathrm{ARO}$ projects, than the ARO may have had a role in contributing to transit-oriented growth. The relationship between new development and ARO projects grows stronger as ratios decrease. 
Figure 8: ARO Project Development in Four Time Periods

ARO Projects: $1999-2002$

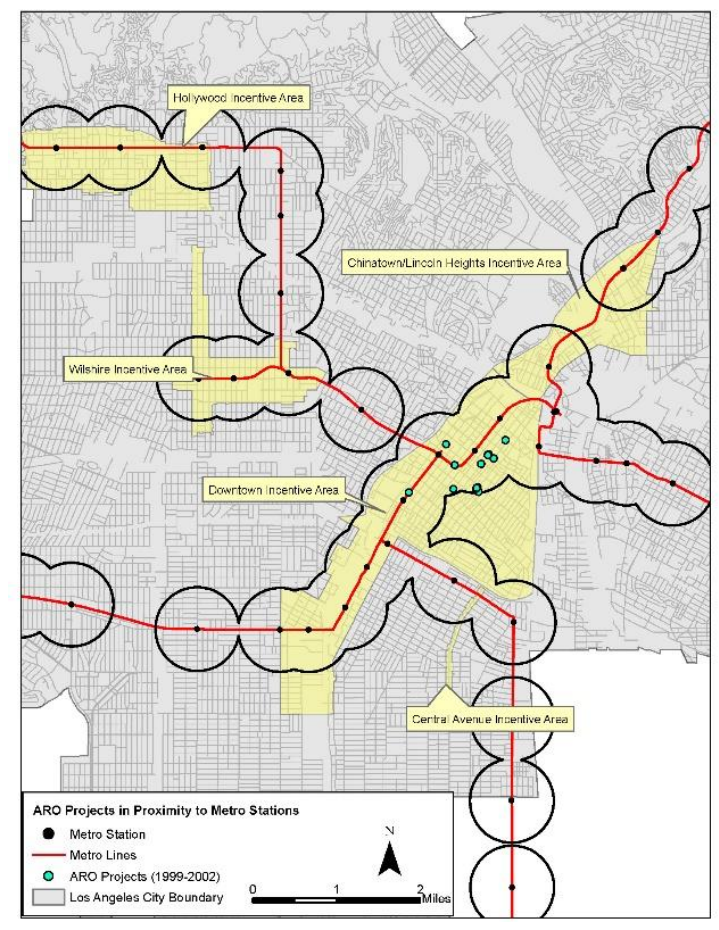

ARO Projects: 2006 - 2008

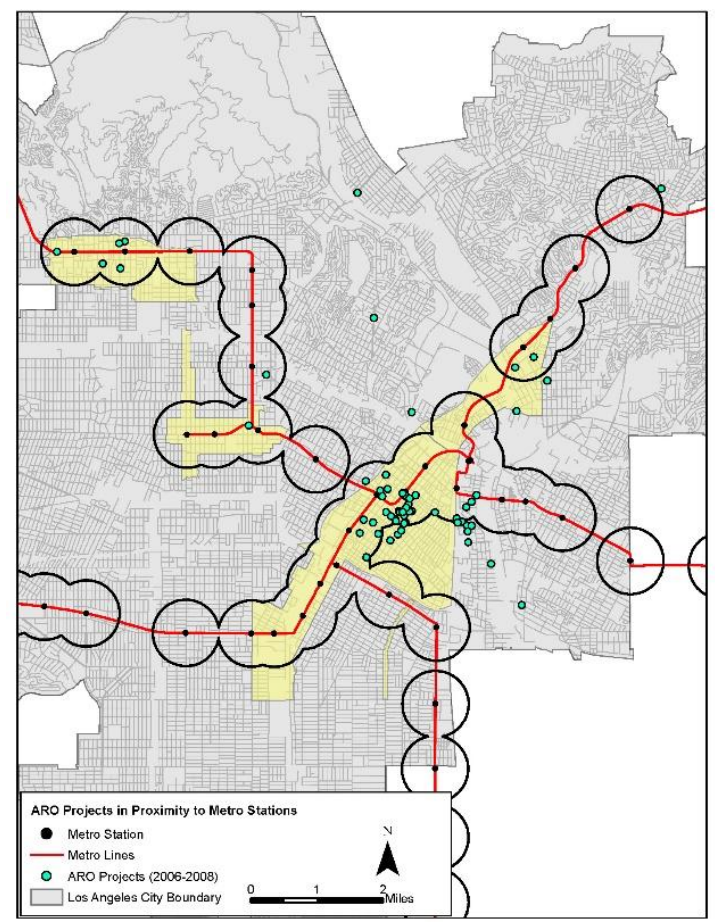

ARO Projects: $2003-2005$

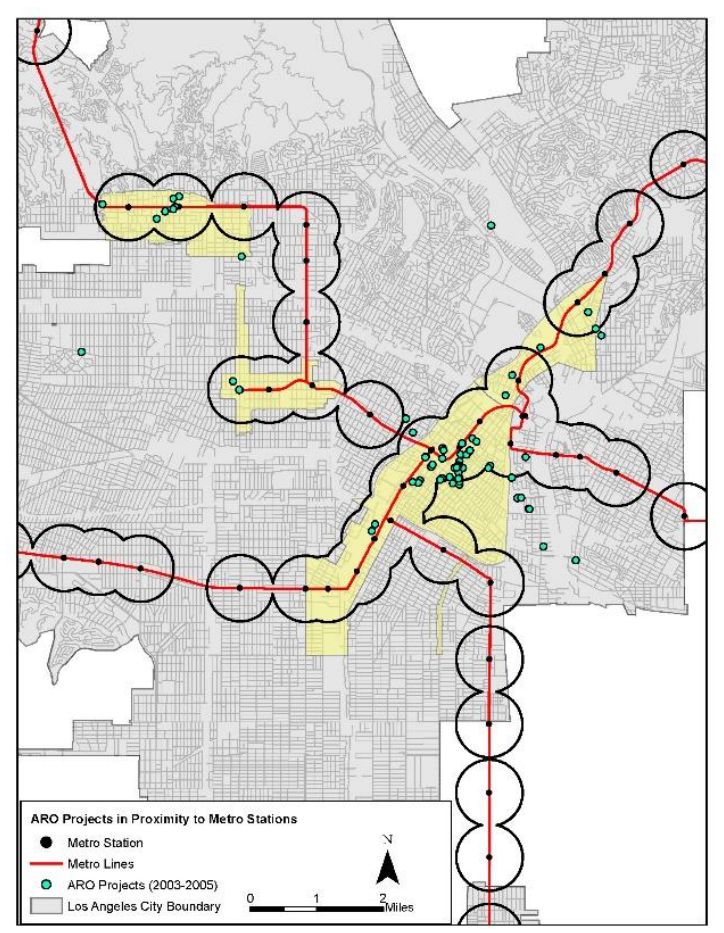

ARO Projects: 2009 - 2013

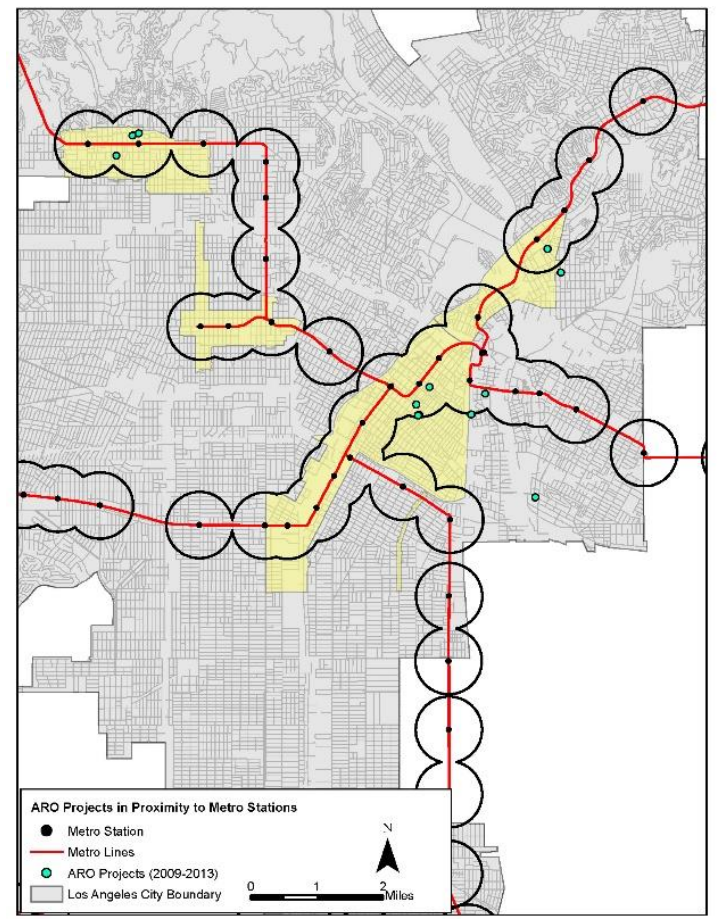


Figure 9: Spatial Distribution of ARO Projects

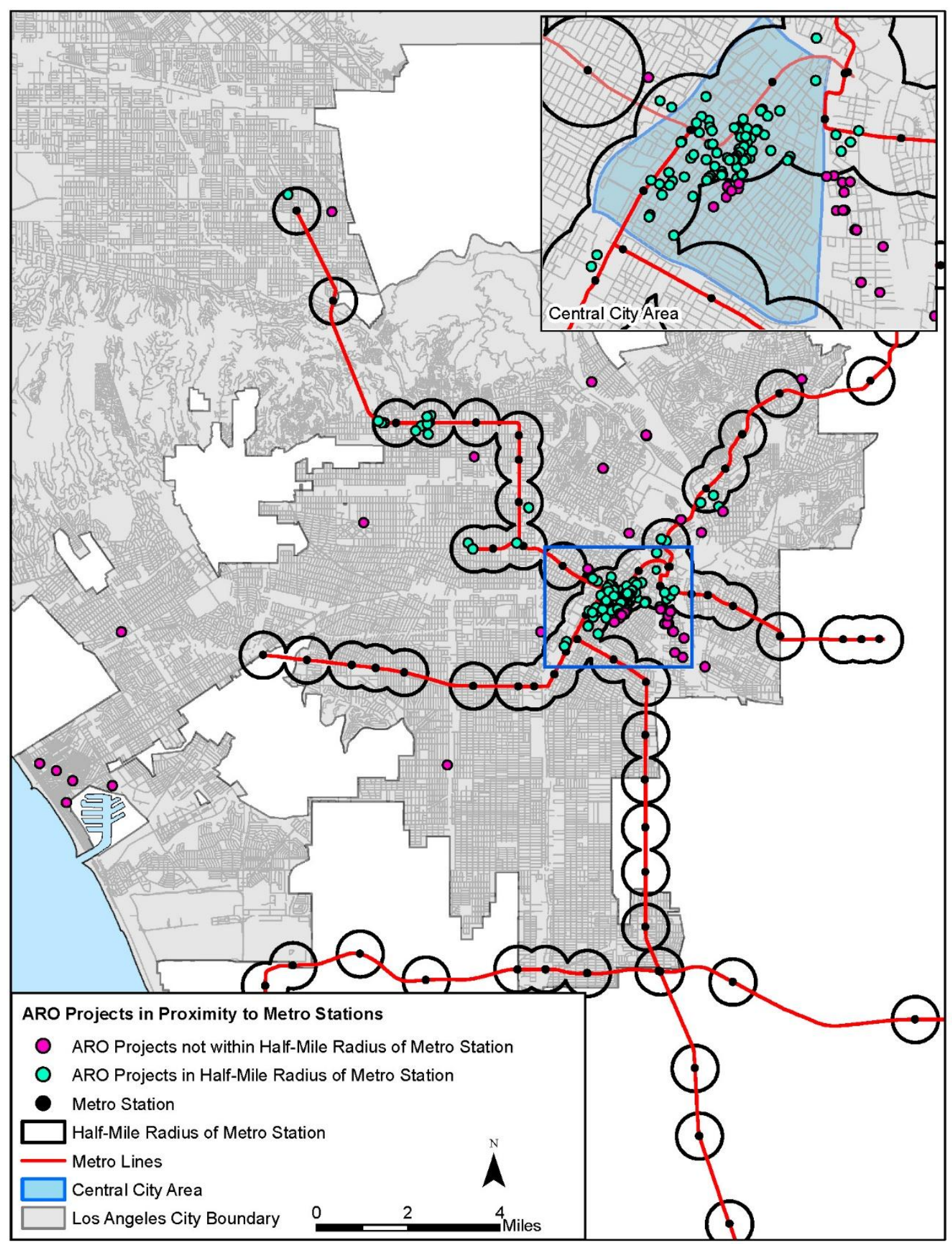


Table 4: Metro Buffer Analysis, ARO Projects

\begin{tabular}{|c|c|c|c|c|c|}
\hline \multirow{2}{*}{ Project Characteristics } & \multirow[b]{2}{*}{ Total } & \multicolumn{2}{|c|}{$\begin{array}{l}\text { ARO Projects in Half Mile } \\
\text { of Metro Station }\end{array}$} & \multicolumn{2}{|c|}{$\begin{array}{l}\text { ARO Projects not within } \\
\text { Half Mile of Metro Station }\end{array}$} \\
\hline & & Number & $\begin{array}{l}\% \text { of Total } \\
\text { Project }\end{array}$ & Number & $\begin{array}{l}\% \text { of Total } \\
\text { Projects }\end{array}$ \\
\hline Citywide & 153 & 110 & $72 \%$ & 43 & $28 \%$ \\
\hline $\begin{array}{l}\text { Number of Dwelling } \\
\text { Units }^{1}\end{array}$ & 13,358 & 10,716 & $80 \%$ & 2,642 & $20 \%$ \\
\hline $\begin{array}{c}\text { Commercial } \\
\text { Condominiums }\end{array}$ & 689 & 670 & $97 \%$ & 19 & $3 \%$ \\
\hline $\begin{array}{l}\text { Square Footage of } \\
\text { Commercial Space }\end{array}$ & 164,853 & 92,853 & $56 \%$ & 72,000 & $44 \%$ \\
\hline Conversion Date Range ${ }^{2}$ & $\begin{array}{l}1999- \\
2014\end{array}$ & $2000-2014$ & & $1999-2013$ & \\
\hline
\end{tabular}

1. The number of dwelling units, commercial condominiums and square footage of commercial space are approximations made through numbers provided by vesting tentative tract maps, zoning administrator determinations, and building permits. These different forms often had conflicting numbers of units, commercial spaces, and parking spaces.

2. Conversion date ranges from the date of the zoning administrator's approval to the date when the permit was issued.

Table 5: Metro Buffer Analysis, Buildings Constructed Between 1999 and 2013

\begin{tabular}{|c|c|c|c|c|c|}
\hline \multirow{2}{*}{$\begin{array}{l}\text { Development } \\
\text { Characteristics }\end{array}$} & \multirow{2}{*}{ Total } & \multicolumn{2}{|c|}{$\begin{array}{l}\text { Buildings Constructed in } \\
\text { Half Mile of Metro Station }\end{array}$} & \multicolumn{2}{|c|}{$\begin{array}{l}\text { Buildings Constructed not } \\
\text { within Half Mile of Metro } \\
\text { Station }\end{array}$} \\
\hline & & Number & $\%$ of Total & Number & $\%$ of Total \\
\hline Citywide & 26,144 & 1,486 & $6 \%$ & 24,658 & $94 \%$ \\
\hline $\begin{array}{l}\text { Single Family } \\
\text { Dwelling }\end{array}$ & 19,931 & 506 & $3 \%$ & 19,425 & $97 \%$ \\
\hline $\begin{array}{l}\text { Multi-Family } \\
\text { Dwelling }\end{array}$ & 3,972 & 620 & $16 \%$ & 3,352 & $84 \%$ \\
\hline Commercial & 1,329 & 218 & $16 \%$ & 1,111 & $84 \%$ \\
\hline Other ${ }^{1}$ & 912 & 142 & $16 \%$ & 770 & $84 \%$ \\
\hline
\end{tabular}

Note. Building age data has been obtained from the 2014 Los Angeles County Assessor data for 2014.

1. "Other" includes industrial, institutional, recreational, and miscellaneous buildings. 


\subsubsection{ARO projects compared to new development}

Table 6 displays ARO projects compared to buildings constructed between 1999 and 2013. The ratios in this table serve to quantify the concentration of ARO projects to development that occurred during the same time period (between 1999 and 2013). On a citywide scale, the number of ARO projects is small compared to the number of buildings constructed between 1999 and 2013. For one ARO project there were 171 buildings constructed between 1999 and 2013. In areas within a half-mile radius of Metro stations, the ratio of buildings constructed between 1999 and 2013 to ARO projects is 14:1. This ratio increases dramatically in areas outside of a half-mile radius of Metro stations. In these areas the ratio of buildings constructed between 1999 and 2013 to ARO projects is 573:1. Because the ratio of new development to ARO projects is the lowest within a halfmile radius of Metro stations, one can infer that the ARO has had a greater impact on development activity in transit-rich areas than other areas of the city, thereby impacting new transit-oriented development projects.

Table 6: ARO Projects Compared to Buildings Constructed Between 1999 and 2013

\begin{tabular}{|c|c|c|c|c|c|}
\hline \multirow{2}{*}{ Development Category } & \multirow{2}{*}{ Total } & \multicolumn{2}{|c|}{ Half Mile of Metro Station } & \multicolumn{2}{|c|}{$\begin{array}{c}\text { Not within Half Mile of Metro } \\
\text { Station }\end{array}$} \\
\cline { 3 - 6 } & Number & $\begin{array}{c}\text { \% of Total } \\
\text { Projects/Buildings }\end{array}$ & Number & $\begin{array}{c}\text { \% of Total } \\
\text { Projects/Buildings }\end{array}$ \\
\hline Buildings 1999-2013 & 26,144 & 1,486 & $6 \%$ & 24,658 & $94 \%$ \\
\hline ARO Projects & 153 & 110 & $72 \%$ & 43 & $28 \%$ \\
\hline $\begin{array}{c}\text { Ratio of New Buildings } \\
\text { to ARO Projects }\end{array}$ & $171: 1$ & $14: 1$ & & $573: 1$ & \\
\hline
\end{tabular}

There is one limitation that undermines the credibility of the suggestion that the ARO has affected development activity in areas adjacent to transit stations. The Central City 
area is the only area of the city with a significant concentration of ARO projects in proximity to transit. ARO projects are relatively dispersed within half-mile buffers in other areas of the city. This suggests that ARO projects have likely not affected developed activity within transit adjacent areas for the city as a whole. It is much more likely that the ARO has affected development activity within the Central City area of Downtown Los Angeles.

The concentration of ARO projects to buildings constructed between 1999 and 2013 is significantly higher in the Central City area than other areas of the city. For one ARO project there were approximately 1.5 new buildings constructed between 1999 and 2013 (see table 7 below). Within a half-mile radius of Metro stations, this ratio is $1: 1$. Outside of this radius, the ratio is $9: 1$. This geographic concentration justified a development trend analysis specific to the Central City area.

Table 7: ARO Projects Compared to New Development, Central City Area

\begin{tabular}{|c|c|c|c|c|c|}
\hline \multirow{2}{*}{ Development Category } & \multirow{2}{*}{ Total } & \multicolumn{2}{|c|}{ Half Mile of Metro Station } & \multicolumn{2}{c|}{$\begin{array}{c}\text { Not within Half Mile of Metro } \\
\text { Station }\end{array}$} \\
\cline { 3 - 6 } & Number & $\begin{array}{c}\text { \% of Total } \\
\text { Projects/Buildings }\end{array}$ & Number & $\begin{array}{c}\text { \% of Total } \\
\text { Projects/Buildings }\end{array}$ \\
\hline Buildings 1999-2013 & 128 & 74 & $6 \%$ & 54 & $94 \%$ \\
\hline ARO Projects & 86 & 80 & $93 \%$ & 6 & $7 \%$ \\
\hline $\begin{array}{c}\text { Ratio of New Buildings } \\
\text { to ARO Projects }\end{array}$ & $1.5: 1$ & $1: 1$ & & $9: 1$ & \\
\hline
\end{tabular}


Figure 10: Central City ARO and Building Age Summary

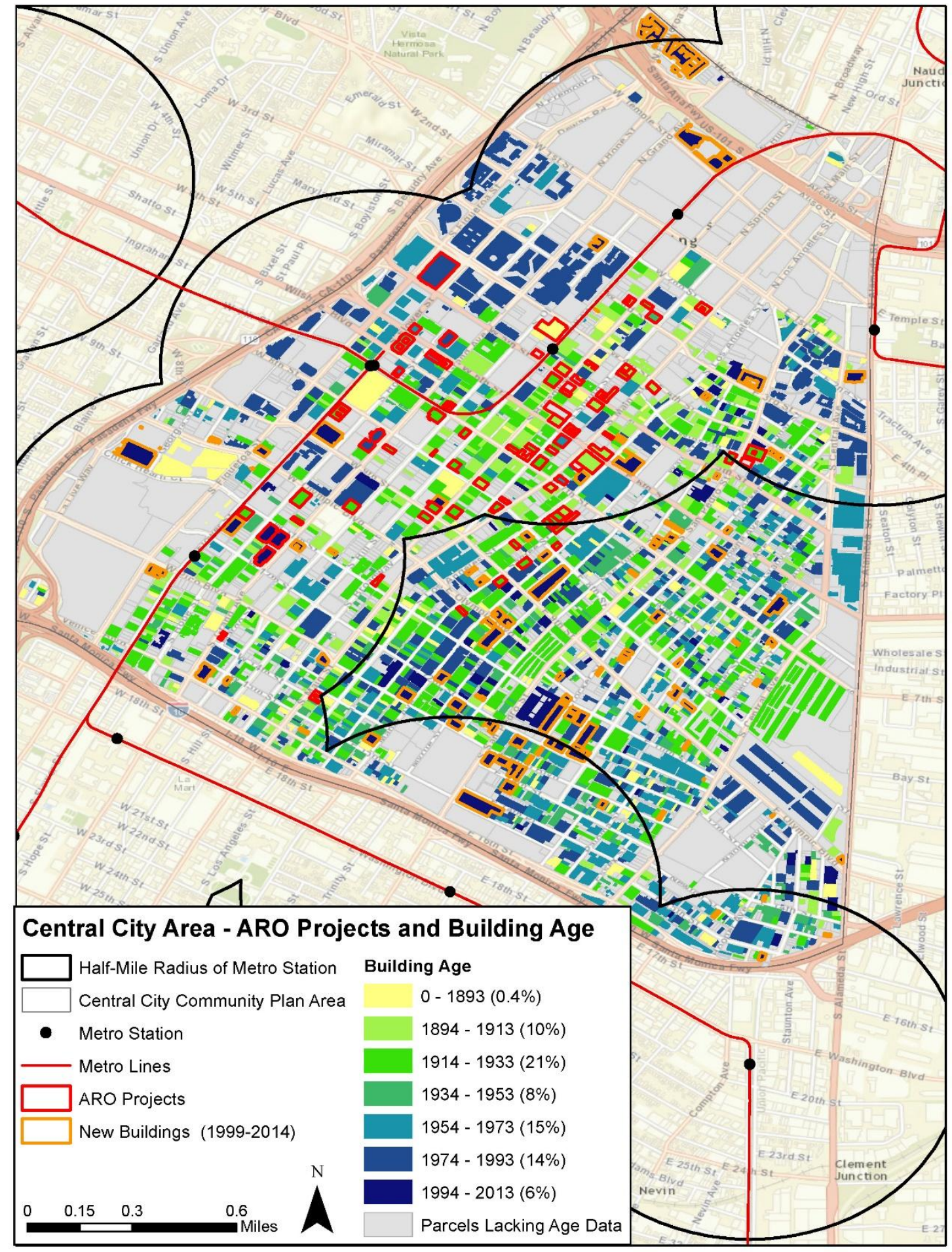




\subsection{Development Trend Analysis - Central City Area}

\subsubsection{General Observations}

Figures 11 and 12 (located on page 72) illustrate development trends in the Central City area from 1985 to 2013 . Fluctuations in development during this time period likely correlate to times of economic growth and downturn, among other factors. In figure 11, the trend line for new development indicates that overall, development activity has decreased from 1985 to 2013 . New development appeared to sharply decline in the midto-late 1990s. Figure 11 also illustrates ARO conversion trends in the Central City area between 1999 and 2013. ARO projects fluctuate during this time period. The trend line for ARO projects indicates that conversions gradually increased from the ARO's adoption until around 2005. From 2005 to 2010, ARO projects steadily decreased. Only three ARO projects occurred between 2010 and 2013. Figure 12 illustrates development trends post-1999 using a trend line that combines ARO projects with new development. According to this trend line, general development activity (ARO projects and new development) increased from 1999 to 2008, then sharply declined from 2009 to 2012. In 2012 all development activity appeared to slightly increase.

\subsubsection{Relationship between new development and ARO projects}

The trend lines for new development and ARO projects share some commonalities. Between 1999 and 2005, new development and ARO projects increased. The delta between new development and ARO projects appears to be closing between 1999 and 2005, suggesting that the ARO created a greater market opportunity for adaptive reuse among the development community. The ARO helped make adaptive reuse a more feasible option for developers, and they took full advantage of the opportunity. Between 
1999 and 2007 both types of development increase at a similar rate - new development has a 2:1 ratio with ARO projects. New development and ARO projects have maintained a close relationship in Downtown Los Angeles since the ordinance was adopted.

According to figure 12, all development activity (ARO projects and new construction) significantly increased after the ARO was adopted, suggesting that the ARO contributed to a renewed development interest in the downtown area. This supports claims the ARO has helped to facilitate the revitalization of Downtown Los Angeles (Bell, 2014; Los Angeles Department of City Planning, 2014d, pp. 9-13; The Partnership for Building Reuse, 2013, pp. 9, 26, 39; Bullen \& Love, 2009, pp. 355-358; Mayor's Office of Economic Development, 2004, p. 22; Bernstein, 2012, p.253). In 2013, ARO projects and new development appears to increase slightly. Further data and analysis is required to examine development trends in the past two years, from 2013 to 2015. One could hypothesize, however, that this tight relationship will continue in the future, until the inventory of buildings suitable for adaptive reuse is exhausted.

Development activity, for both new development and ARO projects, appears to be strongly associated with times of economic downturn. Around the time of the 2008 recession, all development activity (new development and ARO projects) decreases dramatically. The 2008 recession impacted adaptive reuse in the same way it impacted new construction. However, it does appear that the ARO helped to soften-the-blow of the 2008 economic downturn for the development community. This inference can be drawn because of several observations. First, between 2008 and 2013 the delta between ARO projects and new development closes slightly. This indicates that between 2009 and 2013, the relationship between ARO projects and new development grew stronger. Second, the 
ratio of ARO projects to new development decreases from 2:1 in the years before 2008, to 1:1 after 2009. Before 2008, new development was generally twice that of ARO projects, yet after 2008 , new development was generally equal in number to ARO projects. In 2011, ARO projects outnumbered new development by two to zero.

The ARO may have been partially responsible for keeping development activity in Downtown Los Angeles afloat after the 2008 economic downturn. Despite the inherent financial risks associated with adaptive reuse, developers could have considered ARO projects as a safer investment to new construction. In addition, because many ARO projects involved the reuse of historic resources, developers utilized historic preservation financial incentives to offset the cost of reuse, including Federal Historic Rehabilitation Tax Credits and the Mills Act (Bernstein, 2012, p. 260). Similar financial incentives may have not been available for new development projects.

Table 8: ARO Projects and New Development, 1985 to 2013

\begin{tabular}{|l|l|l|l|l|}
\hline Year & $\begin{array}{l}\text { New } \\
\text { Development }\end{array}$ & Year & $\begin{array}{l}\text { ARO } \\
\text { Projects }\end{array}$ & $\begin{array}{l}\text { New } \\
\text { Development }\end{array}$ \\
\hline 1985 & 35 & 1999 & 0 & 10 \\
\hline 1986 & 24 & 2000 & 3 & 8 \\
\hline 1987 & 17 & 2001 & 2 & 11 \\
\hline 1988 & 21 & 2002 & 7 & 13 \\
\hline 1989 & 44 & 2003 & 7 & 15 \\
\hline 1990 & 24 & 2004 & 4 & 8 \\
\hline 1991 & 34 & 2005 & 20 & 13 \\
\hline 1992 & 23 & 2006 & 11 & 11 \\
\hline 1993 & 12 & 2007 & 14 & 17 \\
\hline 1994 & 6 & 2008 & 2 & 15 \\
\hline 1995 & 22 & 2009 & 2 & 3 \\
\hline 1996 & 13 & 2010 & 0 & 1 \\
\hline 1997 & 17 & 2011 & 2 & 0 \\
\hline 1998 & 19 & 2012 & 0 & 1 \\
\hline 1985 & 35 & 2013 & 1 & 2 \\
\hline
\end{tabular}


Figure 11: Central City Development Trends

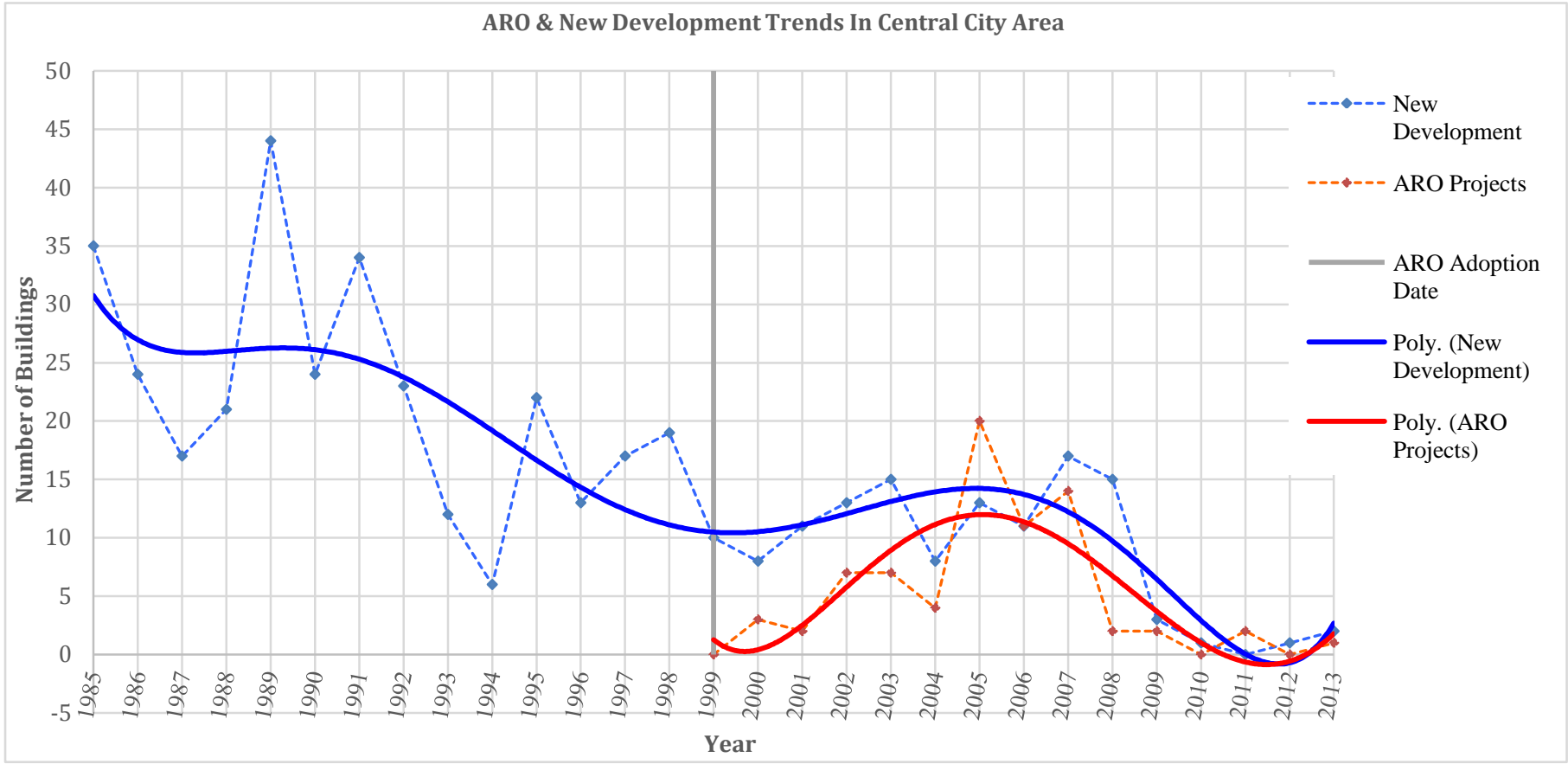

Figure 12: Central City Development Trends, New Development and ARO Projects

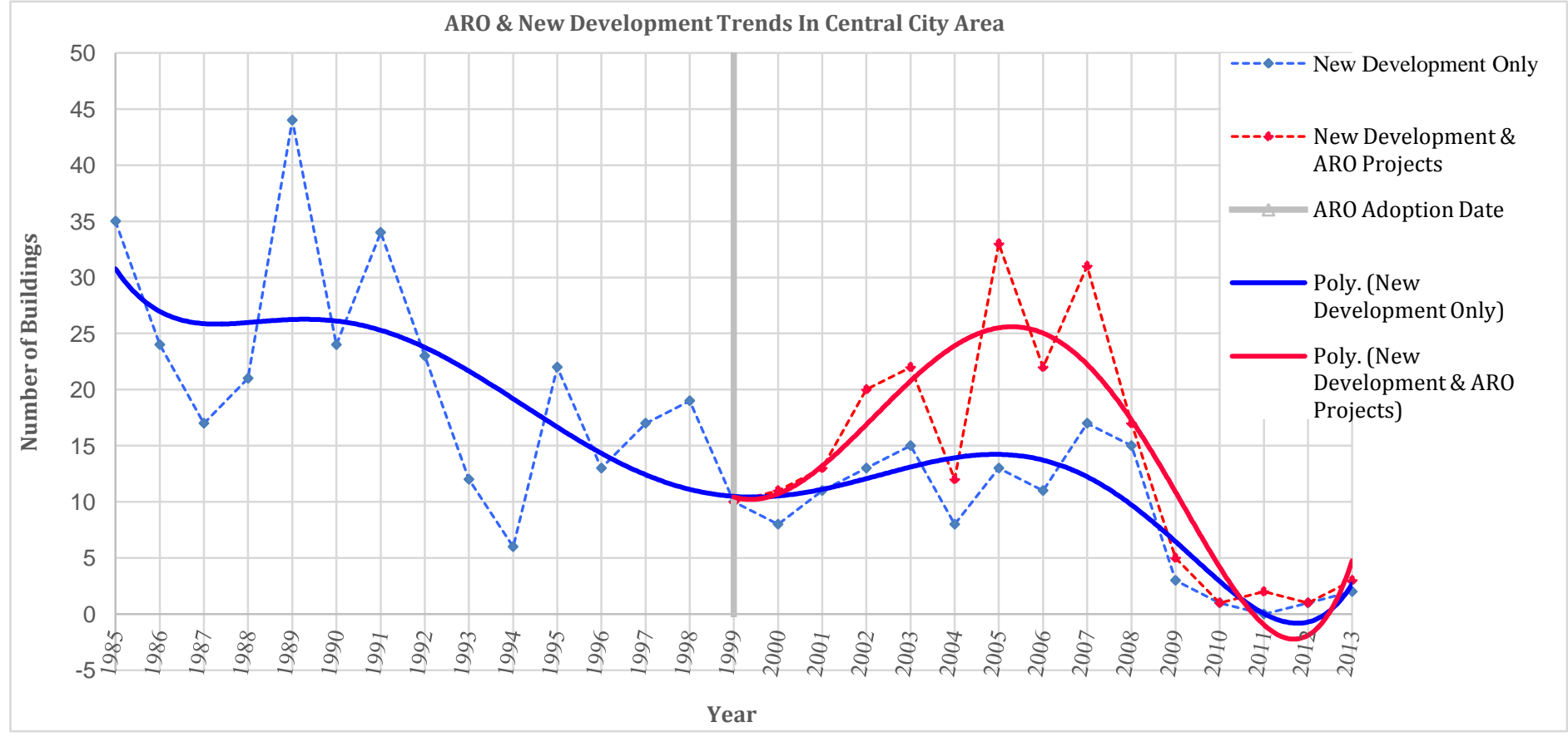




\section{CONCLUSIONS}

\subsection{Contributions to Smart Growth}

Before the adoption of the ARO, development activity in Downtown Los Angeles was on a negative trajectory. Rates of new construction had been steadily declining since 1985 , and in the 1990s office buildings were rarely more than $85 \%$ occupied (Shigley, 2009). This all changed in 1999 around the time of the adoption of the ARO. After 1999, rates of new construction increased slightly. During the mid-2000s, development activity (ARO projects and new construction) in the Central City area reached a level that had not been experienced since the late 1980s. It appears that the ARO was responsible for accelerating development activity, likely by increasing downtown's residential population. In the Central City area alone, occupied housing units increased from 11,713 in 2000 to 20,495 in 2013 (U.S. Census Bureau, 2000; U.S Census Bureau, 2013).

These findings support suggestions that the ARO was the catalyst for the revitalization of Downtown Los Angeles. Alan Bell, the Deputy Director of Planning for the City of Los Angeles, and Ken Bernstein, a preservation planner with the City of Los Angeles, both claim that the ARO succeeded in spurring residential and economic growth to a degree that was unmatched by prior revitalization efforts (Bell, 2014; Bernstein, 2012, p. 256). Shipley (2009) also argues that the ARO achieved greater levels of revitalization than the large redevelopment projects in the 1980s and 1990s intended to reverse downtown disinvestment.

The ARO increased the residential population, access to services, and overall development activity in Downtown Los Angeles. Increasing land use densities and overall activity in this area arguably helped to reduce vehicle miles travelled, as 
Downtown Los Angeles is the focal point for the regional transportation system. Before the ARO, Downtown Los Angeles had not boosted a sizeable residential population. Downtown had relatively few full-time residents, yet some 500,000 daytime workers commuted to and from the area each day (Shigley, 2009), leaving streets deserted at night (Bell, 2014). By increasing the residential population base and commensurate services and amenities, the ARO helped reversed this, fostering an urban area that now enjoys 24hour activity. In this context, the ARO helped achieve its purpose to reduce vehicle trips through the creation of a mixed-use downtown environment well served by transit.

The ARO was responsible for creating a more mixed-use environment in Downtown Los Angeles without changing underlying zoning designations. A zone change is a complex and time intensive process that requires environmental review and approval from the Planning Commission and the legislative body (Fulton \& Shigley, 2012, p. 150). Zone changes may necessitate a general plan amendment if the change creates an inconsistency with the general plan (Fulton \& Shigley, 2012, p. 151). The ARO permits a project containing residential uses if the project is located within a commercial or highdensity residential zoning district (Mayor's Office of Economic Development, 2004, p. 10). ARO projects typically entirely consist of residential uses, sometimes mixed with commercial condominiums and ground-floor retail space. Without the ARO, allowing residential uses in a non-residential zoning district would be considered "spot zoning", a practice that is widely abused and legally vulnerable (Fulton \& Shigley, 2012, p. 151). Zone changes and spot zoning is a contentious process that is often shot down because of NIMBYism, even if the proposal has merit. The ARO avoided this contention and 
fostered a greater mix of land uses in an area served by regional transit. This was undoubtedly beneficial from both an economic and environmental standpoint.

The ARO was partly responsible for an increased level of infill development activity downtown. Development in an area served by public transportation is inherently more sustainable than development in greenfield areas located away from transit. There are fewer vehicles miles travelled, and less development encroaching into natural areas on the urban periphery. In addition, the majority of ARO projects have far lower ratios of parking spaces to residential units than what is typically found in new developments. Because the ARO waived parking requirements, new on-site parking spaces were rarely added to buildings undergoing reuse. Many ARO buildings in Downtown Los Angeles have no on-site parking spaces. The ARO increased Downtown Los Angeles's residential population without an accompanying increase in parking spaces; further optimizing the impact the ARO has had on transit-oriented growth.

\subsection{Softening the Impact of the Recession}

The ARO appears to have softened the impact of the 2008 economic downtown for the development community. From 1999 to 2008, rates of new development in the Central City area remained relatively constant, with an average of approximately twelve new buildings constructed a year. After 2008, rates of new development decreased dramatically, from fifteen buildings constructed in 2008 to three buildings constructed in 2009. ARO projects also dropped from fourteen projects in 2008 to two projects in 2009 . In the years after the recession (2009-2013), the number of ARO projects became almost neck-and-neck with the number of new developments. During this time, the average ratio of new developments to ARO Projects was 1:1. Before the recession, from 1999 to 2009, 
the average ratio was 2:1. In 2011 the number of ARO projects even surpassed new development by two to zero.

In the years immediately following the 2008 economic downturn, the development community could have shifted their focus from high-rise, multi-use construction to a safer alternative - the reuse of the existing building stock. Although adaptive reuse is oftentimes more costly than new construction, the financial risks could have been less significant after the 2008 economic downturn. If this is true, the ARO is partly responsible for maintaining development activity in Downtown Los Angeles during a period when development declined significantly throughout the nation.

\subsection{Avoided Environmental Impacts}

The ARO contributed to sustainable development by fostering urban growth in transit-adjacent areas, especially in Downtown Los Angeles, an area with easy access to the regional transit network. By recycling blighted buildings, the ARO breathed life into an existing urban area without the environmental impacts associated with new development. Adaptive reuse is a more environmentally sustainable alternative to demolition and new construction. It avoids the environmental impacts inherent in both activities; including the carbon emitted during the construction, demolition, and material preparation process (Preservation Green Lab, 2011, p. 20; Yung \& Chan, 2012, p. 352; Lucuik, Huffman, Trusty, \& Prefasi, 2010, p. 7; Merlino, 2011, pp. 79-80; Bullen \& Love, 2010, p.216). If new development were to take the place of these buildings, it would have likely resulted in significant environmental impacts, not to mention the irreversible loss of treasured historic landmarks. 
Although it is plausible that these buildings could be demolished and replaced with larger, more intensive buildings, the majority (67\%) are designated historic resources listed on the National Register of Historic Places, the California Register of Historic Places and local registers. Historic resource designation makes demolition a less-likely scenario, although it does not guarantee it. Development projects that involve the demolition of buildings listed or determined eligible for National Register or California Registers of Historic Places are subject to environmental review under the California Environmental Quality Act (CEQA). CEQA requires the consideration of alternatives to demolition, including preservation and adaptive reuse (Association of Environmental Professionals, 2014, p.194; Los Angeles Conservancy, n.d.). Local designation as a Historic-Cultural Monument allows the Los Angeles Cultural Heritage Commission to object to demolition (Los Angeles Conservancy, n.d.).

Historic resource designation protected these buildings from demolition to a certain degree. Still, most had been left vacant, some for decades (Bell, 2014). Without the ARO, these buildings could have remained vacant until the point of severe structural degradation, thereby possibly necessitating demolition (Shigley, 2009). Although it is generally not favorable, historic buildings sometimes must be demolished because of decay (Aikins, 2012, p.19; Flynn, 2007, p.131). In this context, adaptive reuse could have served as an effective mitigation against the potential environmental impacts resulting from demolition and reconstruction. 


\subsection{Historic Preservation}

The ARO has served as an effective tool for historic preservation. Citywide, $42 \%$ of buildings reused with ARO assistance are designated historic resources. Approximately $22 \%$ of ARO buildings are listed in the National Register of Historic Places, $12 \%$ are listed in the California Register of Historic Places, and 8\% are listed in the Los Angeles local register. Approximately half of the buildings listed in the National Register of Historic Places are historic district contributors, while the other half are individual resources. The majority of buildings on the California register (85\%) and buildings in the local register $(69 \%)$ are individual resources, meaning they are not part of a historic district. As previously noted, many of these buildings may have been demolished from neglect had the ARO not been adopted (Shigley, 2009).

ARO projects sometimes involved conversions to treasured historic landmarks. The Continental Building, a beaux-arts style high rise in Downtown Los Angeles, was converted to apartments between 1999 and 2000. Constructed in 1904, the Continental Building was the tallest building in Los Angeles for more than fifty years (Los Angeles Conservancy, n.d). Between 2004 and 2006, the Eastern Columbia building, also located in Downtown Los Angeles, was converted to live/work lofts. The Eastern Columbia building, constructed in 1930, is a picturesque representation of the art deco style of architecture, flush with colorful ornamentation. The conversion project largely restored the integrity of the building, earning a Conservancy Preservation Award in 2008 from the Los Angeles Conservancy (Los Angeles Conservancy, n.d.1). 
Figure 14: Continental Building (Laskey, n.d)

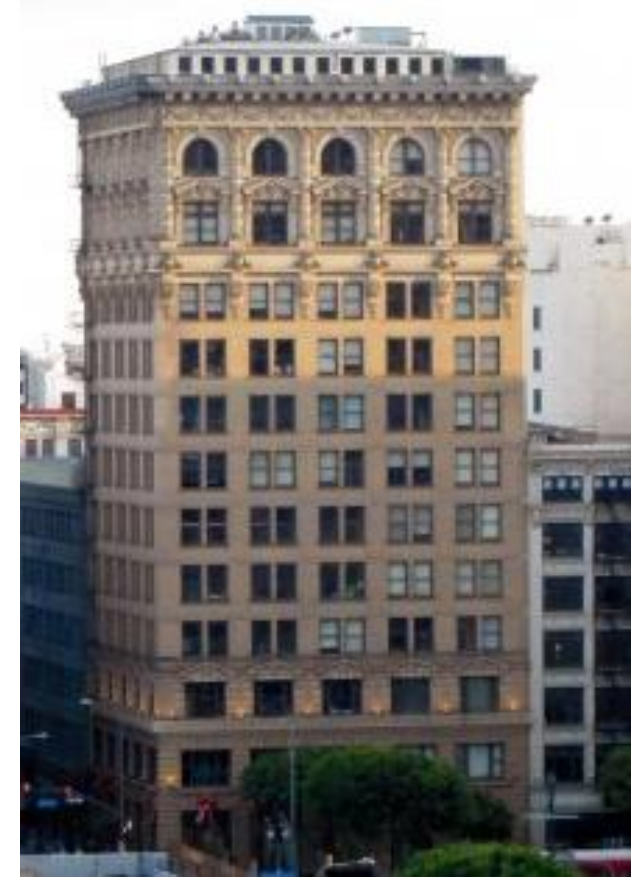

Figure 13: Eastern Columbia Building (Fine, n.d)

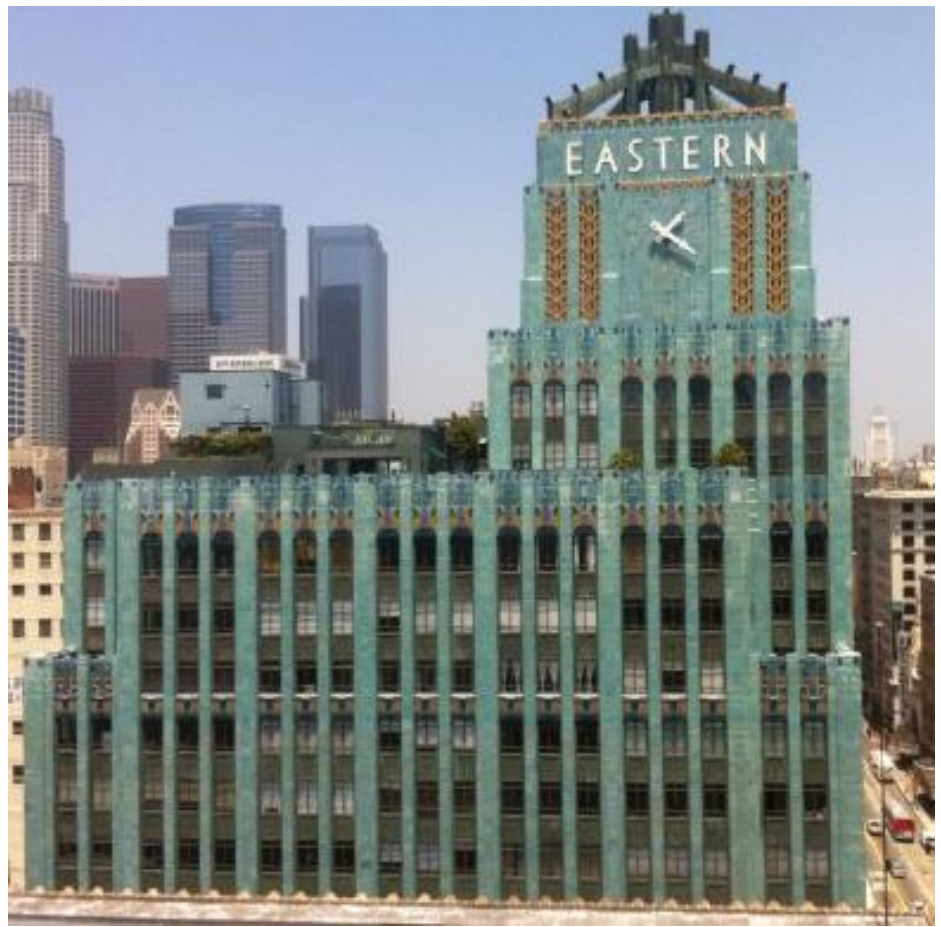

The ARO also facilitated the reuse of buildings ineligible for designation per national, state, or local guidelines, but possess architectural character. In some cases, reuse projects involved innovative additions to character buildings, reinterpreting the historic fabric to create an interesting visual effect. One example is a grouping of industrial warehouses located in an area of the downtown Arts District known as the "Barker Block", located along the 400 block of South Hewitt Street. From 2005 to 2013, seven warehouses in this area that previously housed a furniture factory (Brasuell, 2013) were converted into 297 live/work condominiums and three commercial condominiums (Los Angeles Department of City Planning, 2005). With the brick façade of these buildings largely kept intact, new additions and renovations augment the existing historic structures with contemporary 
architectural features. This interesting aesthetic effect could arguably not be captured with new construction.

Figure 15: Primary facade of Barker Block Warehouse No.1 (Photographer unknown, n.d)

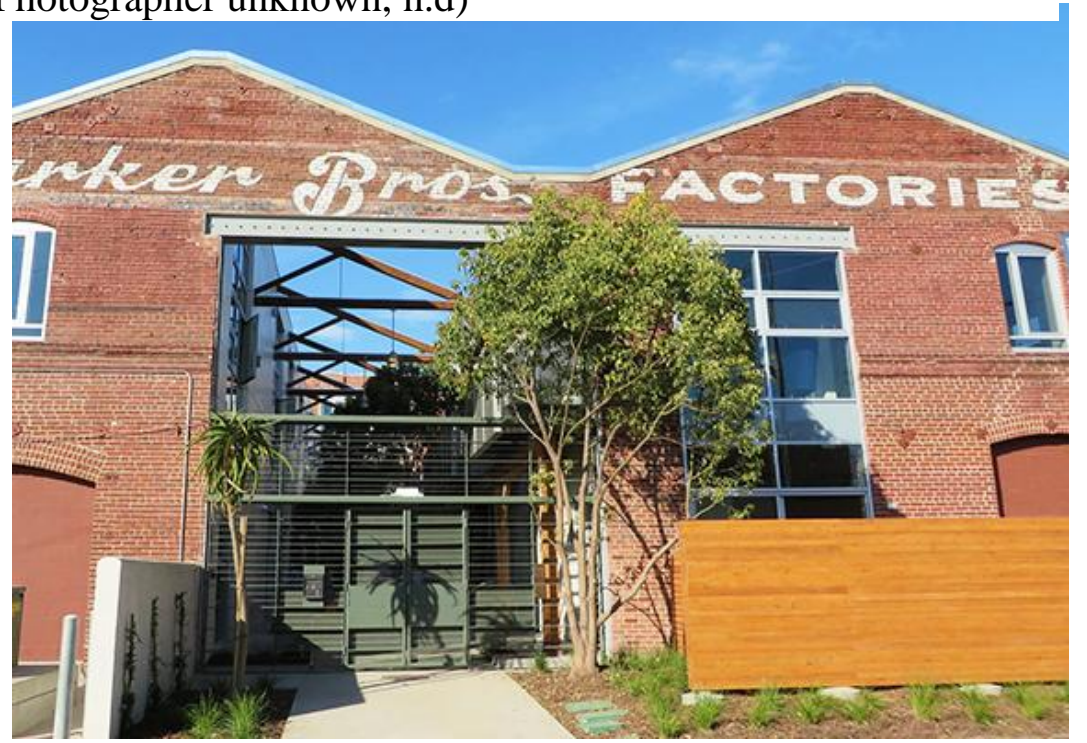

Figure 16: View of Barker Block Warehouse (Google Maps, 2014)

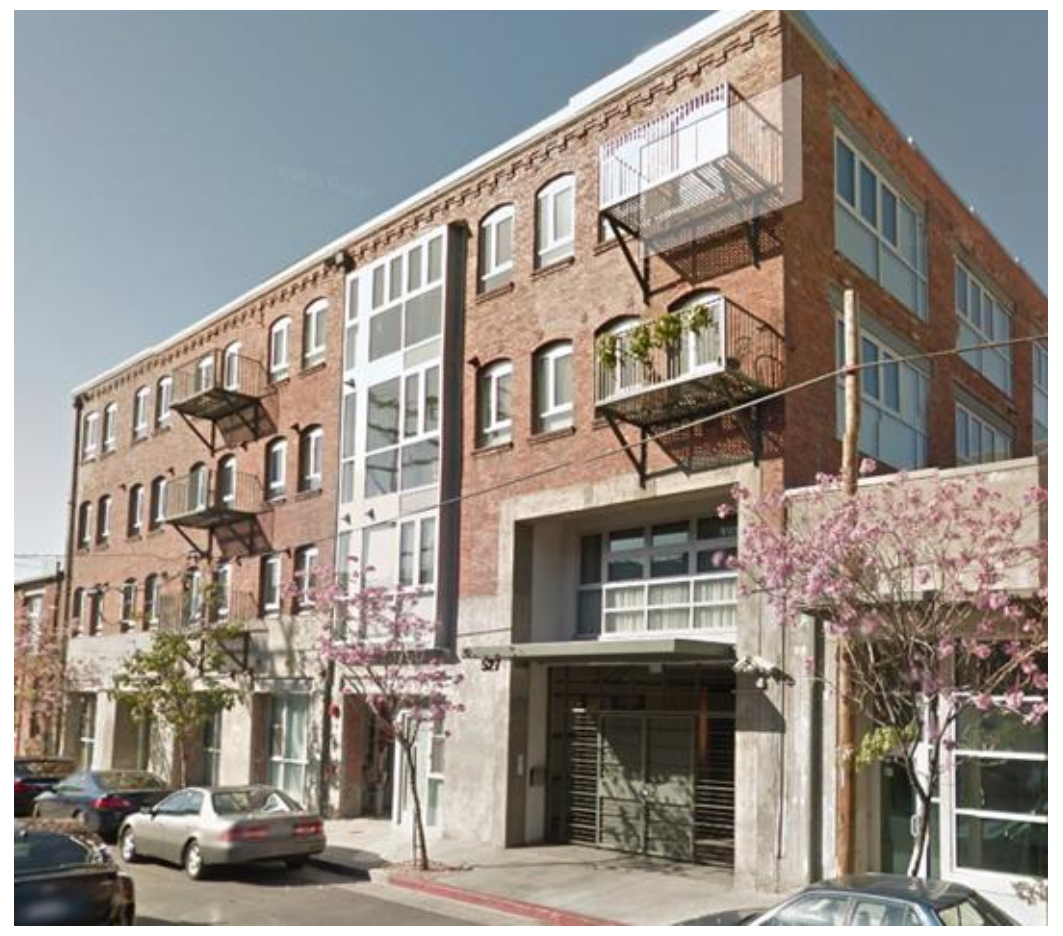




\subsection{The Future of Adaptive Reuse in Los Angeles}

The future of adaptive reuse in Los Angeles will involve the conversion of different types of buildings than the downtown high-rises and warehouses that have characterized the bulk of the program's application. As noted by Brown (2008), the majority of the easily developed inventory in Downtown Los Angeles was reused in the early years of the program (p.70). Much of the buildings that remain applicable to the ARO are more difficult to restore, and they require greater consideration from the Office of Historic Preservation, Department of Building and Safety, and City Planning Department (Brown, 2009, pp. 70-71). However, as buildings turn 50 years in age an increasingly high number will be eligible for ARO incentives. In a sprawling metropolitan area like Los Angeles, there will be a seemingly limitless supply of buildings suitable for reuse. Los Angeles may experience growth in the reuse of mid-century modern buildings and other buildings that are often not as highly valued by preservationists as the decorative beaux-arts or art deco buildings that were reused downtown. As newer buildings become eligible for reuse, there will likely be interesting debates on the merits of their retention.

The future of adaptive reuse in Los Angeles will also likely witness the spread of the ARO into different areas of the city. As Los Angeles grows and modernizes, the pressure to revitalize other areas of the city will increase. The report Learning from Los Angeles (2013) conducted a study on vacant office space in ARO incentive areas and found a substantial amount of vacant office space in the Wilshire Corridor and Koreatown Redevelopment Area, two areas that are highly transit accessible (p.17). There is an untapped opportunity in both areas to meet growing demands for housing and office space through adaptive reuse (The Partnership for Building Reuse, 2013, p. 17). If 
properly applied, Los Angeles can continue to demonstrate how to simultaneously accommodate transit-oriented growth, preserve architectural heritage, and avoid the environmental impacts of new construction.

\subsection{Areas of Further Research}

\subsubsection{Commercial conversions}

The ARO has been instrumental in facilitating residential conversions. ARO projects have predominately involved the conversion of existing buildings to support apartments, condominiums, and live/work units. In limited cases, the ARO has allowed for commercial condominiums and ground floor retail space. Because the ARO has been limited in its conversion scope, it has not fully capitalized on demands for office space. The ARO provides projects with by-right entitlement if they include rental residential units (Mayor's Office of Economic Development, 2004, p. 10). If a project is strictly limited to commercial uses, ARO incentives will not apply. Interviewees who specialize in adaptive reuse in Los Angeles have noted that the ARO should allow for greater commercial conversions (The Partnership for Building Reuse, 2013, pp. 7, 26, 33). This potentially could optimize the effectiveness of the ARO in reducing building vacancies, as it could take advantage of demands for office and other commercial space. Greater research is needed to determine how the ARO can be modified to facilitate commercial conversions, buildings suitable for commercial conversions, and areas where vacancies and demands for office space are high. Such areas could be appropriate candidates to be designated as ARO incentive areas. 


\subsubsection{Changing urban densities}

This study did not quantify changes in land use or population densities that have occurred in the Central City area as a result of the ARO. This analysis would be key in answering if the ARO has hindered or contributed to the densification of areas adjacent to transit stations. A potential density analysis could involve comparing key density variables of case study blocks within the Central City area before and after the adoption of the ARO. Case study blocks selected for comparison would display similar characteristics, including geographic unit (census tract or block), presence of ARO projects, and proximity to transit. To measure density, three measurements could be used: floor-area ratio, dwelling units, and population. Conversely, census data could also be used to determine changes to urban density.

\subsubsection{Complete streets in Downtown Los Angeles}

This study aimed to examine how the ARO contributed to the goals of smart growth only from the perspective of transit-oriented development. It did not examine if the ARO contributed to a more pedestrian and cyclist friendly environment in downtown or any other incentive area. The ARO increased mixed residential and commercial uses in areas adjacent to transit stations, and it spurred new development in Downtown Los Angeles, an area that is highly transit-accessible. Dense, mixed-use development in walking distance to transit is one method of reducing greenhouse gas emissions from travel. However, the streets and sidewalks must also safely accommodate modes of travel other than the automobile. In Downtown Los Angeles in particular, it is unclear whether or not increased development activity (new construction and ARO projects) has resulted in commensurate improvements to pedestrian and bicycle facilities. Although many ARO 
buildings lack on-site parking spaces, residents may prefer their automobile over transit. An additional study could examine if the streets and sidewalks adjacent to ARO projects sufficiently accommodate active modes of transportation.

\subsubsection{Vehicle miles traveled}

The ARO contributed to transit-oriented growth by converting vacant building space to residential and commercial space in areas adjacent to transit, and by accelerating infill development activity in transit rich Downtown Los Angeles. Based on these conclusions, one can infer that the ARO helped to reduce vehicle miles traveled, and researchers and planners have made this inference (Bell, 2014; Bullen \& Love, 2009, pp. 355-358). However, this inference is not supported by quantitative data or analysis. Greater research is required to determine if vehicle trips increased or decreased after the adoption of the ARO. Because of the sheer size of Los Angeles, it may be difficult to pinpoint the ARO has a contributing factor to any observed drop in vehicle miles travelled.

\subsubsection{Affordability and gentrification}

This thesis primarily discussed the contribution of the ARO to sustainable development from an environmental standpoint. To a certain degree, the ARO has met the social objectives of sustainability, because it retained historic resources and it helped to regenerate a former blighted area. However, critics have argued that the ARO has not produced enough affordable housing, and that it has the potential to displace downtown's lower-income residents (Bullen \& Love, 2009, p. 355; Bernstein, 2012, pp. 262-263; Young, 2009). At the time of the ARO's adoption, the City of Los Angeles was desperate for any sort of downtown investment. The area was in dire need of revitalization, and ARO incentives were designed to be as advantageous as possible (Young, 2009, p. 706). 
As a result, few affordable units were created in ARO projects. According to Bernstein (2012), as of 2012 fewer than $10 \%$ of downtown ARO housing units have been affordable (p. 263).

Critics have also suggested that the revitalization of downtown spurred by the ARO may result in the displacement of low-income residents. Downtown Los Angeles contains a high concentration of single-room-occupancy (SRO) hotels that rent to lower-income tenants. Inside the downtown incentive area, ARO incentives are applicable to residential-to-residential conversions, while such conversions are not permitted in other incentive areas, unless the building has been "completely and continuously unoccupied from March first, 2002 (Section 4, Adaptive Reuse Incentive Areas Specific Plan \& Section 12.24-X,1(a), Citywide Adaptive Reuse Ordinance as cited in Mayor's Office of Economic Development, 2004, p.15)." Based on a review of literature, it is unclear if the ARO has been used for the conversion of existing residential buildings. According to Ken Bernstein (2012), a planner for the City of Los Angeles, the ARO has not directly displaced any low-income residents, as it primarily has been used for previously vacant buildings (p. 262). Regardless, critics point out that the area's revitalization resulted in instances where occupied residential buildings (including SRO hotels) were converted to market-rate housing (Bullen \& Love, 2009, p.357; Bernstein, 2012, p. 262). Gentrification concerns have prompted non-profit housing organizations to advocate to reform the ARO to provide incentives for affordable housing (Bullen \& Love, 2009, p. $355)$.

In existing urban areas, smart growth initiatives often come at the expensive of the working class and urban poor. Targeted transit-oriented growth and revitalization efforts 
in historically middle-to-lower-income areas can serve to displace residents vulnerable to fluctuations in property values, renters in particular. Rent increases typically associated with revitalization and renewed development interest may cause existing vulnerable residents and businesses to leave the area (Kushner, 2002; Listokin, Listokin, \& Lahr, 1998, pp. 464-467). Critics warn that such gentrification can arise from growth policies that encourage transit-oriented infill development (Kushner, 2002) and from historic preservation based revitalization efforts (Listokin, Listokin, \& Lahr, 1998, pp. 464-467). Both are key strategies of the smart growth movement, which is touted as an inherently sustainable form of urban development, from an environmental, economic, and equitable standpoint. With the passing of the Sustainable Communities and Climate Protection Act (SB 375) in 2008, urban regions throughout California have accepted smart growth as a key method of reducing greenhouse gas emissions. Regional transit-oriented growth efforts are already causing concerns of gentrification, namely in San Francisco, where local politicians have proposed a moratorium on new market-rate residential development in the historically working-class Mission District because of gentrification concerns (Wildermuth, 2015). Although Los Angeles does not share the same geographic constraints or real estate values, targeted growth and revitalization efforts potentially could result in similar concerns in the years to come.

\subsection{Final Thoughts}

Leveraging the historic assets of an urban environment can be an effective first step in targeting growth and investment to a particular area. Through a relatively simple set of incentives, the Los Angeles Adaptive Reuse Ordinance (ARO) helped to regenerate a blighted urban area with strong access to a regional public transportation system. The 
conversion of vacant and underutilized buildings in Downtown Los Angeles appears to have acted as a catalyst for infill development activity, helping to implement local and regional strategies aimed to encourage transit-oriented growth. Further questions remain about the smart growth and sustainability implications of the ARO; whether it actually has helped to reduce vehicle miles traveled, if it could allow for even greater flexibility in building reuse, if the public realm surrounding ARO projects accommodates active modes of transportation, if it has resulted in gentrification, and so forth. Despite these questions, the ARO has undoubtedly contributed to the goals of smart growth and sustainable development. The ARO helped to accommodate and spur transit-oriented growth while preserving a treasured collection of historic resources, many of which were likely to be demolished if not for ARO incentives. 


\section{BIBLIOGRAPHY}

AB 1358. (2008). California State Assembly.

Aikins, D. B. (2012). Demolition of Historic Structures: CEQA Compliance and Tactics. Cal Real Property Journal, 30(2), 19-28.

Association of Environmental Professionals. (2014). 2014 CEQA Statutes and

Guidelines. California Natural Resources Agency: Sacramento, CA. Retrieved 21 February 2015 from: http://resources.ca.gov/ceqa/

Austin, R. (1988). Adaptive Reuse: Issues and Case Studies in Building Preservation. New York, NY: Van Nostrand Reinhold Company.

Barthel-Bouchier, D. (2013). Cultural Heritage and the Challenge of Sustainability. Walnut Creek, CA: Left Coast Press.

Bedsworth, L., Hanak, E., \& Kolko, J. (2011). Driving Change: Reducing Vehicle Miles Traveled in California. San Francisco, CA: Public Policy Institute of California.

Been, V., Ellen, I., Gedal, M., Glaeser, E., \& McCabe, B. (2014). Preserving History or Hindering Growth? The Heterogeneous Effects of Historic Districts on Local Housing Markets in New York City. New York, NY: NYU Furman Center.

Bell, A. (2014). Application form - 2014 Guangzhou International Award for Urban Innovation. Unpublished Document.

Bernstein, K. (2012). A Planning Ordinance Injucts New Life into Historic Downtown. In D. Sloane, Planning Los Angeles (pp. 253-264). American Planning Association.

Birch, E., \& Roby, D. (1984). The Planner and Preservationist: an Uneasy Alliance. Journal of the American Planning Association, 2(50), 194-207. 
Boarnet, M. (2012). Back to the Future in Transportation Planning. In D. Sloane, Planning Los Angeles (pp. 147-162). American Planning Association.

Bottles, S. (1987). Los Angeles and the Automobile: The Making of the Modern City. Berkeley, CA: University of California Press.

Brasuell, J. (2013). Barker Block Moving on Arts District's Only New For-Sale Units. Retrieved May 25, 2015, from Curbed LA:

http://la.curbed.com/archives/2013/04/barker_block_moving_on_arts_districts_on ly_new_forsale_units.php

Brown, I. (2009). Adaptive Reuse as Economic Development in Downtown Los Angeles: A Resource Guide for Start-up Developers, Community Based organizations, and Stakeholder Groups. Los Angeles, CA: University of Southern California.

Bullen, P., \& Love, P. (2009). Residential Regeneration and Adaptive Reuse: Learning from the Experiences of Los Angeles. Structural Survey, 5(27), 351-360.

Bullen, P., \& Love, P. (2010). The Rhetoric of Adaptive Reuse or Reality of Demolition: Views from the Field. Cities, 4(27), 215-224.

Byrne, P. (2012). Historic Preservation and its Cultured Despisers: Reflections on the Contemporary Role of Preservation Law in Urban Development. George Mason Law Review, 3(19), 665-688.

California Air Resources Board. (2014). Sustainable Communities. Sacramento CA: California Environmental Protection Agency. Retrieved 27 November 2014, from: http://www.arb.ca.gov/cc/sb375/sb375.html 
Cantell, S. (2005). The Adaptive Reuse of Historic Industrial Buildings: Regulation Barriers, Best Practices and Case Studies. Blacksburg, VA: Virginia Polytechnic Institute and State University.

Center for Transit-Oriented Development. (2010). Creating Successful Transit-Oriented Districts in Los Angeles: a Citywide Toolkit for Achieving Regional Goals. Retrieved 27 November 2014 from: http://latod.reconnectingamerica.org/final_report

Cervero, R. (2004). Transit-Oriented Development in the United States: Experiences, Challenges, and Prospects (Report 102). Transportation Research Board. Retrieved 30 April 2015 from: http://onlinepubs.trb.org/onlinepubs/tcrp/tcrp_rpt_102.pdf

Cervero, R., Caldwell, B., \& Cuellar, J. (2012). Bike-and-Ride: Build it and They Will Come. Berkeley, CA: UC Berkeley.

City of Corpus Christi Development Services. (2014). Adaptive Reuse Ordinance. Corpus Christi, TX: City of Corpus Christi.

City of Phoenix Planning and Development Department. (2014). Adaptive Reuse Program. Phoenix, AZ: City of Phoenix.

Curry, M. (2015). Smart Growth America Rates L.A. Metro Complete Streets Policy in Top Ten (Web blog post). Retrieved 26 April 2015 from: http://la.streetsblog.org/category/issues/complete-streets/

Curtis, W. (2008). A Cautionary Tale. Preservation, January/February (2008).

Davis, M. (1992). City of Quartz. London, UK: Vintage. 
Dodman, D. (2009). Blaming Cities for Climate Change? An Analysis of Urban Greenhouse Gas Emissions Inventories. Environment and Urbanization, 21(1), $185-201$.

Downtown Center Business Improvement District. (2014). Downtown LA Market Overview. Los Angeles, CA.

Downtown Los Angeles Neighborhood Council. (n.d.). Complete streets for Downtown Los Angeles. Retrieved April 25, 2015, from http://completestreets.dlanc.com/index.php

Fine, A. (n.d). Photograph of Eastern Columbia Lofts (Photograph). Los Angeles, CA: Los Angeles Conservancy. Retrieved 6 June 2015 from: https://www.laconservancy.org/locations/eastern-columbia-lofts

Flynn, J. (2007). Productive Preservation and the Reinvention of Industrial America. Urban Law, 1(39), 123-147.

Frey, P. (2007). Making the Case: Historic Preservation as Sustainable Development. Unpublished draft white paper presented in advance of the Sustainable Preservation Research Retreat Hosted by the National Trust for Historic Preservation. Retrieved 20 May 2015 from: http://www.preservationnation.org/information-center/sustainablecommunities/additional-resources/DiscussionDraft_10_15.pdf

Frey, P., \& Bowdon, R. (2012). Historic Preservation: Expanding the Planner's Toolbox. American Planning Association PAS Memo(September/October 2012). 
Fulton, W., \& Shigley, P. (2012). Guide to California Planning. Point Arena, CA: Solano Press Books.

Gilderbloom, J., Hanka, M., \& Ambrosius, J. (2009). Historic Preservation’s Impact on Job Creation, Property Values, and Environmental Sustainability. Journal of Urbanism, 2(2), 83-101.

Glaeser, E. (2010). Preservation Follies. City Journal, 2(20), 62-67.

Glaeser, E. (2011). Triumph of the City: How our Greatest Invention Makes us Richer, Smarter, Greener, Healthier, and Happier. New York, NY: Penguin Press.

Glaser, L. (2014). Let's Sustain This: A Review. The Public Historian, 3(36), 130-144. Google Maps. (2014). Google Streetview of Barker Block Warehouse. Retrieved 6 June 2015 from: https://www.google.com/maps/@ 34.04094,118.233781,3a,75y,335.99h,96.54t/data=!3m4!1e1!3m2!1s84z7UZtGyfLS1XV3U 3nhWQ!2e0!6m1!1e1

Greenberg, C. (2015). City Chips Away at Beaux Arts Heart of Manhattan. Architectural Record. Retrieved 31 March 2015 from: http://archrecord.construction.com/news/2015/01/150129-City-Chips-Away-atBeaux-Arts-Heart-of-Manhattan.asp\#.VNzfEKNk8pg.twitter

Guerra, E., Cervero, R., \& Tischler, D. (2012). Half-Mile Circle: Does It Best Represent Transit Station Catchments? Journal of the Transportation Research Board,, 1(2276), 101-109.

Hasenfus, E. (2013). Measuring the Capital Energy Value in Historic Structures. Philadelphia, PA: University of Pennsylvania. 
Ireland, D. (2008). New tricks with old bricks. The Empty Homes Agency, London.

Jackson, K. (1985). Crabgrass Frontier : The Suburbanization of America. New York, NY: Oxford University Press.

Jacobs, J. (1961). The Death and Life of Great American Cities. New York, NY: Random House.

Kennedy, C., Steinberger, J., Gasson, B., Hansen, Y., Hillman, T., Havranek, M., Mendez, G. V. (2009). Greenhouse Gas Emissions from Global Cities. Environmental Science \& Technology, 43(19), 7297-7302.

Koko, J. (2011). Making the Most of Transit. Density, Employment Growth, and Ridership Around New Stations. San Francisco, CA: Public Policy Institute of California.

Krueger, R., \& Gibbs, D. (2008). 'Third Wave'Sustainability? Smart growth and Regional Development in the USA. Regional Studies, 42(9), 1263-1274.

Kushner, J. (2002). Smart Growth, New Urbanism and Diversity: Progressive Planning Movements in America and their Impact on Poor and Minority Ethnic Populations. UCLA Journal of Environmental Law and Policy, 21(1), 45-74

Langston, C. (2008). The Sustainability Implications of Building Adaptive Eeuse. . CRIOCM 2008 International Research Symposium on Advancement of Construction Management and Real Estate. Beijing: The Hong Kong Polytechnic University.

Laurie, J. (2008). Historic Preservation and Cluster Based Economic Development. Economic Development Journal, 1(7), 38-46. 
Laskey, A. (n.d). Photograph of Continental Building (Photograph). Los Angeles

Conservancy. Retrieved 6 June 2015 from:

https://www.laconservancy.org/locations/continental-building

Listokin, D., Listokin, B., \& Lahr, M. (1998). The Contributions of Historic Preservation to Housing and Economic Development. Housing Policy Debate, 13(9), 431-478.

Lindsey, R. (2009). American Carbon - Vulcan Project Maps Nation's Fossil Fuel Emissions in Detail. NASA Earth Observatory. Retrieved 7 June 2015 from: http://earthobservatory.nasa.gov/Features/AmericanCarbon/page1.php

Linton, J. (2015). L.A's Draft Mobility Plan 2035: a Concrete Future Direction? (Web Blog Post). Retrieved 29 April 2015 from: http://la.streetsblog.org/2014/03/14/1-as-draft-mobility-plan-2035-a-concrete-future-direction/

Logan, W. (2013). Implementing Sustainable Communities Strategies at the Municipal Level. Berkeley, CA: UC Berkeley.

Longstreth, R. (1998). City Center to Regional Mall: Architecture, the Automobile, and Retailing in Los Angeles, 1920-1950. Cambridge, MA: MIT Press.

Los Angeles Conservancy. (n.d). Continental Building . Retrieved 25 May 2015 from: https://www.laconservancy.org/locations/continental-building

Los Angeles Conservancy. (n.d.1). Eastern Columbia Lofts. Retrieved 25 May 2015: https://www.laconservancy.org/locations/eastern-columbia-lofts

Los Angeles Conservancy. (n.d.2). How to Save Historic Places. Retrieved 21 February 2015 from: https://www.laconservancy.org/resources/guide/how-save-historicplaces 
Los Angeles County GIS Data Portal. (2014). Countywide Building Outlines - 2014 (GIS Data). Retrieved 1 March 2015 from: http://egis3.lacounty.gov/dataportal/2014/10/16/countywide-building-outlines2014/

Los Angeles County Office of Assessor. (2014). Assessor Parcels - 2014 Tax Roll (GIS Data). Retrieved 1 March 2015 from: http://egis3.lacounty.gov/dataportal/2015/03/10/assessor-parcel

Los Angeles County Metropolitan Transportation Authority. (2014). Metro Complete Streets Policy Draft. Retrieved 28 April 2015 from: http://media.metro.net/projects_studies/sustainability/images/Draft_Complete_Str eets_Policy.pdf

Los Angeles County Metropolitan Transportation Authority. (2014a). First Last Mile Strategic Plan \& Planning Guidelines. Retrieved 29 April 2015 from: http://media.metro.net/docs/sustainability_path_design_guidelines.pdf

Los Angeles County Metropolitan Transportation Authority. (2015). Transit-oriented Development Planning Grant. Retrieved 3 May 2015 from: http://www.metro.net/projects/tod/

Los Angeles County Metropolitan Transportation Authority. (2015a). Joint Development Program. Retrieved 3 May 2015 from: http://www.metro.net/projects/joint_dev_pgm/

Los Angeles Department of City Planning. (n.d.) Community Plans in progress. Los Angeles, CA: City of Los Angeles. Retrieved 5 December 2014 from: http://cityplanning.lacity.org/ 
Los Angeles Department of City Planning. (n.d.a) Land use standards and typical development characteristics. Los Angeles, CA: City of Los Angeles. Retrieved 5 December 2014 from:

http://cityplanning.lacity.org/cwd/framwk/chapters/03/tab31.htm

Los Angeles Department of City Planning. (2001a). Chapter 3 - Land Use. The Framework Element of the Los Angeles General Plan. Los Angeles, CA: City of Los Angeles.

Los Angeles Department of City Planning. (2001b). Wilshire Community Plan. Los Angeles, CA: City of Los Angeles. Retrieved 5 December 2014 from: http://cityplanning.lacity.org/complan/central/wilpage.htm

Los Angeles Department of City Planning. (2001c). Executive Summary. The Framework Element of the Los Angeles General Plan. Los Angeles, CA: City of Los Angeles.

Los Angeles Department of City Planning. (2005). ZA-2005-3672-ZAD-ZAA-SPR. Zoning Administrator Determination. Los Angeles, CA: City of Los Angeles.

Los Angeles Department of City Planning. (2012a). Hollywood Community Plan. Los Angeles, CA: City of Los Angeles. Retrieved 5 December 2014 from: http://cityplanning.lacity.org/complan/central/hwdpage.htm

Los Angeles Department of City Planning. (2012b). South Los Angeles Community Plan. Los Angeles, CA: City of Los Angeles. Retrieved 5 December 2014 from: http://cityplanning.lacity.org/ 
Los Angeles Department of City Planning. (2012c). Sylmar New Community Plan. Los Angeles, CA: City of Los Angeles. Retrieved 5 December 2014 from: http://planning.lacity.org/cpu/Sylmar/SylmarDraftPlan.htm

Los Angeles Department of City Planning. (2013). Draft West Adams-Baldwin HillsLeimert New Community Plan. Los Angeles, CA: City of Los Angeles. Retrieved 5 December 2014 from: https://sites.google.com/site/westadamsncp/home

Los Angeles Department of City Planning. (2014a). Southeast Los Angeles Community Plan. Los Angeles, CA: City of Los Angeles. Retrieved 5 December 2014 from: http://cityplanning.lacity.org/

Los Angeles Department of City Planning. (2014b). Boyle Heights New Community Plan Draft Goals and Policies. Los Angeles, CA: City of Los Angeles. Retrieved 5 December 2014 from: https://sites.google.com/site/boyleheightsncp/

Los Angeles Department of City Planning. (2014c). Draft San Pedro New Community Plan. Los Angeles, CA: City of Los Angeles. Retrieved 5 December 2014 from: https://sites.google.com/site/sanpedrocommunityplan/draft-plan-outline

Los Angeles Department of City Planning, D. (2014d). L.A Rising - how the Adaptive Reuse Ordinance Transformed Downtown Los Angeles. Unpublished document. Los Angeles, CA: City of Los Angeles

Los Angeles Department of City Planning. (2014e). Mobility Plan 2035. Los Angeles, CA: City of Los Angeles.

Los Angeles Department of City Planning. (2014f). [ARO Project List]. Unpublished Raw Data. Los Angeles, CA: City of Los Angeles 
Lucuik, M., Huffman, A., Trusty, W., \& Prefasi, A. (2010). The Greenest Building is the One that is Never Built: A Life-Cycle Assessment Study of Embodied Effects for Historic Buildings. Ottawa, Canada: ASHRAE.

Mayor's Office of Economic Development. (2004). Adaptive Reuse Program Sourcebook. Los Angeles, CA: City of Los Angeles.

Merlino, K. (2011). Report on Historic Preservation and Sustainability. Seattle, WA: University of Washington.

Merlino, K. (2014). [Re] Evaluating Significance: The Environmental and Cultural Value in Older and Historic Buildings. The Public Historian, 3(36), 70-85.

Moe, R. (2008). Sustainable Stewardship: Historic preservation's essential role in fighting climate change. Speech presented at the Berkeley Architectural Heritage Association, Berkeley California. Retrieved 9 October 2014 from: http://www.seattle.gov/council/attachments/codac/2008national_trust_hist.pdf

National Park Service. (n.d.). The Secretary of the Interior's Standards. Washington DC: U.S Department of the Interior. Retrieved May 21, 2015, from: http://www.nps.gov/tps/standards.htm

Office of Planning and Research (OPR) (2014). Changes to CEQA for Transit-oriented Development - FAQ. Sacramento, CA: Governor's Office of Planning and Research. Retrieved 5 February 2014 from: http://www.opr.ca.gov/s_transitorienteddevelopmentsb743.ph

Paulus, E. (2001). The Role of Historic Preservation in the Redevelopment of Urban Brownfields. Newark, DE: University of Delaware. 
Photographer Unknown. (n.d). Photograph of Barker Block Warehouse No.1. Retrieved 6 June 2015 from: http://www.belairinternet.com/barker-block-warehouse-no-1irreplaceable-character-in-las-art-district/'

Preservation Green Lab. (2011). The Greenest Building: Quantifying the Environmental Value of Building Reuse. Seattle, WA: National Trust for Historic Preservation.

Preservation Green Lab. (2014). Older, Smaller, Better: Measuring how the Character of Buildings and Blocks Influences Urban Vitality. Seattle, WA: National Trust for Historic Preservation.

Ryberg-Webster, S., \& Kinahan, K. (2013). Historic Preservation and Urban Revitalization in the Twenty-First Century. Journal Of Planning Literature, 2(29), 119-139.

SB 375. (2008). California State Legislature.

SCAG. (2012). 2012-2035 Regional Transportation Plan/Sustainable Communities Strategy (RTP/SCS): Towards a Sustainable Future. Retrieved 12 November 2014 from: http://rtpscs.scag.ca.gov/Pages/2012-2035-RTP-SCS.aspx

SCAG. (2012a). 2012-2035 Regional Transportation Plan/Sustainable Communities Strategy (RTP/SCS). Active Transportation Appendix. Retrieved 26 April 2015 from: http://rtpscs.scag.ca.gov/Pages/2012-2035-RTP-SCS.aspx

SCAG. (n.d). DRAFT SB 743 Transit Priority Areas (TPAs). Retrieved 5 February 2014 from: http://maps.scag.ca.gov/SB743/index.html

SCAG. (2014). About the SCS. Retrieved 6 October 2014 from: http://rtpscs.scag.ca.gov/Pages/About-the-SCS.aspx 
Schilling, J. (2002). The Revitalization of Vacant Properties. International City/County Management Association. Retrieved 21 December 2014 from: http://www.usmayors.org/brownfields/library/Revitalization_of_Vacant_Propertie s.pdf

Shigley, P. (2009). Downtown L.A.: The Rise, Fall and Plateau. California Planning \& Development Report, 24(3), March 2009. Retrieved 7 June 2015 from: http://www.cp-dr.com/node/2273

Shipley, R., Utz, S., \& Parsons, M. (2006). Does Adaptive Reuse Pay? A Study of the Business of Building Renovation in Ontario Canada. International Journal of Heritage Studies, 6(12), 505-520.

Sohmer, R., \& Lang, R. (1998). Beyond this Old House: Historic Preservation in Community Development. Housing Policy Debate, 3(9), 425-430.

Smith, O. (1920). Relief map of territory served by lines of [the] Pacific Electric Railway in Southern California; largest electric railway system in the world (Archival Image). Map collection on Los Angeles, California, the United States and the world (G4363 L8 1920). UCLA Library Special Collections, Los Angeles CA. Retrieved 6 June 2015 from: http://content.cdlib.org/ark:/13030/hb638nb72q/?layout=metadata

Stein, A. (2009). Greening Historic DC: Challenges and Opportunities to Incorporate Historic Preservation into the District's Drive for Sustainable Development. Washington DC: Georgetown University Law Center.

Sulaiman, S. (2015). Your Moment of City-Planning Zen: Lulu Guides you through the Community Plan Implementation Overlay Tool (Web blog post).Retrieved 3 May 
2015 from: http://la.streetsblog.org/2015/03/20/your-moment-of-city-planningzen-lulu-guides-you-through-the-community-plan-implementation-overlay-tool/ The Partnership for Building Reuse. (2013). Learning from Los Angeles. Washington DC: The National Trust for Historic Preservation.

The Partnership for Building Reuse. (2014). Building on Baltimore's History. Washington DC: The National Trust for Historic Preservation.

Tumlin, J., \& Millard-Ball, A. (2003). How to Make Transit-Oriented Development Work. Planning Magazine (May 2003).

U.S Census Bureau. (2013). 2013 American Community Survey, 5-Year Estimates, Profile of General Demographic Characteristics; Los Angeles, California. Generated by Author using Social Explorer.

U.S. Census Bureau. (2000). 2000 Census of Population and Housing, Profile of General Demographic Characteristics; Los Angeles, California. Generated by Los Angeles Department of City Planning / Demographic Research Unit, Retrieved 27 March 2015 from:http://planning.lacity.org/DR.

U.S. Energy Information Administration. (2003). Consumption of Gross Energy Intensity for Sum of Major Fuels for Non-Mall Buildings. Washington DC: Department of Energy. Retrieved 24 May 2014 from: http://www.eia.gov/consumption/commercial/data/archive/cbecs/cbecs2003/detail ed_tables_2003/2003set9/2003html/c3.html

Wildermuth, J. (2015). Mission District group wants temporary halt to new housing. San Francisco Chronicle. Retrieved 1 March 2015 from: 
http://www.sfgate.com/bayarea/article/Mission-District-group-wants-temporaryhalt-to-6086183.php

Young, M. (2009). Adapting to Adaptive Reuse: Comments and Concerns about the Impacts of a Growing Phenomenon. Southern California Interdisciplinary Law Journal, 18 (703), 703-730

Yung, E., \& Chan, E. (2012). Implementation Challenges to the Adaptive Reuse of Heritage Buildings: Towards the Goals of Sustainable, Low Carbon Cities. Habitat International, 3(36), 352-361. 


\section{APPENDICES}

\section{Appendix A: Spatial Analysis, Buffer Analysis Around Metro Stations}

Table 9: Metro Buffer Analysis, New Buildings

\begin{tabular}{|c|c|c|c|c|c|}
\hline \multirow{2}{*}{\begin{tabular}{c}
\multirow{2}{*}{$\begin{array}{c}\text { Development } \\
\text { Characteristics }\end{array}$} \\
\cline { 4 - 6 }
\end{tabular}} & \multirow{2}{*}{ Total } & \multicolumn{2}{|c|}{$\begin{array}{c}\text { Buildings Constructed in } \\
\text { Half Mile of Metro Station }\end{array}$} & $\begin{array}{c}\text { Buildings Constructed not } \\
\text { within Half Mile of Metro } \\
\text { Station }\end{array}$ \\
\cline { 5 - 6 } & Number & $\%$ of Total & Number & \% of Total \\
\hline Citywide & 26,144 & 1,486 & $6 \%$ & 24,658 & $94 \%$ \\
\hline $\begin{array}{c}\text { Single Family } \\
\text { Dwelling }\end{array}$ & 19,931 & 506 & $3 \%$ & 19,425 & $97 \%$ \\
\hline $\begin{array}{c}\text { Multi-Family } \\
\text { Dwelling }\end{array}$ & 3,972 & 620 & $16 \%$ & 3,352 & $84 \%$ \\
\hline Commercial & 1,329 & 218 & $16 \%$ & 1,111 & $84 \%$ \\
\hline Other ${ }^{1}$ & 912 & 142 & $16 \%$ & 770 & $84 \%$ \\
\hline
\end{tabular}

Note. Building age data has been obtained from the 2014 Los Angeles County Assessor data for 2014.

1. "Other" includes industrial, institutional, recreational, and miscellaneous buildings. 
Table 10: Metro Buffer Analysis, ARO Projects

\begin{tabular}{|c|c|c|c|c|c|}
\hline \multirow{2}{*}{ Project Characteristics } & \multirow[b]{2}{*}{ Total } & \multicolumn{2}{|c|}{$\begin{array}{l}\text { ARO Projects in Half Mile } \\
\text { of Metro Station }\end{array}$} & \multicolumn{2}{|c|}{$\begin{array}{l}\text { ARO Projects not within Half } \\
\text { Mile of Metro Station }\end{array}$} \\
\hline & & Number & $\begin{array}{l}\% \text { of Total } \\
\text { Project }\end{array}$ & Number & $\begin{array}{l}\% \text { of Total } \\
\text { Projects }\end{array}$ \\
\hline Citywide & 153 & 110 & $72 \%$ & 43 & $28 \%$ \\
\hline $\begin{array}{c}\text { Number of Dwelling } \\
\text { Units }^{1}\end{array}$ & 13,358 & 10,716 & $80 \%$ & 2,642 & $20 \%$ \\
\hline $\begin{array}{l}\text { Commercial } \\
\text { Condominiums }\end{array}$ & 689 & 670 & $97 \%$ & 19 & $3 \%$ \\
\hline $\begin{array}{l}\text { Square Footage of } \\
\text { Commercial Space }\end{array}$ & 164,853 & 92,853 & $56 \%$ & 72,000 & $44 \%$ \\
\hline Conversion Date Range ${ }^{2}$ & $\begin{array}{l}1999- \\
2014\end{array}$ & $2000-2014$ & & $1999-2013$ & \\
\hline
\end{tabular}

1. The number of dwelling units, commercial condominiums and square footage of commercial space are approximations made through numbers provided by vesting tentative tract maps, zoning administrator determinations, and building permits. These different forms often had conflicting numbers of units, commercial spaces, and parking spaces.

2. Conversion date ranges from the date of the zoning administrator's approval to the date when the permit was issued. 
Table 11: Metro Buffer Analysis, Community Plan Areas

\begin{tabular}{|c|c|}
\hline \multicolumn{2}{|c|}{$\begin{array}{c}\text { Central City (1/2 Mile from Pershing Square, Civic Center, Little Tokyo/Arts District, } \\
\text { Metro Center, Pico, Grand Metro Stations) }\end{array}$} \\
\hline Number of ARO Projects & 81 \\
\hline Number of Dwelling Units & 8,928 \\
\hline $\begin{array}{l}\text { Square Footage of } \\
\text { Commercial Space }\end{array}$ & 55,352 square feet of commercial/retail space \\
\hline $\begin{array}{l}\text { Number of Commercial } \\
\text { Condominiums }\end{array}$ & 643 \\
\hline Conversion Date Range & $1999-2014$ \\
\hline \multicolumn{2}{|c|}{ Hollywood (1/2 Mile from Hollywood/Highland, Hollywood/Vine Metro Stations) } \\
\hline Number of ARO Projects & 10 \\
\hline Number of Dwelling Units & 506 \\
\hline $\begin{array}{l}\text { Square Footage of } \\
\text { Commercial Space }\end{array}$ & 10,000 square feet of commercial/retail space \\
\hline $\begin{array}{l}\text { Number of Commercial } \\
\text { Condominiums }\end{array}$ & 21 \\
\hline Conversion Date Range & $2003-2014$ \\
\hline \multicolumn{2}{|c|}{ North Hollywood (1/2 Mile from North Hollywood Metro Station) } \\
\hline Number of ARO Projects & 1 \\
\hline Number of Dwelling Units & 5 \\
\hline $\begin{array}{l}\text { Square Footage of } \\
\text { Commercial Space }\end{array}$ & 0 \\
\hline $\begin{array}{l}\text { Number of Commercial } \\
\text { Condominiums }\end{array}$ & 0 \\
\hline Conversion Date & Date not available \\
\hline \multicolumn{2}{|c|}{ Northeast (1/2 Mile from Lincoln Heights/Cypress Park Station) } \\
\hline Number of ARO Projects & 3 \\
\hline Number of Dwelling Units & 138 \\
\hline $\begin{array}{l}\text { Square Footage of } \\
\text { Commercial Space }\end{array}$ & Data not available \\
\hline $\begin{array}{l}\text { Number of Commercial } \\
\text { Condominiums }\end{array}$ & 6 \\
\hline Conversion Date & $2003-2006$ \\
\hline \multicolumn{2}{|c|}{$\begin{array}{l}\text { Wilshire (1/2 Mile from Wilshire / Western \& Wilshire / Normandie \& Wilshire / Vermon } \\
\text { Metro Stations) }\end{array}$} \\
\hline Number of ARO Projects & 4 \\
\hline Number of Dwelling Units & 388 \\
\hline $\begin{array}{l}\text { Square Footage of } \\
\text { Commercial Space }\end{array}$ & 27,500 square feet \\
\hline $\begin{array}{l}\text { Number of Commercial } \\
\text { Condominiums }\end{array}$ & Data not available \\
\hline Conversion Date & 2005-2006 \\
\hline
\end{tabular}




\begin{tabular}{|c|c|}
\hline \multicolumn{2}{|c|}{ Westlake (1/2 Mile from Metro Center Metro Station) } \\
\hline Number of ARO Projects & 2 \\
\hline Number of Dwelling Units & 455 \\
\hline $\begin{array}{l}\text { Square Footage of } \\
\text { Commercial Space }\end{array}$ & Data not available \\
\hline $\begin{array}{l}\text { Number of Commercial } \\
\text { Condominiums }\end{array}$ & Data not available \\
\hline Conversion Date & $2005-2007$ \\
\hline \multicolumn{2}{|c|}{$\begin{array}{c}\text { Central City North (1/2 Mile from Chinatown, Union, Little Tokyo/Arts District, Pico/Aliso } \\
\text { Metro Stations) }\end{array}$} \\
\hline Number of ARO Projects & 7 \\
\hline Number of Dwelling Units & 195 \\
\hline $\begin{array}{l}\text { Square Footage of } \\
\text { Commercial Space }\end{array}$ & Data not available \\
\hline $\begin{array}{l}\text { Number of Commercial } \\
\text { Condominiums }\end{array}$ & Data not available \\
\hline Conversion Date & $2004-2012$ \\
\hline
\end{tabular}

Table 12: ARO Projects Compared to Buildings Constructed Between 1999 and 2013, Central City Area

\begin{tabular}{|c|c|c|c|c|c|}
\hline \multirow{2}{*}{ Development Category } & \multirow{2}{*}{ Total } & \multicolumn{2}{|c|}{ Half Mile of Metro Station } & \multicolumn{2}{c|}{$\begin{array}{c}\text { Not within Half Mile of Metro } \\
\text { Station }\end{array}$} \\
\cline { 3 - 6 } & Number & $\begin{array}{c}\text { \% of Total } \\
\text { Projects/Buildings }\end{array}$ & Number & $\begin{array}{c}\text { \% of Tolal } \\
\text { Projects/Buildings }\end{array}$ \\
\hline Buildings 1999-2013 & 128 & 74 & $6 \%$ & 54 & $94 \%$ \\
\hline ARO Projects & 86 & 80 & $93 \%$ & 6 & $7 \%$ \\
\hline $\begin{array}{c}\text { Ratio of New Buildings } \\
\text { to ARO Projects }\end{array}$ & $1.5: 1$ & $1: 1$ & & $9: 1$ & \\
\hline
\end{tabular}


Figure 17: Spatial Distribution of ARO Projects

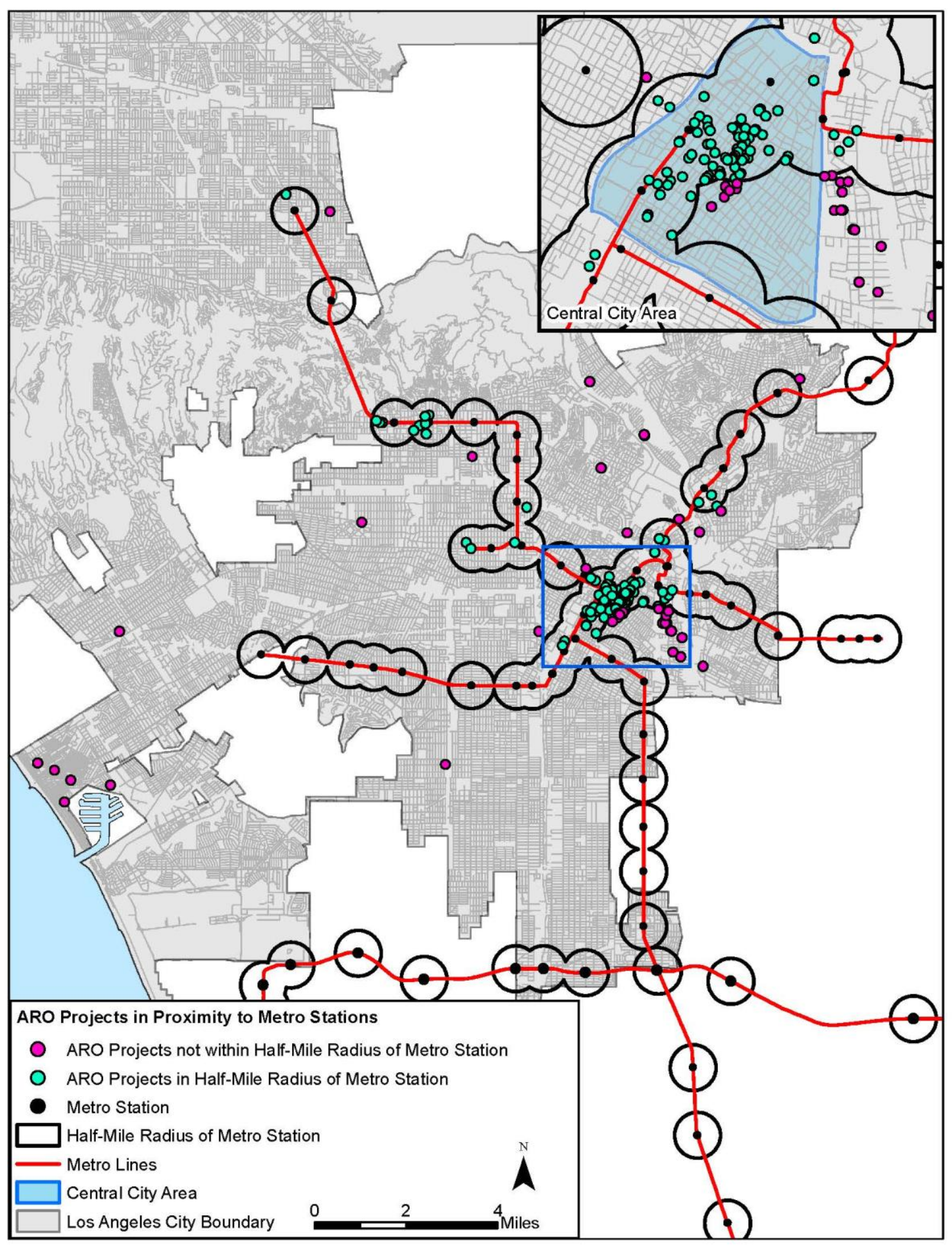


Figure 18: Spatial Distribution of ARO Projects (ARO Incentive Areas)

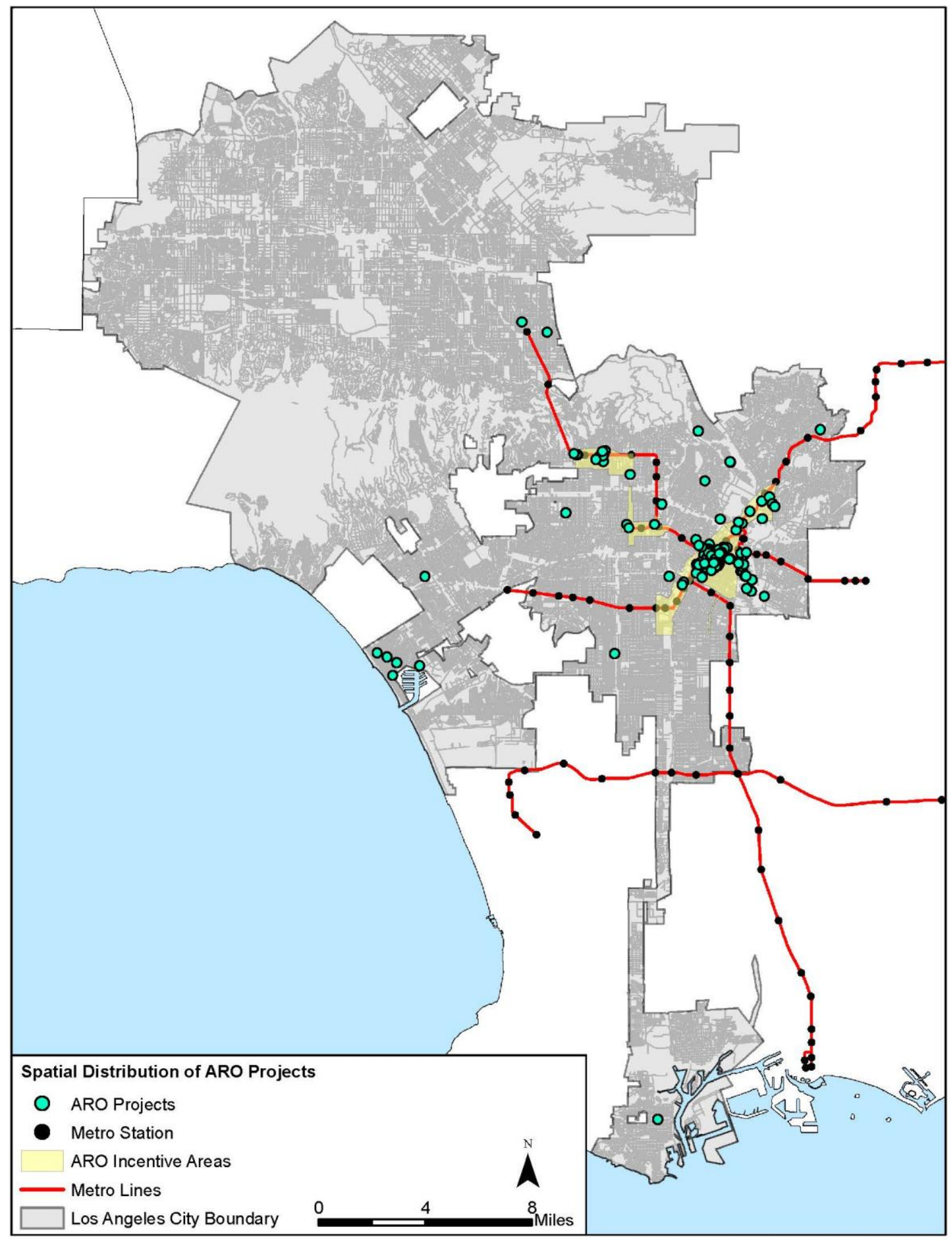


Figure 19: Spatial Distribution of ARO Projects (Community Plan Areas)

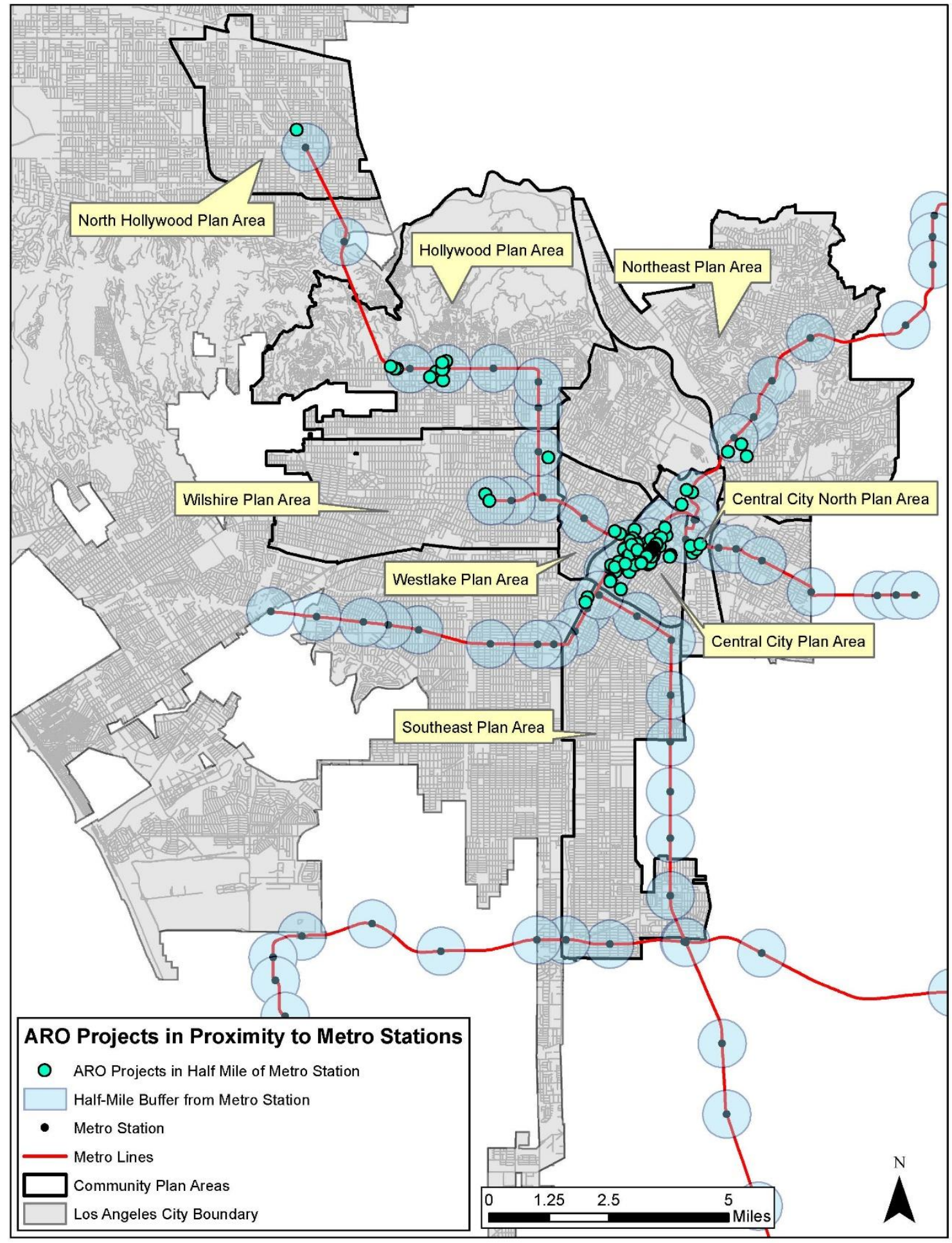




\section{Appendix B: Buffer Analysis Around Metro Stations (Permit Data)}

Table 13: Metro Buffer Analysis, Building Permits (January 2013 - January 2015)

\begin{tabular}{|c|c|c|c|c|c|}
\hline \multirow{2}{*}{$\begin{array}{l}\text { Development } \\
\text { Characteristics }\end{array}$} & \multirow[b]{2}{*}{ Total } & \multicolumn{2}{|c|}{$\begin{array}{c}\text { New Development } \\
\text { Permitted in Half Mile of } \\
\text { Metro Station }\end{array}$} & \multicolumn{2}{|c|}{$\begin{array}{l}\text { New Development Permitted } \\
\text { Not Within Half Mile of Metro } \\
\text { Station }\end{array}$} \\
\hline & & Number & $\begin{array}{l}\% \text { of Total } \\
\text { Permits }\end{array}$ & Number & $\begin{array}{l}\% \text { of Total } \\
\text { Permits }\end{array}$ \\
\hline Citywide & 5,778 & 279 & $5.26 \%$ & 5,509 & $94.73 \%$ \\
\hline $\begin{array}{c}1 \text { or } 2 \text { Family } \\
\text { Dwelling }\end{array}$ & 4,755 & 159 & $4.83 \%$ & 4,596 & $95.34 \%$ \\
\hline Apartment & 439 & 36 & $2.75 \%$ & 403 & $79.54 \%$ \\
\hline Commercial & 594 & 84 & $0.62 \%$ & 510 & $6.97 \%$ \\
\hline Central City & 35 & 27 & $1.45 \%$ & 8 & $8.83 \%$ \\
\hline Central City North & 22 & 5 & $0.00 \%$ & 17 & $0.00 \%$ \\
\hline Hollywood & 297 & 33 & $0.47 \%$ & 264 & $0.14 \%$ \\
\hline North Hollywood & 135 & 3 & $0.09 \%$ & 132 & $0.29 \%$ \\
\hline Northeast & 184 & 9 & $0.57 \%$ & 175 & $4.57 \%$ \\
\hline Wilshire & 312 & 22 & $0.05 \%$ & 290 & $2.28 \%$ \\
\hline Westlake & 15 & 5 & $0.16 \%$ & 10 & $3.03 \%$ \\
\hline Southeast & 431 & 99 & $0.38 \%$ & 332 & $5.02 \%$ \\
\hline
\end{tabular}

Note. New construction permit data has been obtained from the DataLA, the open data portal for the City of Los Angeles (https://data.lacity.org/). This dataset only includes building permits from January 2013 to January 2015. Earlier permit data is available from 2001 to 2014 through Plan Check and Inspection Disks, inspection from the Department of Building and Safety (DBS). These disks only include monthly permit data, they cost $\$ 11$ each and they must be purchased in person from the DBS office in Los Angeles. Earlier permit data (prior to 2001) must be viewed on microfilm at the DBS office. 
Figure 20: ARO Projects and New Development Permits

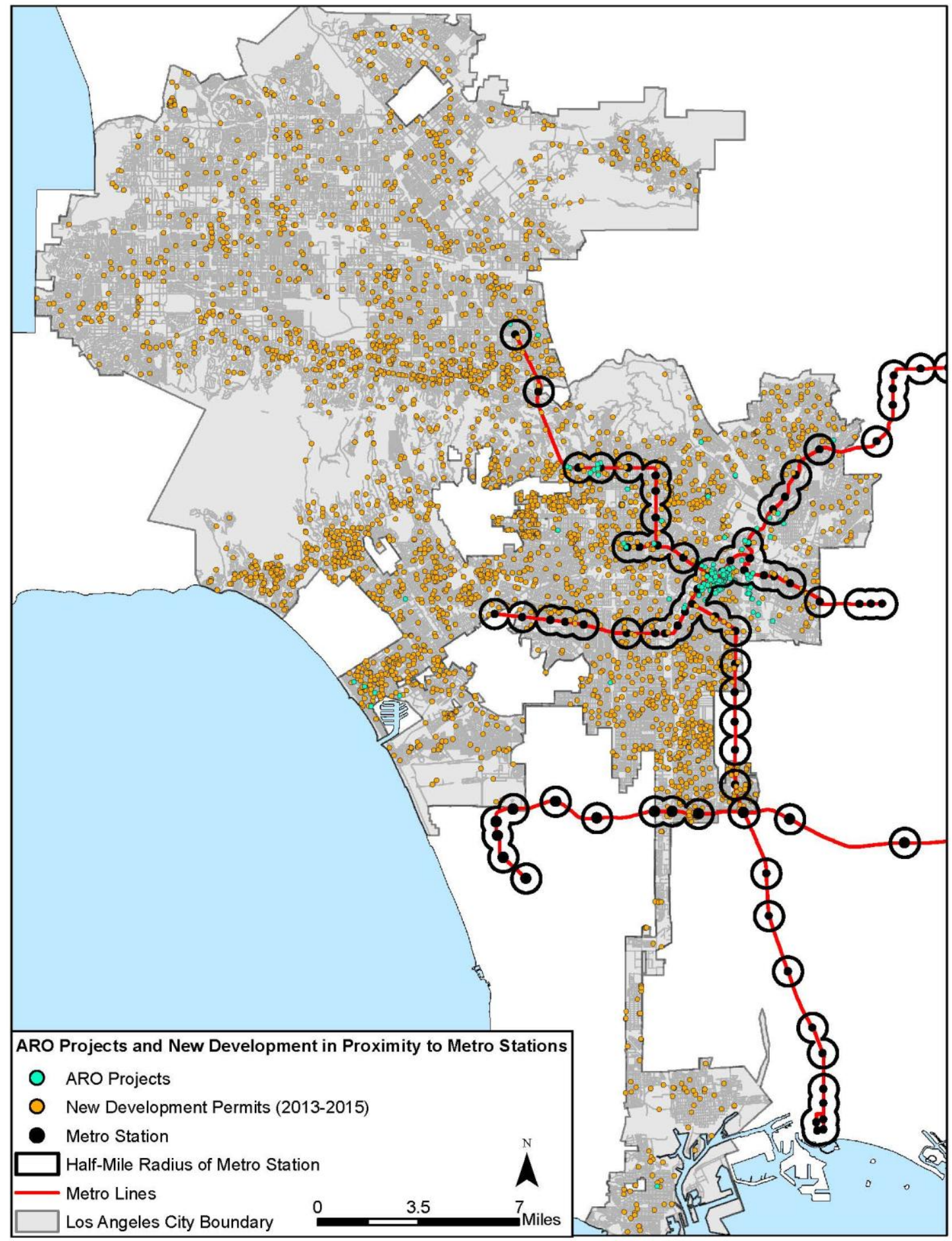


Figure 21: New Development Permits in Proximity to Transit

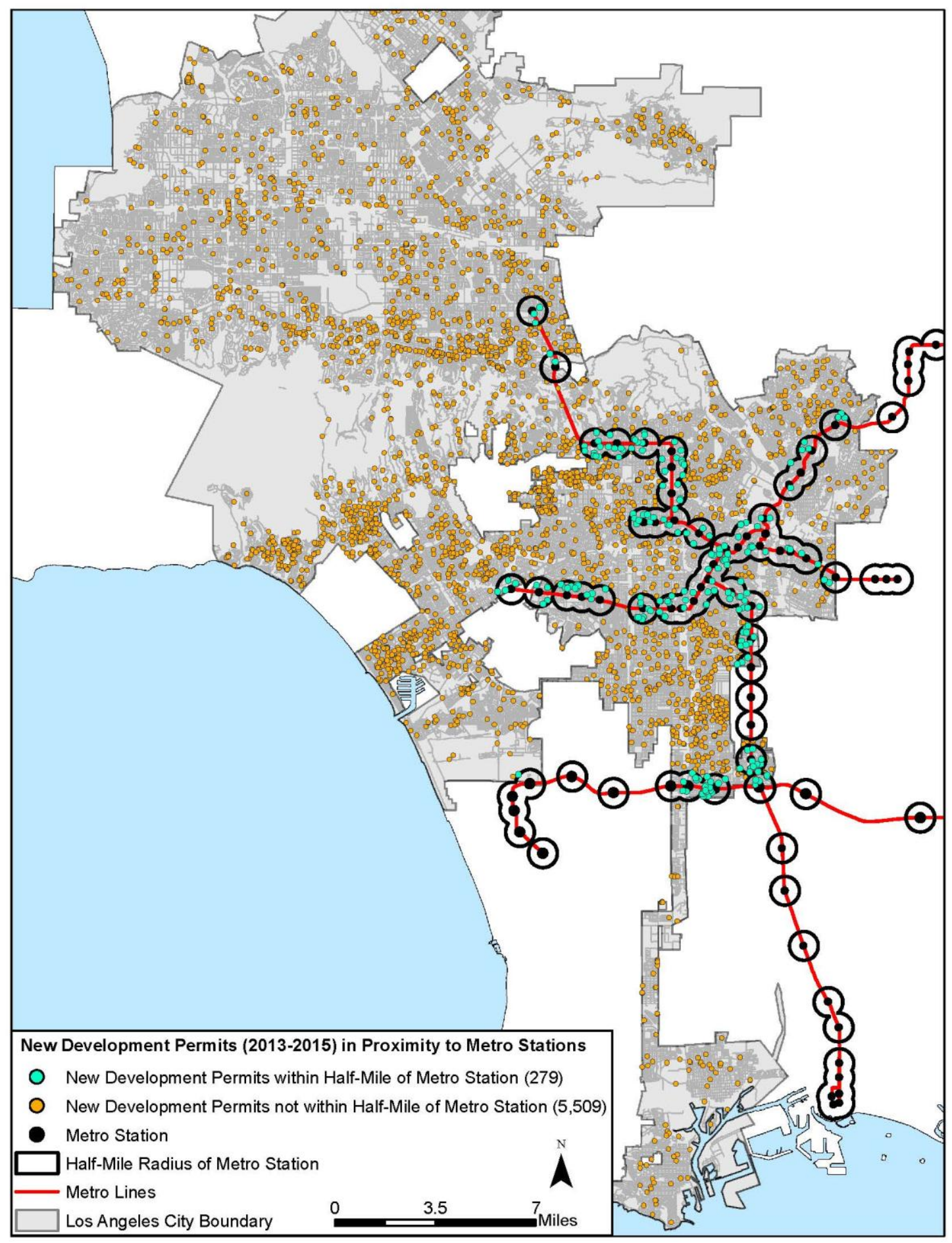


Table 14: ARO Projects compared to New Development Permits

\begin{tabular}{|c|c|c|c|c|c|}
\hline \multirow{2}{*}{ Development Category } & \multirow{2}{*}{ Total } & \multicolumn{2}{|c|}{ Half Mile of Metro Station } & \multicolumn{2}{c|}{$\begin{array}{c}\text { Not within Half Mile of Metro } \\
\text { Station }\end{array}$} \\
\cline { 3 - 6 } & Number & $\begin{array}{c}\text { \% of Total } \\
\text { Projects/Permits }\end{array}$ & Number & $\begin{array}{c}\text { \% of Total } \\
\text { Projects/Permits }\end{array}$ \\
\hline $\begin{array}{c}\text { New Development } \\
\text { Permits }\end{array}$ & 5,778 & 279 & $5 \%$ & 5,509 & $95 \%$ \\
\hline ARO Projects & 153 & 110 & $72 \%$ & 43 & $28 \%$ \\
\hline $\begin{array}{c}\text { Ratio of New } \\
\text { Development Permits } \\
\text { to ARO Projects }\end{array}$ & $38: 1$ & $3: 1$ & & $128: 1$ & \\
\hline
\end{tabular}

\section{Appendix C: ARO Projects in High Quality Transit Areas (HQTA) and Transit}

\section{Priority Areas (TPA)}

Table 15: ARO Projects in HQTAs and TPAs

\begin{tabular}{|c|c|c|c|c|c|c|c|}
\hline \multirow{2}{*}{$\begin{array}{c}\text { Project } \\
\text { Characteristics }\end{array}$} & \multirow{2}{*}{ Total } & \multicolumn{2}{|c|}{$\begin{array}{c}\text { ARO Projects Inside SCAG } \\
\text { Transit Priority Areas \& } \\
\text { HQTAs }\end{array}$} & \multicolumn{2}{|c|}{$\begin{array}{l}\text { ARO Projects Only Inside } \\
\text { SCAG HQTAs }\end{array}$} & \multicolumn{2}{|c|}{$\begin{array}{l}\text { ARO Projects Outside } \\
\text { SCAG Transit Priority } \\
\text { Areas \& HQTAs }\end{array}$} \\
\hline & & Number & $\begin{array}{l}\% \text { of Total } \\
\text { Projects }\end{array}$ & Number & $\begin{array}{l}\% \text { of Total } \\
\text { Projects }\end{array}$ & Number & $\begin{array}{l}\% \text { of Total } \\
\text { Projects }\end{array}$ \\
\hline Citywide & 153 & 145 & $95 \%$ & 7 & $5 \%$ & 1 & $1 \%$ \\
\hline $\begin{array}{c}\text { Number of } \\
\text { Dwelling Units }\end{array}$ & 13,358 & 13,145 & $98 \%$ & 213 & $2 \%$ & $\begin{array}{l}\text { Data Not } \\
\text { Available }\end{array}$ & $\begin{array}{l}\text { Data Not } \\
\text { Available }\end{array}$ \\
\hline $\begin{array}{l}\text { Commercial } \\
\text { Condominiums }\end{array}$ & 689 & 689 & $100 \%$ & $\begin{array}{l}\text { Data Not } \\
\text { Available }\end{array}$ & $\begin{array}{l}\text { Data Not } \\
\text { Available }\end{array}$ & $\begin{array}{l}\text { Data Not } \\
\text { Available }\end{array}$ & $\begin{array}{l}\text { Data Not } \\
\text { Available }\end{array}$ \\
\hline $\begin{array}{c}\text { Square Footage } \\
\text { of Commercial } \\
\text { Space } \\
\end{array}$ & 164,853 & 164,853 & $100 \%$ & $\begin{array}{l}\text { Data Not } \\
\text { Available }\end{array}$ & $0 \%$ & $\begin{array}{l}\text { Data Not } \\
\text { Available }\end{array}$ & $\begin{array}{l}\text { Data Not } \\
\text { Available }\end{array}$ \\
\hline $\begin{array}{c}\text { Conversion } \\
\text { Date Range }^{2}\end{array}$ & $\begin{array}{l}1999- \\
2014\end{array}$ & 1999-2014 & & 2003-2007 & & $2005-2006$ & \\
\hline
\end{tabular}

1. The number of dwelling units, commercial condominiums and square footage of commercial space are approximations made through numbers provided by vesting tentative tract maps, zoning administrator determinations, and building permits. These different forms often had conflicting numbers of units, commercial spaces, and parking spaces.

2. Conversion date ranges from the date of the zoning administrator's approval to the date when the permit was issued. 
Table 16: New Development Permits (2013 - 2015) in HQTAs and TPAs

\begin{tabular}{|c|c|c|c|c|c|}
\hline \multirow{2}{*}{$\begin{array}{l}\text { Development } \\
\text { Characteristics }\end{array}$} & \multirow[b]{2}{*}{ Total } & \multicolumn{2}{|c|}{$\begin{array}{c}\text { New Development } \\
\text { Permitted Inside SCAG } \\
\text { HQTAs }\end{array}$} & \multicolumn{2}{|c|}{$\begin{array}{c}\text { New Development } \\
\text { Permitted Outside SCAG } \\
\text { HQTAs }\end{array}$} \\
\hline & & Number & $\begin{array}{c}\% \text { of Total } \\
\text { Permits }\end{array}$ & Number & $\begin{array}{l}\% \text { of Total } \\
\text { Permits }\end{array}$ \\
\hline Citywide & 5,778 & 4,922 & $85 \%$ & 866 & $15 \%$ \\
\hline $\begin{array}{c}1 \text { or } 2 \text { Family } \\
\text { Dwelling }\end{array}$ & 4,755 & 4,004 & $84 \%$ & 751 & $19 \%$ \\
\hline Apartment & 439 & 411 & $94 \%$ & 28 & $7 \%$ \\
\hline Commercial & 594 & 507 & $85 \%$ & 87 & $17 \%$ \\
\hline
\end{tabular}

Note. New construction permit data has been obtained from the DataLA, the open data portal for the City of Los Angeles (https://data.lacity.org/). This dataset only includes building permits from January 2013 to January 2015. Earlier permit data is available from 2001 to 2014 through Plan Check and Inspection Disks, inspection from the Department of Building and Safety (DBS). These disks only include monthly permit data, they cost $\$ 11$ each and they must be purchased in person from the DBS office in Los Angeles. Earlier permit data (prior to 2001) must be viewed on microfilm at the DBS office.

Table 17: HQTAs - ARO Projects compared to New Development Permits

\begin{tabular}{|c|c|c|c|c|c|}
\hline \multirow{2}{*}{$\begin{array}{l}\text { Development } \\
\text { Category }\end{array}$} & \multirow[b]{2}{*}{ Total } & \multicolumn{2}{|c|}{ Inside SCAG HQTAs } & \multicolumn{2}{|c|}{ Outside SCAG HQTAs } \\
\hline & & $\begin{array}{c}\text { Numbe } \\
\mathrm{r}\end{array}$ & $\begin{array}{c}\% \text { of Total } \\
\text { Projects/Permi } \\
\text { ts }\end{array}$ & $\begin{array}{c}\text { Numbe } \\
\mathrm{r}\end{array}$ & $\begin{array}{c}\% \text { of Total of } \\
\text { Projects/Permits }\end{array}$ \\
\hline $\begin{array}{l}\text { New Development } \\
\text { Permits }\end{array}$ & 5,778 & 4,922 & $85 \%$ & 866 & $15 \%$ \\
\hline ARO Projects & 153 & 152 & $72 \%$ & 1 & $.01 \%$ \\
\hline $\begin{array}{c}\text { Ratio of New } \\
\text { Development Permits } \\
\text { to ARO Projects }\end{array}$ & $38: 1$ & $32: 1$ & & $866: 1$ & \\
\hline
\end{tabular}


Figure 22: ARO Projects in HQTAs and TPAs

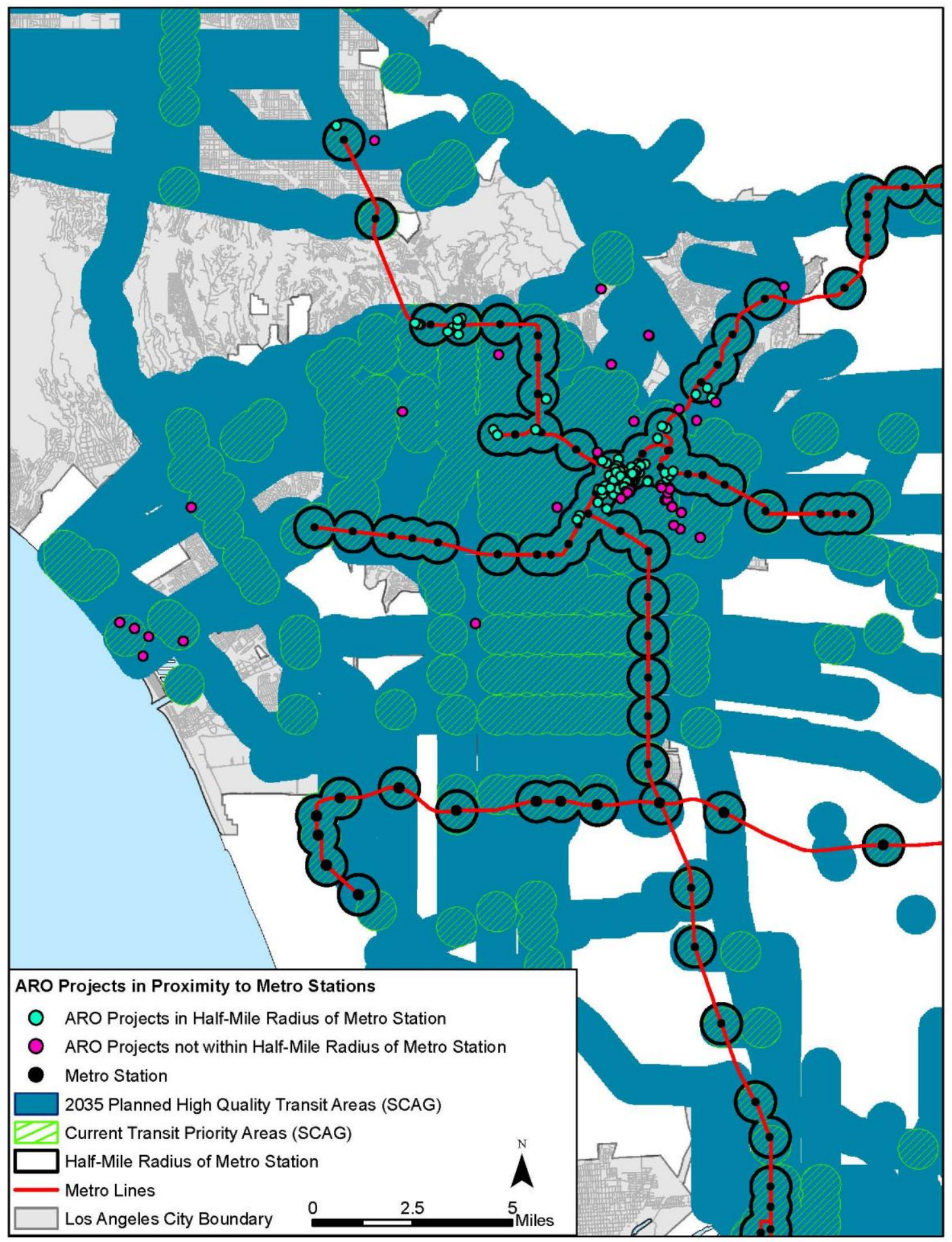




\section{Appendix D: ARO Projects Located in Higher-Intensity Land Use Districts}

Table 18: ARO Projects Regional Inside Regional Land Use Centers

\begin{tabular}{|c|c|c|c|c|c|}
\hline \multirow{2}{*}{ Project Characteristics } & \multirow[b]{2}{*}{ Total } & \multicolumn{2}{|c|}{$\begin{array}{l}\text { ARO Projects inside } \\
\text { Selected Region Land } \\
\text { Use Centers }\end{array}$} & \multicolumn{2}{|c|}{$\begin{array}{l}\text { ARO Projects not inside } \\
\text { Selected Regional Land } \\
\text { Use Centers }\end{array}$} \\
\hline & & Number & $\begin{array}{l}\% \text { of Total } \\
\text { Projects }\end{array}$ & Number & $\begin{array}{l}\% \text { of Total } \\
\text { Projects }\end{array}$ \\
\hline Citywide & 153 & 72 & $47 \%$ & 43 & $53 \%$ \\
\hline $\begin{array}{c}\text { Number of Dwelling } \\
\text { Units }^{1}\end{array}$ & 13,296 & 7,635 & $57 \%$ & 5,661 & $43 \%$ \\
\hline $\begin{array}{c}\text { Commercial } \\
\text { Condominiums or } \\
\text { Units }\end{array}$ & 689 & 644 & $93 \%$ & 45 & $7 \%$ \\
\hline $\begin{array}{l}\text { Square Footage of } \\
\text { Commercial Space }\end{array}$ & 164,853 & 91,646 & $56 \%$ & 73,207 & $44 \%$ \\
\hline $\begin{array}{c}\text { Conversion Date } \\
\text { Range }^{2}\end{array}$ & $\begin{array}{l}1999- \\
2014\end{array}$ & 1999-2014 & & 1999-2014 & \\
\hline
\end{tabular}

1. The number of dwelling units, commercial condominiums and square footage of commercial space are approximations made through numbers provided by vesting tentative tract maps, zoning administrator determinations, and building permits. These different forms often had conflicting numbers of units, commercial spaces, and parking spaces.

2. Conversion date ranges from the date of the zoning administrator's approval to the date when the permit was issued.

Table 19: Development Permits (2013-2015) Inside Regional Land Use Centers

\begin{tabular}{|c|c|c|c|c|c|}
\hline \multirow{2}{*}{$\begin{array}{c}\text { Development } \\
\text { Characteristics }\end{array}$} & \multirow{2}{*}{ Total } & \multicolumn{2}{|c|}{$\begin{array}{c}\text { New Development } \\
\text { Pegmitted Inside Selected } \\
\text { Regional Land Use } \\
\text { Centers }\end{array}$} & \multicolumn{2}{|c|}{$\begin{array}{c}\text { New Development Permitted } \\
\text { Outside Selected Regional } \\
\text { Land Use Centers }\end{array}$} \\
\cline { 3 - 6 } & & $\begin{array}{c}\text { Number } \\
\text { Permits }\end{array}$ & Number & $\begin{array}{c}\% \text { of Total } \\
\text { Permits }\end{array}$ \\
\hline Citywide & 5,778 & 33 & $1 \%$ & 5,745 & $99 \%$ \\
\hline $\begin{array}{c}\text { 1 or 2 Family } \\
\text { Dwelling }\end{array}$ & 4,755 & 0 & $0 \%$ & 4,755 & $100 \%$ \\
\hline Apartment & 439 & 14 & $3 \%$ & 425 & $97 \%$ \\
\hline Commercial & 594 & 19 & $3 \%$ & 575 & $97 \%$ \\
\hline
\end{tabular}

Note. New construction permit data has been obtained from the DataLA, the open data portal for the City of Los Angeles (https://data.lacity.org/). This dataset only includes building permits from January 2013 to January 2015. Earlier permit data is available from 2001 to 2014 through Plan Check and Inspection Disks, inspection from the Department of Building and Safety (DBS). These disks only include monthly permit data, they cost $\$ 11$ each and they must be purchased in person from the DBS office in Los Angeles. Earlier permit data (prior to 2001) must be viewed on microfilm at the DBS office. 
Table 20: ARO Projects and New Development Permits, Regional Land Use Centers

\begin{tabular}{|c|c|c|c|c|c|}
\hline \multirow{2}{*}{$\begin{array}{c}\text { Development } \\
\text { Category }\end{array}$} & Total & $\begin{array}{c}\text { Inside Selected Regional } \\
\text { Land Use Centers }\end{array}$ & \multicolumn{2}{|c|}{$\begin{array}{c}\text { Outside Selected Regional } \\
\text { Land Use Centers }\end{array}$} \\
\cline { 3 - 6 } & Numbe & $\begin{array}{c}\text { \% of Total } \\
\text { Projects/Permi } \\
\text { ts }\end{array}$ & $\begin{array}{c}\text { Numbe } \\
\text { r }\end{array}$ & $\begin{array}{c}\text { \% of Total of } \\
\text { Projects/Permits }\end{array}$ \\
\hline $\begin{array}{c}\text { New Development } \\
\text { Permits }\end{array}$ & 5,778 & 33 & $1 \%$ & 5,745 & $99 \%$ \\
\hline ARO Projects & 153 & 72 & $47 \%$ & 43 & $53 \%$ \\
\hline $\begin{array}{c}\text { Ratio of New } \\
\text { Development Permits } \\
\text { to ARO Projects }\end{array}$ & $38: 1$ & $.46: 1$ & & $134: 1$ & \\
\hline
\end{tabular}

Table 21: ARO Projects Inside Community Land Use Centers

\begin{tabular}{|c|c|c|c|c|c|}
\hline \multirow{2}{*}{ Project Characteristics } & \multirow{2}{*}{ Total } & \multicolumn{2}{|c|}{$\begin{array}{c}\text { ARO Projects Inside } \\
\text { Selected Community } \\
\text { Land Use Centers }\end{array}$} & \multicolumn{2}{|c|}{$\begin{array}{c}\text { ARO Projects Not Inside } \\
\text { Selected Community } \\
\text { Land Use Centers }\end{array}$} \\
\cline { 4 - 6 } & & Number & $\begin{array}{c}\text { \% of Total } \\
\text { Projects }\end{array}$ & Number & $\begin{array}{c}\text { \% of Total } \\
\text { Projects }\end{array}$ \\
\hline Citywide & 153 & 12 & $8 \%$ & 141 & $92 \%$ \\
\hline $\begin{array}{c}\text { Number of Dwelling } \\
\text { Units }\end{array}$ & 13,296 & 1,233 & $9 \%$ & 12,063 & $91 \%$ \\
\hline $\begin{array}{c}\text { Commercial } \\
\text { Condominiums or } \\
\text { Units }\end{array}$ & 689 & 12 & $2 \%$ & 677 & $98 \%$ \\
\hline $\begin{array}{c}\text { Square Footage of } \\
\text { Commercial Space }\end{array}$ & 164,853 & $\begin{array}{c}\text { Data Not } \\
\text { Available }\end{array}$ & $0 \%$ & 164,853 & $100 \%$ \\
\hline $\begin{array}{c}\text { Conversion Date } \\
\text { Range }\end{array}$ & $1999-$ & $2000-2007$ & & $1999-2014$ & \\
\hline
\end{tabular}

1. The number of dwelling units, commercial condominiums and square footage of commercial space are approximations made through numbers provided by vesting tentative tract maps, zoning administrator determinations, and building permits. These different forms often had conflicting numbers of units, commercial spaces, and parking spaces.

2. Conversion date ranges from the date of the zoning administrator's approval to the date when the permit was issued. 
Table 22: Development Permits (2013-2015) Inside Community Land Use Centers

\begin{tabular}{|c|c|c|c|c|c|}
\hline \multirow{2}{*}{$\begin{array}{c}\text { Development } \\
\text { Characteristics }\end{array}$} & \multirow{2}{*}{ Total } & \multicolumn{2}{|c|}{$\begin{array}{c}\text { New Development } \\
\text { Permitted Inside Selected } \\
\text { Community Land Use } \\
\text { Centers }\end{array}$} & $\begin{array}{c}\text { New Development Permitted } \\
\text { Outside Selected } \\
\text { Community Land Use } \\
\text { Centers }\end{array}$ \\
\cline { 3 - 6 } & & Number & $\begin{array}{c}\text { \% ormits } \\
\text { Pertal }\end{array}$ & Number & $\begin{array}{c}\text { Notal } \\
\text { Permits }\end{array}$ \\
\hline Citywide & 5,778 & 17 & $.3 \%$ & 5,761 & $99.7 \%$ \\
\hline $\begin{array}{c}1 \text { or 2 Family } \\
\text { Dwelling }\end{array}$ & 4,755 & 5 & $.1 \%$ & 4,750 & $99.9 \%$ \\
\hline Apartment & 439 & 3 & $.7 \%$ & 425 & $99.3 \%$ \\
\hline Commercial & 594 & 9 & $1.5 \%$ & 575 & $98.5 \%$ \\
\hline
\end{tabular}

Note. New construction permit data has been obtained from the DataLA, the open data portal for the City of Los Angeles (https://data.lacity.org/). This dataset only includes building permits from January 2013 to January 2015. Earlier permit data is available from 2001 to 2014 through Plan Check and Inspection Disks, inspection from the Department of Building and Safety (DBS). These disks only include monthly permit data, they cost $\$ 11$ each and they must be purchased in person from the DBS office in Los Angeles. Earlier permit data (prior to 2001) must be viewed on microfilm at the DBS office.

Table 23: ARO Projects and Development Permits, Community Land Use Centers

\begin{tabular}{|c|c|c|c|c|c|}
\hline \multirow{2}{*}{\begin{tabular}{c}
\multirow{2}{*}{$\begin{array}{c}\text { Development } \\
\text { Category }\end{array}$} \\
\cline { 3 - 6 }
\end{tabular}} & \multirow{2}{*}{ Total } & \multicolumn{2}{|}{$\begin{array}{r}\text { Inside Community Land } \\
\text { Use Centers }\end{array}$} & \multicolumn{2}{|c|}{$\begin{array}{c}\text { Outside Community Land } \\
\text { Use Centers }\end{array}$} \\
\cline { 3 - 6 } & Number & $\begin{array}{r}\text { \% of Total } \\
\text { Projects/Permits }\end{array}$ & Number & $\begin{array}{c}\text { \% of Total of } \\
\text { Projects/Permits }\end{array}$ \\
\hline $\begin{array}{c}\text { New Development } \\
\text { Permits }\end{array}$ & 5,778 & 17 & $.3 \%$ & 5,761 & $99.7 \%$ \\
\hline ARO Projects & 153 & 12 & $8 \%$ & 141 & $92 \%$ \\
\hline $\begin{array}{c}\text { Ratio of New } \\
\text { Development Permits } \\
\text { to ARO Projects }\end{array}$ & $38: 1$ & $1.4: 1$ & & $41: 1$ & \\
\hline
\end{tabular}


Figure 23: ARO Projects Inside Higher-Intensity Land Use Districts

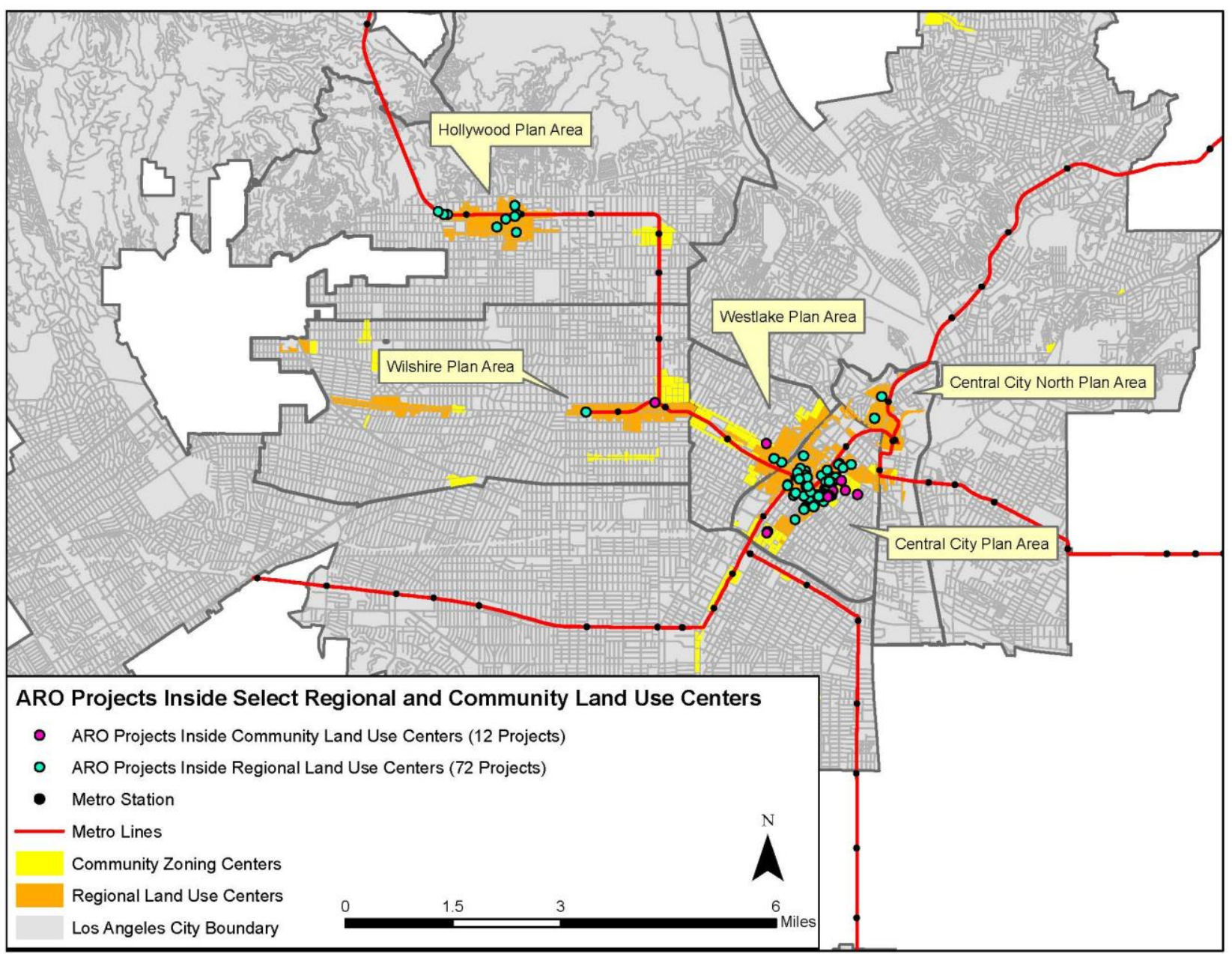


Figure 24: ARO Projects and New Development Inside Regional Centers

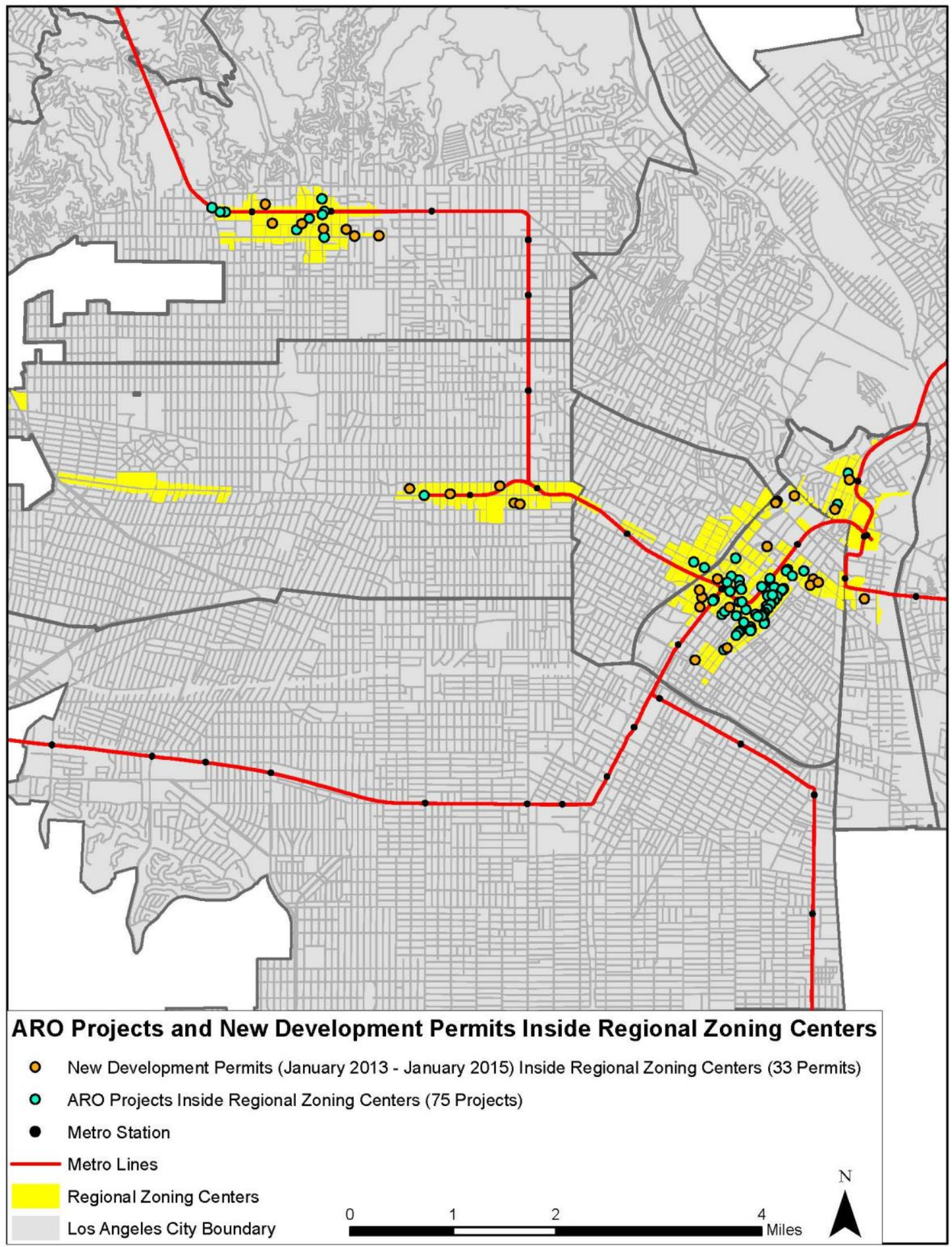


Figure 25: ARO Projects and New Development Inside Community Centers

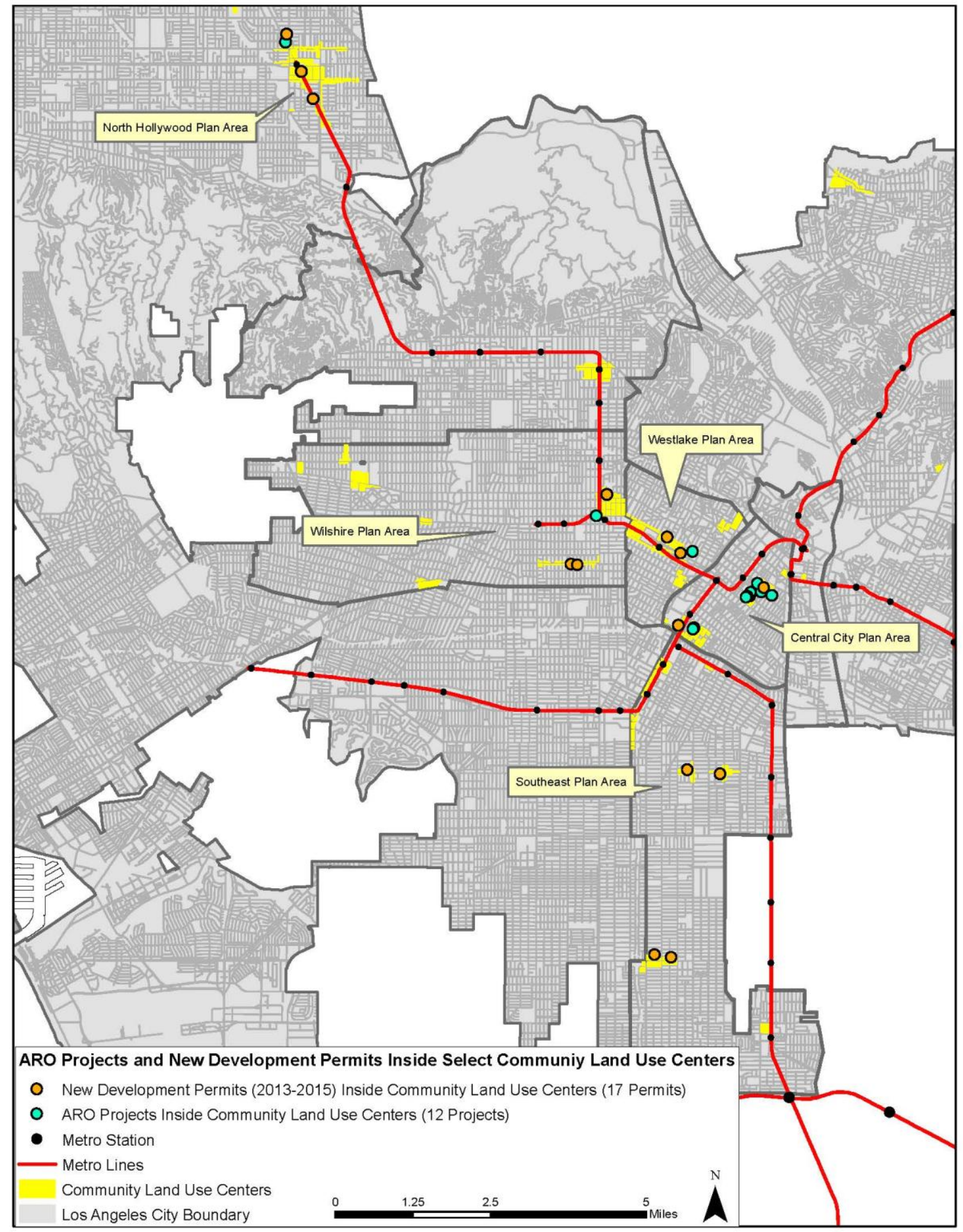




\section{Appendix E: ARO Project Data}

ARO Project 1-90 (Part One)

\begin{tabular}{|c|c|c|c|c|c|c|}
\hline Address & No. Stories & $\begin{array}{l}\text { No. Dwelling } \\
\text { Units }\end{array}$ & $\begin{array}{l}\text { Development } \\
\text { Date }\end{array}$ & Project Status & Permit Number & Conversion Use \\
\hline 565 W 5th St, Los Angeles, California, 90731 & 8 & 8 & 2005-2006 & $\mathrm{Cof} \mathrm{O}$ & 05016-10000-22122 & Joint live/work \\
\hline 550 S Hope St, Los Angeles, California, 90071 & 42 & 196 & 2006-2007 & Feasability Study & NA & Live/work units/commercial condominium units \\
\hline 1060 S Broadway, Los Angeles, California, 90015 & 10 & 82 & 2006 & Feasability_Study & NA & Residential_Condominium \\
\hline 108 W 2nd St, Los Angeles, California, 90012 & 10 & 143 & 2000-2001 & Issued-Permit Finaled & & Condo \\
\hline 111 W 7th St, Los Angeles, California, 90014 & 13 & 214 & 2006 & Cof 0 & 06016-10000-03785 & Live/Work \& Retail \\
\hline 112 W 2nd St, Los Angeles, California, 90012 & 1 & NA & NA & Cof $\mathrm{O}$ & 03016-10000-01059 & RESTAURANT / RETAIL \\
\hline $121 \mathrm{E}$ 6th St, Los Angeles, California, 90014 & 8 & 103 & 2005-2007 & Cof $\mathrm{O}$ & 02016-10000-10838 & Residential Condominium/commercial condominium \\
\hline 1291 W 6th St, Los Angeles, California, 90017 & 2 & 17 & 2005 & Cof $\mathrm{O}$ & 05016-10000-04618 & Artist in residence condominium lofts \& Joint Live/Work \\
\hline 1291 E 6th St, Los Angeles, California, 90021 & 2 & 11 & 2004-2005 & Cof 0 & 05016-10000-04618 & Joint live/work \\
\hline 1309 E 6th St, Los Angeles, California, 90021 & 1 & 1 & 2004-2006 & Cof $\mathrm{O}$ & 05016-10000-09436 & Artist in residence condominium lofts \\
\hline 1313 E 6th St, Los Angeles, California, 90021 & 1 & 19 & 2004-2005 & Cof $\mathrm{O}$ & 05016-10000-09441 & Joint live/work \\
\hline 2025 S Figueroa St, Los Angeles, California, 90007 & 3 & 9 & 2004 & Feasability Study & & Joint live/work \\
\hline 2135 E 7th PI, Los Angeles, California, 90021 & 2 & 19 & 2005-2006 & Issued-Permit Finaled & 05014-10000-07164 & Artist in residence condominium lofts \\
\hline 215 W 6th St, Los Angeles, California, 90014 & 14 & 196 & 2005 & $\mathrm{Cof} \mathrm{O}$ & 05016-10000-08939 & Residential Condominium/commercial condominium \\
\hline 215 W 7th St, Los Angeles, California, 90014 & 14 & 130 & 2001-2005 & Cof $\mathrm{O} \&$ Issued-Permit Finaled & 01016-10000-22560 \& & L Joint Live/Work \& commercial condominium \\
\hline 220 W 5th St, Los Angeles, California, 90013 & 10 & 62 & 2006 & Cof $\mathrm{O}$ & 06016-10000-03133 & Residential Condominium/commercial storefront \\
\hline 2222 S Figueroa St, Los Angeles, California, 90007 & 3 & 30 & 2003-2004 & Cof $\mathrm{O}$ & 03016-10000-01882 & Joint Live/work \\
\hline 225 W 8th St, Los Angeles, California, 90014 & 13 & 168 & 2006 & fEasability Study \& C of O & 06016-10000-01738 & Joint Live-Work Quarters/Residential Condominium/commercial \\
\hline 242 S Broadway, Los Angeles, California, 90012 & 5 & 38 & NA & Cof $\mathrm{O}$ & & Joint Live/work \\
\hline 245 W 7th St, Los Angeles, California, 90014 & 3 & 73 & $2005-2007$ & Feasability Study & 07042-10000-14177 (P & IResidential Condominium/commercial condominium \\
\hline 249 S Broadway, Los Angeles, California, 90012 & 5 & 40 & 2004-2005 & Cof $\mathrm{O}$ & & Live/work \& condominiums \\
\hline 263 W 7th St, Los Angeles, California, 90014 & 3 & 28 & $2006-2007$ & Feasability Study & 07042-10000-14177 (P & Residential Condominium/commercial condominium \\
\hline 308 E 9th St, Los Angeles, California, 90015 & 6 & 37 & 2007 & Cof $\mathrm{O}$ & 05016-10000-26347 & Live work/Office \\
\hline 312 W 5th St, Los Angeles, California, 90013 & 2 & 280 & 2002-2007 & Issued-Permit Issued & 02016-10000-01442 & Residential Condominium/commercial condominium \\
\hline 315 E 8th St, Los Angeles, California, 90014 & 12 & 64 & 2004 & cof 0 & 03016-10000-25380 & Residential Condominium/commercial condominium \\
\hline 315 W 5th St, Los Angeles, California, 90013 & 13 & 87 & 2005-2007 & Cof 0 & 05016-10000-12909 & Joint live/work \\
\hline 325 W 8th St, Los Angeles, California, 90014 & 6 & 91 & 2008 & 04016-10000-10888 & 04016-10000-10887 & Residential Condominium/commercial condominium \\
\hline 90013, Los Angeles, California & 1 & 59 & 2007 & Feasability Study & NA & Joint Live/work \\
\hline 404 S Figueroa St, Los Angeles, California, 90071 & 31 & 219 & 2006 & NA & NA & Residential Condominium/commercial condominium \\
\hline 411 W 5th St, Los Angeles, California, 90013 & 11 & 74 & 2006-2007 & Cof 0 & 05016-10000-04857 & Residential Condominium/commercial condominium \\
\hline 417 W 8th St, Los Angeles, California, 90014 & 3 & 2 & 2006 & Plan Check-Corrections Issued & 06016-10000-02073 & Joint live/work \\
\hline 421 Colyton St, Los Angeles, California, 90013 & 0 & 14 & 2007 & Feasability Study & 06016-10000-02222 & Artist in residence \\
\hline 424S Broadway, Los Angeles, California, 90013 & 10 & 60 & NA & Cof 0 & & NA \\
\hline 500 W 7th St, Los Angeles, California, 90014 & 0 & 55 & 2003 & Cof 0 & 03016-10000-08348 & Live/work \& Retail \\
\hline 510 S Broadway, Los Angeles, California, 90013 & 5 & 28 & 2005 & Plan Check-Corrections Issued & 05016-10000-02139 & Joint live/work \\
\hline 630 W 6th St, Los Angeles, California, 90017 & 6 & 90 & 2004-2005 & Issued-Permit Issued & 03016-10000-13964 & Residential Condominium/commercial storefront \\
\hline 711 Broadway, Los Angeles, California, 90012 & 4 & 42 & 2005 & Feasability Study & NA & Joint Live/Work \\
\hline 833 E 3rd St, Los Angeles, California, 90013 & 3 & 10 & 2007 & Feasability Study & NA & Joint Living and Work Quarter/Artist in residence condominium lc \\
\hline $846 \mathrm{~S}$ Broadway, Los Angeles, California, 90014 & 12 & 37 & 2002 & Cof 0 & & Live/work \\
\hline 849 S Broadway, Los Angeles, California, 90014 & 0 & 147 & 2004-2005 & Cof 0 & 04014-10000-09317 & Joint Live/work \\
\hline $901 \mathrm{~S}$ Broadway, Los Angeles, California, 90015 & 7 & 82 & 2002-2003 & Cof 0 & & Residential \\
\hline 940 E 2nd St, Los Angeles, California, 90012 & 12 & 88 & 2012 & Cof $\mathrm{O}$ & 06016-10000-24723 & Joint Living and Work Quarter \\
\hline 550 S Flower St, Los Angeles, California, 90071 & 12 & 207 & 2000 & Cof $\mathrm{O}$ & 00016-10000-15386 & Commercial hotel \\
\hline 612 S Flower St, Los Angeles, California, 90017 & 15 & 322 & 2002-2006 & Cof 0 & 02016-10000-05137 & Joint Live/work \& commercial condo \\
\hline 800 S Flower St, Los Angeles, California, 90017 & 12 & 251 & 2002-2003 & Issued-Permit Finaled & 02016-10000-19089 & Parking (830 Flower) \\
\hline 810 S Flower St, Los Angeles, California, 90017 & 0 & 100 & 2003 & Feasability Study & 03016-10000-13762 & Office \\
\hline 1140S Flower St, Los Angeles, California, 90015 & 6 & 91 & 2002 & Cof 0 & 02016-10000-04144 & Live/work \\
\hline $609 \mathrm{~S}$ Grand Ave, Los Angeles, California, 90017 & 13 & 99 & 2005 & feasability Study \& $C$ of $O$ & 05016-10000-07285 & Joint Live/Work \& Commercial/Retail Condominium \\
\hline $801 \mathrm{~S}$ Grand Ave, Los Angeles, California, 90017 & 22 & 132 & 2005 & $\mathrm{Cof} O$ & 05016-10000-02124 & Joint Live/Work \& Commercial/Office Condominium \\
\hline 816 S Grand Ave, Los Angeles, California, 90017 & 9 & 49 & 2005 & Cof $\mathrm{O}$ & 07016-10000-06024 & Residential Condominium \\
\hline 1043 S Grand Ave, Los Angeles, California, 90015 & 1 & 9 & 2003 & Cof 0 & & Live/work \\
\hline 1111S Grand Ave, Los Angeles, California, 90015 & 13 & 176 & 2003-2005 & Cof 0 & 04010-10000-03427 & Joint Live/Work \\
\hline 1155 S Grand Ave, Los Angeles, California, 90015 & 0 & 311 & 2006 & Cof 0 & & Live/work \& retail \\
\hline 1348 S Grand Ave, Los Angeles, California, 90015 & 0 & 314 & NA & Feasability Study & & NA \\
\hline 1358 S Grand Ave, Los Angeles, California, 90015 & 0 & & NA & Feasability Study & & NA \\
\hline 120 S Hewitt St, Los Angeles, California, 90012 & 2 & 33 & NA & Cof 0 & 05016-10000-13438 & Joint Live/Work \\
\hline 510 S Hewitt St, Los Angeles, California, 90013 & 6 & 63 & 2005-2006 & Issued-Permit Finaled & 05010-10000-06348 & Joint Live/Work \& Commercial Condominium \\
\hline 530 S Hewitt St, Los Angeles, California, 90013 & 5 & 179 & 2005-2006 & Cof 0 & 05016-10000-27225 & Joint live/work \\
\hline 701 S Hill St, Los Angeles, California, 90014 & 13 & 165 & NA & & & PIPELINE? \\
\hline 417 S Hill St, Los Angeles, California, 90013 & 12 & 277 & 2003 & Cof $\mathrm{O}$ & 03016-10000-02779 & LIVE/WORK \\
\hline 655 S Hope St, Los Angeles, California, 90017 & 17 & 80 & 2007 & Cof 0 & 06016-10000-25559 & Joint Live/Work \& Commercial Condominium \\
\hline 1000 S Hope St, Los Angeles, California, 90015 & 6 & 107 & 2002-2007 & Issued-Permit Finaled & 02016-10000-03661 \& & CJoint Live/Work \& Commercial Condominium \\
\hline 1100 S Hope St, Los Angeles, California, 90015 & 19 & 236 & 2005 & Cof 0 & 05010-10000-00589 & Joint Live/Work \\
\hline 2416 Hunter St, Los Angeles, California, 90021 & 0 & 20 & 2005 & Plan Check-Submitted & & Joint Live/Work \\
\hline 1855 Industrial St, Los Angeles, California, 90021 & 7 & 119 & 2003-2004 & Cof $\mathrm{O}$ & 03016-10001-00672 & Live/work residential \& commercial \\
\hline 1850 Industrial St, Los Angeles, California, 90021 & 8 & 104 & 2004-2005 & Issued-Permit Issued & & Joint Live/Work \& Commercial Condominium \\
\hline N Los Angeles St, Los Angeles, California, 90012 & 4 & 1 & 2002 & Feasability Study & 02016-10000-12647 & Live/work \& ground floor retail \\
\hline 700 S Los Angeles St, Los Angeles, California, 90014 & 5 & 64 & 2002 & Cof $\mathrm{O}$ & 02016-10000-12634 & Live/work \& ground floor retail \\
\hline 722 S Los Angeles St, Los Angeles, California, 90014 & 5 & 64 & 2002 & Cof 0 & 02016-10000-12639 & Live/work \& ground floor retail \\
\hline 730 S Los Angeles St, Los Angeles, California, 90014 & 6 & 72 & 2014 & & 14016-10000-11297 & Live/work \& ground floor retail \\
\hline 738 S Los Angeles St, Los Angeles, California, 90014 & 8 & 48 & 2002-2011 & Cof 0 & 04016-10000-17646 & Joint Live/Work \\
\hline 746 S Los Angeles St, Los Angeles, California, 90014 & 12 & 95 & 2002-2011 & Cof $\mathrm{O}$ & 04016-10000-17642 & Joint Live/Work \\
\hline 824 S Los Angeles St, Los Angeles, California, 90014 & 6 & 24 & 2002-2004 & Plan Check-Corrections Issued & 03016-10000-25383 & Joint Live/Work \& Ground floor retail \\
\hline 716 S Los Angeles St, Los Angeles, California, 90014 & 4 & 33 & 2002 & Cof $\mathrm{O}$ & 02016-10000-12654 & Joint live/work \\
\hline 400 S Main St, Los Angeles, California, 90013 & 9 & 70 & 1999-2000 & Cof 0 & 99016-10000-11484 & Apartments \\
\hline 530 S Main St, Los Angeles, California, 90013 & 4 & 70 & NA & Feasability Study & NA & NA \\
\hline 610S Main St, Los Angeles, California, 90014 & 10 & 314 & $2006-2008$ & Issued-Permit Issued & 02016-10000-13923 & Joint live/work \& commercial condominium \\
\hline 620 S Main St, Los Angeles, California, 90014 & 6 & 35 & 2004-2005 & Cof 0 & & Joint live/work \& commercial condominium \\
\hline 700 S Main St, Los Angeles, California, 90014 & 3 & 25 & 2003-2005 & Issued-Permit Finaled & 03010-30000-00955 & Joint Live/Work \\
\hline 1400 S Main St, Los Angeles, California, 90015 & 0 & 7 & 2005-2006 & Feasability Study & NA & Live/work \\
\hline 1772 N Main St, Los Angeles, California, 90031 & 2 & 5 & 2005-2006 & Cof $O$ & & Joint Live/Work \\
\hline 1210 Mateo St, Los Angeles, California, 90021 & 0 & 0 & & Feasability Study & & NA \\
\hline 500 Molino St, Los Angeles, California, 90013 & 0 & 91 & 2004-2006 & Feasability Study & 05016-10000-16753 & Joint Live/Work \\
\hline 1401 N Broadway, Los Angeles, California, 90012 & 0 & 6 & 2005 & Plan Check-Corrections Issued & 05014-10000-04507 & NA \\
\hline 1405 N Broadway, Los Angeles, California, 90012 & 1 & 1 & 2005 & Cof $\mathrm{O}$ & NA & Live/work \\
\hline 649 S Olive St, Los Angeles, California, 90014 & 13 & 117 & 2006-20007 & Feasability Study & NA & Joint Live/Work \& Commercial Condominium for retail space \\
\hline 409 W Olympic Blvd, Los Angeles, California, 90015 & 7 & 78 & 2007 & Cof 0 & 02016-10000-02981 & Apartments \\
\hline 2650 E Olympic Blvd, Los Angeles, California, 90023 & 9 & 1030 & 2014 & Feasability Study & NA & Proposed: 1030 UNITS OF LIVE/WORK UNITS, 219,258 SQ FT OF OFF \\
\hline $200 \mathrm{~N}$ San Fernando Rd, Los Angeles, California, 90031 & 7 & 102 & 2003-2006 & Cof $\mathrm{O}$ & 05016-10000-18552 & Live/work \& commercial condominium \\
\hline
\end{tabular}


ARO Project 1-90 (Part Two)

\begin{tabular}{|c|c|c|c|c|c|c|c|c|}
\hline Address & Commercial Units/Sq.Ft & Parking Spaces & Parcel Sq. Ft. & Building Sq. Ft. & Year Built & Location & Case Number & Historic Resource Status Code \\
\hline 565 W Sth St, Los Angeles, California, 90731 & NA & NA & 8254 & 210407 & $1950 \& 1960$ & Downtown & PERMIT NUMBER & NA \\
\hline 550 S Hope St, Los Angeles, California, 90071 & 135 & 712 & 447 & 832049 & 1967 & Downtown & VTT-67816 & NA \\
\hline 1060 S Broadway, Los Angeles, California, 90015 & NA & NA & 8421 & 80800 & 1925 & Downtown & VTT-65433 & NA \\
\hline 108 W 2nd St, Los Angeles, California, 90012 & none & NA & 19155 & 2290 & 1910 & & $\pi-53327$ & NA \\
\hline 111 W 7th St, Los Angeles, California, 90014 & 6528.00 SQ. FT. OF RETAIL & NA & 13305.3 & 3 buildings & 1926/1928/1962 & Downtown & $\pi-65767-\mathrm{CC}$ & 252 \\
\hline 112 W 2nd St, Los Angeles, California, 90012 & 884 S.F & NA & 58181 & NA & $\mathrm{NA}$ & No & PERMIT NUMBER & NA \\
\hline 121 E Gth St, Los Angeles, California, 90014 & 9 & 45 & 17651 & 213560 & 1911 & Downtown & VTT-65037-CC & 253 \\
\hline 1291 W 6th St, Los Angeles, California, 90017 & None & 0 & 6728 & 11560 & 1923 & No & ZA-1999-58-ZAI & NA \\
\hline 1291 E 6th St, Los Angeles, California, 90021 & None & 0 & 6728 & 12500 & 1923 & No & ZA-1999-58-ZAI & NA \\
\hline 1309 E Gth St, Los Angeles, California, 90021 & NA & NA & NA & NA & NA & NA & PERMIT NUMBER & NA \\
\hline 1313 E 6th St, Los Angeles, California, 90021 & None & 65 & 6728 & $30(1,339$ square feet for & 1923 & No & A-2004-4308-ZAA-ZAD-SF & NA \\
\hline 2025 S Figueroa St, Los Angeles, California, 90007 & & 78 & 7989 & 51612 & 1926 & Downtown & ZA-2004-935-ZAD & NA \\
\hline 2135 E 7th Pl, Los Angeles, California, 90021 & none & NA & 22600 & 1260 & 1922 & No & VTT-66674 & NA \\
\hline 215 W 6th St, Los Angeles, California, 90014 & 11 & NA & 19843 & 210407 & 1910 & Downtown & $\pi-62902$ & $1 \mathrm{D}$ \\
\hline 215 W 7th St, Los Angeles, California, 90014 & 1 & 12 & 15921 & 32500 & 1911 & Downtown & Tा-54121-CC & $10 / 2 D 3$ \\
\hline 220 W 5th St, Los Angeles, California, 90013 & 1 & NA & 11900 & 9450 & 1912 & Downtown & $\pi-62472-\mathrm{CC}$ & is \\
\hline 22225 Figueroa St, Los Angeles, California, 90007 & none & 49 & 168030 & 3 buildings & 1968 & Downtown & ZA-2003-2333-ZAD & NA \\
\hline 225 W 8th St, Los Angeles, California, 90014 & 13 retail spaces ground fllor & NA & 15508 & 8570 & 1913 & Downtown & $\pi-62954$ & is \\
\hline 2425 Broadway, Los Angeles, California, 90012 & & NA & 10090 & 41180 & 1914 & Downtown & & 203 \\
\hline 245 W 7th St, Los Angeles, California, 90014 & 6 & NA & 5246 & 1110 & 2009 & No & $\pi-62632$ & NA \\
\hline 249 S Broadway, Los Angeles, California, 90012 & 3 & NA & 13196 & 6640 & 1897 & Downtown & $\pi-62001-C C$ & $1 \mathrm{D}$ \\
\hline 263 W 7th St, Los Angeles, California, 90014 & 6 & NA & 5246 & 1110 & 2009 & No & $\pi-62632$ & NA \\
\hline 308 E 9th St, Los Angeles, California, 90015 & 2 & 0 & 7259 & 70700 & 1922 & Downtown & ZA-2006-501-ZAD & NA \\
\hline 312 W 5th St, Los Angeles, California, 90013 & 1 & 12 & 27211 & 960 & 1923 & Downtown & $\pi-54120-\mathrm{CC}$ & is \\
\hline 315 E 8th St, Los Angeles, California, 90014 & 1 & NA & 7339 & NA & NA & Downtown & VTT-53872 & 253 \\
\hline 315 W Sth St, Los Angeles, California, 90013 & NA & NA & 19144 & 161232 & 1913 & Downtown & PERMIT NUMBER & $1 \mathrm{D}$ \\
\hline 325 W 8th St, Los Angeles, California, 90014 & 4 & NA & 7339 & $\mathrm{NA}$ & 1928 & Downtown & VTT-68043-CC & 253 \\
\hline 90013, Los Angeles, California & none & 59 & 23663 & 23665 & NA & No & ZA-2006-5928-ZAD-SPR & No \\
\hline 404 S Figueroa St, Los Angeles, California, 90071 & 136 & 393 & 154257 & 4 buildings & 1976 & Downtown & $\mathrm{VTT-65986-CC}$ & NA \\
\hline 411 W Sth St, Los Angeles, California, 90013 & 1 (1,680 square feet) & NA & 10291 & 111113 & 1930 & Downtown & VTT-68170 & is \\
\hline 417 W 8th St, Los Angeles, California, 90014 & NA & NA & 2858 & 8826 & 1905 & Downtown & PERMIT NUMBER & NA \\
\hline 421 Colyton St, Los Angeles, California, 90013 & None & Minimum 1 per unit & 7503 & 31000 & 1909 & no & VTT-68901 & NA \\
\hline $424 \mathrm{~S}$ Broadway, Los Angeles, California, 90013 & NA & NA & 9006 & 4624 & 1906 & Downtown & ZA-2004-7710-ZAI & is \\
\hline 500 W 7th St, Los Angeles, California, 90014 & NA & NA & 10128.5 & 36882 & 1917 & Downtown & PERMIT NUMBER & NA \\
\hline 510 S Broadway, Los Angeles, California, 90013 & NA & NA & 8092 & 36975 & 1905 & Downtown & NA & is \\
\hline 630 W Gth St, Los Angeles, California, 90017 & 221 square feet of retail spa & 87 & 26752 & NA & NA & Downtown & VTT-62036 & NA \\
\hline $711 \mathrm{~N}$ Broadway, Los Angeles, California, 90012 & NA & 131 & 19444 & 55377 & 1989 & & ZA-2005-2601-ZAD & NA \\
\hline 833 E 3rd St, Los Angeles, California, 90013 & & 10 on site & 4856 & 26980 & 1930 & No & ZA-2007-1742-ZAD & NA \\
\hline 8465 Broadway, Los Angeles, California, 90014 & NA & NA & 9803 & 98096 & 1927 & Downtown & ZA-2003-5444-ZAI & is \\
\hline 8495 Broadway, Los Angeles, California, 90014 & NA & 4 & 22872 & 1640 & 1930 & Downtown & 61499 (Subdivision/PMC & is \\
\hline $901 \mathrm{~S}$ Broadway, Los Angeles, California, 90015 & NA & 0 & 7146 & 87017 & 1917 & Downtown & & 1D \\
\hline 940 E 2nd St, Los Angeles, California, 90012 & & 39 & 48473 & 2540 & 1906 & although required $\mathrm{HP}$ rev & v ZA-2006-7044-ZV-rV & 252 \\
\hline 550 S Flower St, Los Angeles, California, 90071 & 207 & 50 & 7920 & 172197 & 1956 & Downtown & ZA-2000-3103-ZV & 15 \\
\hline 612 F Flower St, Los Angeles, California, 90017 & 4 & 53 & 47331 & 483140 & 1949 & Downtown & VTT-62588-CC & 15 \\
\hline 800 S Flower St, Los Angeles, California, 90017 & 1 floor (3353 SQFT) & 632 & 8380 & 3 different dates & 3 different dates & Downtown & ZA-2003-786-CUB-ZV-SPF & 253 \\
\hline 810 S Flower St, Los Angeles, California, 90017 & 1 floor (3353 SQFT) & NA & 9140 & 3 different dates & 3 different dates & Downtown & PERMIT NUMBER & 253 \\
\hline 1140 S Flower St, Los Angeles, California, 90015 & NA & NA & NA & $\mathrm{NA}$ & NA & NA & PERMIT NUMBER & NA \\
\hline $609 \mathrm{~S}$ Grand Ave, Los Angeles, California, 90017 & 3 & 2 & 10494 & 131433 & 1925 & Downtown & $\pi-62955-\mathrm{CC}$ & $2 B$ or $2 \mathrm{D}$ (does not specify) \\
\hline 8015 Grand Ave, Los Angeles, California, 90017 & 1 & 264 & 58906 & 222947 & 1985 & Downtown & VTT-61917 & NA \\
\hline $816 \mathrm{~S}$ Grand Ave, Los Angeles, California, 90017 & NA & 15 & 3896 & 58686 & 1924 & Downtown & त-60206-CC & 252 \\
\hline 1043 S Grand Ave, Los Angeles, California, 90015 & NA & NA & 7654 & 7500 & 1928 & Downtown & PERMIT NUMBER & NA \\
\hline 1111 S Grand Ave, Los Angeles, California, 90015 & NA & NA & 38674 & & 2005 & Downtown & VTT-60746 & NA \\
\hline $1155 \mathrm{~S}$ Grand Ave, Los Angeles, California, 90015 & NA & NA & 51683 & 2170 & 2008 & Downtown & PERMIT NUMBER & NA \\
\hline $1348 \mathrm{~S}$ Grand Ave, Los Angeles, California, 90015 & NA & NA & 2778 & 2767 & 1924 & Downtown & ZA-2004-7710-ZAI & NA \\
\hline 1358 S Grand Ave, Los Angeles, California, 90015 & NA & NA & 2245 & 2200 & 1925 & Downtown & ZA-2004-7710-ZAI & NA \\
\hline os Angeles, California, 90012 & NA & 34 & 43522 & 1363 & 1948 & No & VTT-66170 & NA \\
\hline 510 S Hewitt St, Los Angeles, California, 90013 & Iy 3,131 square feet or 3 con & 303 & 39180 & 2830 & 1920 & No & 4-2005-3672-ZAD-ZAA-SP & NA \\
\hline 530 S Hewitt St, Los Angeles, California, 90013 & NA & NA & 8440 & cording to ZA determinat & 1920 & No & VTा-63027-CC & \\
\hline $701 \mathrm{~S}$ Hill St, Los Angeles, California, 90014 & PIPELINE? & PIPELINE? & & & & & & \\
\hline 4175 Hill St, Los Angeles, California, 90013 & NA & NA & 72230 & No data & NA & Downtown & ZA-2003-2347-ZAI & 252 \\
\hline $655 \mathrm{~S}$ Hope St, Los Angeles, California, 90017 & 14 & 84 & 11674 & 7890 & 1964 & Downtown & VTT-67656 & NA \\
\hline 1000 S Hope St, Los Angeles, California, 90015 & 8 & 180 & 39608 & 6870 & 1928 & Downtown & VTT-61799 & NA \\
\hline 1100 S Hope St, Los Angeles, California, 90015 & NA & 236 & 41120 & 84334 & 2007 & Downtown & VTT-60746 & NA \\
\hline 2416 Hunter St, Los Angeles, California, 90021 & NA & 0 & 5600 & 13800 & 1909 & No & ZA-2009-526-ZAD & NA \\
\hline 1855 Industrial St, Los Angeles, California, 90021 & 3 & NA & 42676 & $19=$ & 19 & No & $\pi-54050-\mathrm{CC}$ & NA \\
\hline 1850 Industrial St, Los Angeles, California, 90021 & 4 & 290 & 32238 & 2070 & 1925 & No & ZA-2004-3332-ZVV-ZAD-SP & 15 \\
\hline $\mathrm{N}$ Los Angeles St, Los Angeles, California, 90012 & $\begin{array}{l}4 \\
\text { re feet of ground floor ret }\end{array}$ & 128 & 7001 & $225.0 \& 82,650.0 \& 41,00$ & c $1912,1912,1912$ & Downtown & ZA-2002-3944-ZV & 551 \\
\hline & tare feet of ground floor ret. & 128 & 7001 & $225.0 \& 82,650.0 \& 41,0 C$ & c $1912,1912,1912$ & Downtown & ZA-2002-3944-ZV & 551 \\
\hline 722 L Los Angeles St, Los Angeles, California, 90014 & uare feet of ground floor ret & 128 & 7001 & $225.0 \& 82,650.0 \& 41,0 C$ & C $1912,1912,1912$ & Downtown & ZA-2002-3944-ZV & 551 \\
\hline 730 S Los Angeles St, Los Angeles, California, 90014 & uare feet of ground floor ret: & 128 & 7001 & $225.0 \& 82,650.0 \& 41,0 C$ & c $1912,1912,1912$ & Downtown & ZA-2002-3944-ZV & 551 \\
\hline 738 S Los Angeles St, Los Angeles, California, 90014 & NA & 128 & 38263 & NA & NA & Downtown & ZA-2002-3944-ZV & 551 \\
\hline 746 S Los Angeles St, Los Angeles, California, 90014 & NA & 128 & 38263 & NA & NA & Downtown & ZA-2002-3944-ZV & 551 \\
\hline 824 L Los Angeles St, Los Angeles, California, 90014 & NA & NA & 3128.8 & 37746 & 1926 & Downtown & & 551 \\
\hline $716 \mathrm{~S}$ Los Angeles St, Los Angeles, California, 90014 & $T^{N A}$ & TNA & 7001 & $225.0 \& 82,650.0 \& 41,0 C$ & c $1912,1912,1912$ & Downtown & ZA-2002-3944-ZV & 551 \\
\hline 400 S Main St, Los Angeles, California, 90013 & NA & NA & 7990 & 131161 & 1907 & Downtown & NA-SEE PERMIT NUMBER & 253 \\
\hline 530 S Main St, Los Angeles, California, 90013 & NA & NA & & & & & & \\
\hline 610 S Main St, Los Angeles, California, 90014 & 1 & 83 & 62335 & 388144 & 1904 & Downtown & VTT-68242-CC & 551 \\
\hline 620 S Main St, Los Angeles, California, 90014 & 1 & 35 & 12841 & 580 & 1906 & Downtown & VTT-61627 & NA \\
\hline 700 S Main St, Los Angeles, California, 90014 & NA & 'arking garage constructec & 2970 & 48096 & 1904 & Downtown & SEE PERMIT NUMBER & NA \\
\hline 1400 S Main St, Los Angeles, California, 90015 & NA & 0 & 6261 & 26146 & 1902 & Downtown & & NA \\
\hline 1772 N Main St, Los Angeles, California, 90031 & No & 11 & 4050 & 2380 & 1890 & No & ZA-2005-1005-ZAD & NA \\
\hline 1210 Mateo St, Los Angeles, California, 90021 & NA & NA & & & & & & \\
\hline 500 Molino St, Los Angeles, California, 90013 & None & 95 & 83432 & 1730 & 1923 & No & VTT-60507-CC & NA \\
\hline $1401 \mathrm{~N}$ Broadway, Los Angeles, California, 90012 & NA & NA & 7408 & 4704 & 1920 & YES & NA & NA \\
\hline $1405 \mathrm{~N}$ Broadway, Los Angeles, California, 90012 & NA & NA & NA & NA & NA & NA & NA & NA \\
\hline 649 S Olive St, Los Angeles, California, 90014 & $30(32,480$ square & 0 & 13376 & NA & NA & Downtown & VTT-66908-CC & loes not specify) \\
\hline 409 W Olympic Blvd, Los Angeles, California, 900 & NA & NA & 6 & 126 & 1929 & Downtown & PERMIT NUMBER & is \\
\hline 2650 E Olympic Blvd, Los Angeles, California, 90023 & NOT YET AVALALBLE & NOT YET AVAILABLE & 400508 & 1844445 & 1927 & None & ZA-2014-3054-ZAD & 252 \\
\hline $200 \mathrm{~N}$ San Fernando Rd, Los Angeles, California, 90031 & 6 & 146 Minimum & 63127 & 1060 & 1925 & Yes & VTT-54263-CC & NA \\
\hline
\end{tabular}


ARO Project 90-154 (Part One)

\begin{tabular}{|c|c|c|c|c|c|c|}
\hline Address & No. Stories & $\begin{array}{l}\text { No. Dwelling } \\
\text { Units }\end{array}$ & $\begin{array}{l}\text { Development } \\
\text { Date }\end{array}$ & Project Status & Permit Number & Conversion Use \\
\hline 420 S San Pedro St, Los Angeles, California, 90013 & 6 & 161 & 2002-2003 & $\mathrm{Cof} O$ & 01016-10000-20084 & Live/work \& commercial condominium \\
\hline 434 S San Pedro St, Los Angeles, California, 90013 & 0 & 75 & 2007 & Feasability Study & NA & Downtown Womens Center \& Residential \& Ground Floor Comme \\
\hline 441 S San Pedro St, Los Angeles, California, 90013 & 6 & 8 & 2002-2005 & Issued-Permit Issued & 05016-30000-13726 & Artist in residence \\
\hline $100 \mathrm{~N}$ Santa Fe Ave, Los Angeles, California, 90012 & 0 & 8 & 2005-2006 & Plan Check-Corrections Issued & 05014-10000-05195 & Joint Live/Work \\
\hline 743 Santee St, Los Angeles, California, 90014 & 11 & 73 & 2004-2005 & Cof $\mathrm{O}$ & 04016-10000-17641 & Joint Live/Work \& Ground floor retail \\
\hline 840 Santee St, Los Angeles, California, 90014 & 8 & 50 & 2006-2007 & Plan Check-Submitted & 06016-10000-19162 & Joint live/work and commercial condominium \\
\hline 1010S Santee St, Los Angeles, California, 90015 & 4 & 8 & 2004-2006 & Plan Check-Corrections Issued & 06016-10000-02386 & Joint live/work and commercial condominium \\
\hline 420 Seaton St, Los Angeles, California, 90013 & 0 & 72 & 2013 & Feasability Study & NA & Joint Live/Work \\
\hline 1231 N Spring St, Los Angeles, California, 90012 & 5 & 12 & NA & Feasability Study & 00016-10000-08378 & OFFICE, COMMERCIAL ARTIST LOFTS AND WARHOUSE SPACES. \\
\hline 257 S Spring St, Los Angeles, California, 90012 & 5 & 50 & 2003-2004 & Cof $\mathrm{O}$ & 03016-10000-08711 & Live/work \& commercial condominium \\
\hline 408 S Spring St, Los Angeles, California, 90013 & 13 & 57 & 1999-2000 & $\mathrm{Cof} O$ & 99016-10000-11488 & Apartments \\
\hline 410 S Spring St, Los Angeles, California, 90013 & 7 & 113 & 1999-2001 & Cof 0 & 99016-10000-11491 & Apartments \\
\hline 416 S Spring St, Los Angeles, California, 90013 & 12 & 65 & 2005 & Cof $\mathrm{O}$ & 05016-10000-03417 & Condo \& Commercial/Retail \\
\hline 419 S Spring St, Los Angeles, California, 90013 & 0 & 180 & 2008-2009 & Feasability Study & 08016-10000-04457 & HOTEL \\
\hline 460 S Spring St, Los Angeles, California, 90013 & 13 & 200 & 2005 & Cof 0 & 02016-10000-25181 & Residential \& Commercial \\
\hline 510 S Spring St, Los Angeles, California, 90013 & 12 & 153 & 2002 & Cof $\mathrm{O}$ & 02016-10000-15936 & Joint live/work \\
\hline 541 S Spring St, Los Angeles, California, 90013 & 12 & 143 & 2002-2006 & Cof $\mathrm{O}$ & 02016-10000-19090 & Residential \& Commercial \\
\hline 548 S Spring St, Los Angeles, California, 90013 & 13 & 154 & 2003-2007 & Issued-Permit Finaled & 03016-10000-13524 & Change of use - NA \\
\hline 600 S Spring St, Los Angeles, California, 90014 & 19 & 256 & 2006-2007 & Issued-Permit Issued & 06016-10000-23091 & Residential \& Commercial \\
\hline 626 S Spring St, Los Angeles, California, 90014 & 6 & 35 & 2001-2004 & Cof $\mathrm{O}$ & 01016-10000-04242 & Residential \& Commercial \\
\hline 639 S Spring St, Los Angeles, California, 90014 & 13 & 37 & 2001-2005 & Cof $\mathrm{O}$ & 05016-20000-22741 & Condominium \\
\hline 650 S Spring St, Los Angeles, California, 90014 & 19 & 178 & 2007-2009 & $\mathrm{Cof} O$ & 06016-10001-03786 & PROJECT TERMINATED \\
\hline 90014, Los Angeles, California & 13 & 72 & 2006-2007 & Cof $\mathrm{O}$ & 06016-10000-18634 & Residential/Commercial Condominium \\
\hline 215 W 5th St, Los Angeles, California, 90013 & 9 & 88 & 2006-2007 & Cof O & 06016-10000-18634 & Residential Condominium/commercial storefront \\
\hline 810 S Spring St, Los Angeles, California, 90014 & 13 & 93 & 2006 & Cof $\mathrm{O}$ & 06016-10000-01204 & Joint live/work \& Commercial Condominium \\
\hline 812 S Spring St, Los Angeles, California, 90014 & 8 & 7 & 2002-2005 & Cof $\mathrm{O}$ & & Residential/Commercial Condominium \\
\hline 949 Sun Mun Way, Los Angeles, California, 90012 & 3 & 2 & 2004 & Cof $\mathrm{O}$ & & RECENT ACTIVITY \\
\hline 1111 W Sunset Blvd, Los Angeles, California, 90012 & 9 & 71 & 2004-2007 & Issued-Permit Issued & 05016-10000-01868 & Joint Live/Work \\
\hline 3111 Via Dolce, Los Angeles, California, 90292 & 9 & 72 & 2005-2007 & Cof $\mathrm{O}$ & 05014-10000-09711 & Joint Live/Work \\
\hline 1010 Wilshire Blvd, Los Angeles, California, 90017 & 17 & 227 & 2006-2007 & Cof 0 & 05016-10000-26768 & Live/work condominium \\
\hline 1100 Wilshire Blvd, Los Angeles, California, 90017 & 35 & 228 & 2005 & Cof $\mathrm{O}$ & & Live/work \\
\hline 1617 Cosmo St, Los Angeles, California, 90028 & 5 & 47 & 2004 & C of O \& Plan Check - Corrections I & $\leq 03014-10000-07702$ & RECENT ACTIVITY \\
\hline 1800 Argyle Ave, Los Angeles, California, 90028 & 5 & 59 & 2014 & Feasability Study & NA & RECENT ACTIVITY \\
\hline 6253 Hollywood Blvd, Los Angeles, California, 90028 & 12 & 60 & 2003-2005 & Cof $\mathrm{O}$ & 04016-10000-02870 & Residential/Commercial Condominium \\
\hline 7046 Hollywood Blvd, Los Angeles, California, 90028 & 8 & 42 & 2005-2006 & Cof $\mathrm{O}$ & 05016-10000-10792 & NA \\
\hline 7060 Hollywood Blvd, Los Angeles, California, 90028 & 12 & 42 & NA & NA & NA & Residential/Commercial Condominium \\
\hline 1718 N La Brea Ave, Los Angeles, California, 90046 & 2 & 1 & 2003 & Cof $\mathrm{O}$ & 03016-10000-15934 & NA \\
\hline 5473 Santa Monica Blvd, Los Angeles, California, 90029 & 4 & 27 & 2003-2004 & Cof $\mathrm{O}$ & 03016-10000-15798 & AFFORDABLE HOUSING APARTMENT \\
\hline 6290 W Sunset Blvd, Los Angeles, California, 90028 & 19 & 63 & 2005-2008 & Cof $\mathrm{O}$ & 05016-10000-02806 & Joint live/work \& Commercial Condo "for signage purposes" \& Co \\
\hline 1645 Vine St, Los Angeles, California, 90028 & 10 & 96 & 2005 & Cof $\mathrm{O}$ & 05016-10000-03718 & Joint Live/work \& commercial condo \\
\hline 1777 Vine St, Los Angeles, California, 90028 & 5 & 96 & 2014 & Feasability Study & NA & NA \\
\hline $201 \mathrm{~N}$ Westmoreland Ave, Los Angeles, California, 9000 & .2 & 31 & 2005-2006 & Issued-Permit Finaled & 05016-10000-22135 & Artists residence \\
\hline 1545 Wilcox Ave, Los Angeles, California, 90028 & 3 & 0 & 2014 & Feasability Study & & RECENT ACTIVITY \\
\hline 5355 Cartwright Ave, Los Angeles, California, 91601 & 4 & 68 & 2003-2004 & $\mathrm{Cof} O$ & 03016-10000-22443 & Joint Live/Work \\
\hline 5657 Lankershim Blvd, Los Angeles, California, 91601 & 1 & 5 & & Feasability Study & & NA \\
\hline 1839 Blake Ave, Los Angeles, California, 90039 & 0 & 13 & 2004 & Issued-Permit Finaled & 04014-10000-01766 & Joint Live/work \\
\hline 1849 Blake Ave, Los Angeles, California, 90039 & 0 & 14 & NA & Feasability Study & & NA \\
\hline 212 W Avenue 26, Los Angeles, California, 90031 & 0 & 26 & 2014 & NA & NA & RECENT ACTIVITY \\
\hline 2450 Daly St, Los Angeles, California, 90031 & 2 & 10 & 2005 & Plan Check-PC Approved & & Joint live/work (RECENT ACTIVITY) \\
\hline 2701 N Broadway, Los Angeles, California, 90031 & 3 & 50 & 2014 & NA & NA & RECENT ACTIVITY \\
\hline 6301 N Figueroa St, Los Angeles, California, 90042 & 2 & 12 & 2005-2007 & Cof 0 & 06016-10000-06969 & Live/work residential condominiums \\
\hline 1755 Glendale Blvd, Los Angeles, California, 90026 & 3 & 22 & 2006-2007 & Plan Check-Submitted & 06016-10000-22567 & Residential Condominium \\
\hline 2972 Glendale Blvd, Los Angeles, California, 90039 & 0 & 0 & 2005-2006 & Feasability Study & 05016-10000-11976 & Live/work \\
\hline 2327 W 54th St, Los Angeles, California, 90043 & 2 & 37 & NA & Feasability Study & NA & NA \\
\hline 2203 S Union Ave, Los Angeles, California, 90007 & 1 & 84 & & Issued-Permit Issued & & NA \\
\hline 1324 Abbot Kinney Blvd, Los Angeles, California, 90291 & 3 & 1 & 1999 & Issued-Permit Finaled & 99010-10001-00314 & NA \\
\hline 815 Hampton Dr, Los Angeles, California, 90291 & 2 & 10 & 2003-2005 & Issued-Permit Finaled & 03010-30000-00956 & Artist in residence \\
\hline 1046 Princeton Dr, Los Angeles, California, 90292 & 3 & 30 & 2006-2008 & Cof $\mathrm{O}$ & & Live/work \\
\hline 1809 Washington Way, Los Angeles, California, 90291 & 2 & 1 & 2005 & Issued-Permit Finaled & & NA \\
\hline 11500 Tennessee Ave, Los Angeles, California, 90064 & 4 & 84 & 2005-2008 & $\mathrm{Cof} O$ & & NEW BUIOLDING Joint Live/Work \\
\hline 3223 W 6th St, Los Angeles, California, 90020 & 12 & 85 & 2006-2007 & Issued-Permit Finaled & 06016-10000-15761 & Senior citizen housing \\
\hline 4007 W 6th St, Los Angeles, California, 90020 & 2 & 9 & 2005 & Cof $\mathrm{O}$ & \multicolumn{2}{|l|}{ 05016-10000-00942 } \\
\hline 5979 W 3rd St, Los Angeles, California, 90036 & 2 & 11 & 2004 & Plan Check-Corrections Issued & & Residential Condominium/commerci \\
\hline 3800 Wilshire Blvd, Los Angeles, California, 90010 & 23 & 263 & 2005 & Issued-Permit Finaled & & Residential Condominium/commercia \\
\hline
\end{tabular}




\subsubsection{ARO Project 90-154 (Part Two)}

\begin{tabular}{|c|c|c|c|c|c|c|c|c|}
\hline Address & Commercial Units/Sq.Ft & Parking Spaces & Parcel Sq. Ft. & Building Sq. Ft. & Year Built & Location & Case Number & Historic Resource Status Code \\
\hline 420 S San Pedro St, Los Angeles, California, 90013 & 1 & 300 & 76256 & & 1922 & Downtown & $\pi-53922$ & 501 or 552 (does not specify) \\
\hline 434 S San Pedro St, Los Angeles, California, 90013 & 1,200 square feet of street- 1 & | 35 off-site & 14514 & 65308 & 1926 & Downtown & ZA-2007-1179-ZV-ZAA-SF & \\
\hline 441 S San Pedro St, Los Angeles, California, 90013 & No & NA & 19219 & 92538 & 1923 & Downtown & & NA \\
\hline 100 N Santa Fe Ave, Los Angeles, California, 90012 & No & 13 & 4425 & 19520 & 1937 & None & TT-62468-CC & NA \\
\hline 743 Santee St, Los Angeles, California, 90014 & 72,000 square feet of retail & ؛128 minimum & 38263 & NA & NA & Downtown & ZA-2001-4326-ZAD & 252 \\
\hline 840 Santee St, Los Angeles, California, 90014 & 7 & NA & 5015 & 95700 & 1926 & Downtown & & NA \\
\hline 1010 S Santee St, Los Angeles, California, 90015 & 0 & 0 & 7113 & 26400 & 1929 & Downtown & ZA-2004-3445-ZAD & NA \\
\hline 420 Seaton St, Los Angeles, California, 90013 & none & NA & NA & NA & NA & No & ZA-2013-362-ZAD & NA \\
\hline 1231 N Spring St, Los Angeles, California, 90012 & NA & NA & 54245 & 60821 & 1888 & YES & $\mathrm{NA}$ & 252 \\
\hline 257 S Spring St, Los Angeles, California, 90012 & 12 & NA & 28715 & NA & 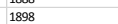 & Downtown & $\pi-60578$ & Under Consideration \\
\hline 408 S Spring St, Los Angeles, California, 90013 & NA & NA & 7075 & 77032 & 1904 & Downtown & SEE PERMIT NUMBER & is \\
\hline 410 S Spring St, Los Angeles, California, 90013 & NA & NA & 11888 & 74628 & 1909 & Downtown & SEE PERMIT NUMBER & 10 \\
\hline 416 S Spring St, Los Angeles, California, 90013 & 7 & NA & 10335 & 13230 & 1914 & Downtown & $\pi-63019-\mathrm{CC}$ & is \\
\hline 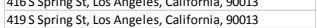 & NA & $\mathrm{NA}$ & 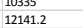 & $\begin{array}{l}13230 \\
121884\end{array}$ & $\begin{array}{l}1914 \\
1927\end{array}$ & $\begin{array}{l}\text { Downtown } \\
\text { Downtown }\end{array}$ & & 15 \\
\hline 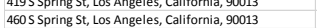 & $\begin{array}{l}\text { NA } \\
19\end{array}$ & NA & $\begin{array}{l}12141.2 \\
30825\end{array}$ & 1580 & $\begin{array}{l}1927 \\
1912\end{array}$ & $\begin{array}{l}\text { Downtown } \\
\text { Downtown }\end{array}$ & Tा-63018-CC & $\begin{array}{l}15 \\
10\end{array}$ \\
\hline 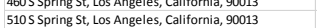 & NA & NA & $\begin{array}{l}3025 \\
19009\end{array}$ & $\begin{array}{l}1580 \\
214867\end{array}$ & $\begin{array}{l}1912 \\
1907\end{array}$ & $\begin{array}{l}\text { Downtown } \\
\text { Downtown }\end{array}$ & $\begin{array}{l}\text { I-630018-CC } \\
\text { SEE PERMIT NUMBER }\end{array}$ & 10 \\
\hline $\begin{array}{l}\text { S1SS Spring St, Los Angeles, alifornia, } \\
54 \text { S S Spring St, Los Angeles, California, } \\
90013\end{array}$ & $\begin{array}{l}\mathrm{NA} \\
1\end{array}$ & NA & $\begin{array}{l}19009 \\
48671\end{array}$ & 621860 & $\begin{array}{l}1907 \\
1923\end{array}$ & $\begin{array}{l}\text { Downtown } \\
\text { Downtown }\end{array}$ & $\begin{array}{l}\text { SEPERRMTIUMMBER } \\
\pi-62470-C C\end{array}$ & 10 \\
\hline 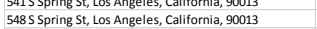 & ${ }_{\mathrm{NA}}^{1}$ & NA & $\begin{array}{l}48661 \\
18854\end{array}$ & $\begin{array}{l}62680 \\
18894\end{array}$ & $\begin{array}{l}1923 \\
1914\end{array}$ & $\begin{array}{l}\text { Downtown } \\
\text { Downtown }\end{array}$ & $\begin{array}{l}\text { T1-6240-CC } \\
\text { SEE PERMIT NUMBER }\end{array}$ & 10 \\
\hline 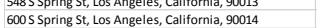 & 13 & 208 & 18584 & $\begin{array}{l}1888944 \\
346187\end{array}$ & $\begin{array}{l}1914 \\
1959\end{array}$ & $\begin{array}{l}\text { Downtown } \\
\text { Downtown }\end{array}$ & $\pi-64779-C C$ & is \\
\hline 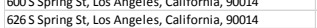 & $\begin{array}{l}13 \\
2\end{array}$ & ${ }_{\mathrm{NA}}^{208}$ & $\begin{array}{l}11426 \\
8194\end{array}$ & $\begin{array}{l}341837 \\
45396\end{array}$ & $\begin{array}{l}1959 \\
1912\end{array}$ & $\begin{array}{l}\text { Downtown } \\
\text { Downtown }\end{array}$ & $\pi-60612-\mathrm{CC}$ & $\begin{array}{l}15 \\
10\end{array}$ \\
\hline 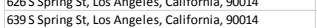 & None & NA & $\begin{array}{l}81944 \\
10841\end{array}$ & $\begin{array}{l}4231274 \\
121274\end{array}$ & ${ }_{1929}^{1929}$ & $\begin{array}{l}\text { Downtown } \\
\text { Downtown }\end{array}$ & TT-533128-CC & 10 \\
\hline 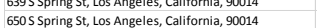 & $\begin{array}{l}\text { None } \\
\text { PROJECT TERMINATED }\end{array}$ & $\begin{array}{l}\text { NA } \\
\text { PROJECT TERMINATED }\end{array}$ & $\begin{array}{l}10441 \\
20160\end{array}$ & $\begin{array}{l}121274 \\
219556\end{array}$ & ${ }_{1928}^{1929}$ & $\begin{array}{l}\text { Downtown } \\
\text { Downtown }\end{array}$ & TI-657367-CC & 10 \\
\hline 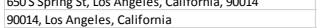 & $\begin{array}{l}\text { PROJECT TERMINATED } \\
4\end{array}$ & POOJECT TERMINATED & 6218 & 192356 & ${ }_{1923}^{1928}$ & $\begin{array}{l}\text { Downtown } \\
\text { Downtown }\end{array}$ & $\begin{array}{l}11-6767-\mathrm{-CC} \\
\mathrm{V} T \mathrm{~T}-6825 \mathrm{-CC}\end{array}$ & 501 or 552 (does not specify) \\
\hline $\begin{array}{l}\text { 90014, Los Angeles, Cailotrnia } \\
215 \text { W Sth St, Los Angeles, California, } 90013\end{array}$ & $\begin{array}{l}4 \\
1\end{array}$ & NA & $\begin{array}{l}6218 \\
12219\end{array}$ & $\begin{array}{l}1923 \\
10050\end{array}$ & ${ }_{1923}^{1923}$ & $\begin{array}{l}\text { Downtown } \\
\text { Downtown }\end{array}$ & TI-624271-CC & $\begin{array}{l}\text { S01 or } 552 \text { (does not specify) } \\
15\end{array}$ \\
\hline 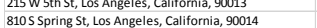 & $\begin{array}{l}1 \\
17\end{array}$ & $\begin{array}{l}\text { NA } \\
\text { NA }\end{array}$ & $\begin{array}{l}12219 \\
10305\end{array}$ & 1050 & $\begin{array}{l}1926 \\
1924\end{array}$ & $\begin{array}{l}\text { Downtown } \\
\text { Downtown }\end{array}$ & $\pi-65350-\mathrm{cc}$ & $\begin{array}{l}15 \\
501 \text { or } 552 \text { (does not specify) }\end{array}$ \\
\hline $\begin{array}{l}810 \text { Sppring St, Los A Ageles, adiforniai, } 90014 \\
812 \text { S Spring St, Los Angeles, Californaa, } 90014\end{array}$ & ${ }_{1}^{17}$ & ${ }_{0}^{N A}$ & $\begin{array}{l}10305 \\
2064\end{array}$ & 189802 & $\begin{array}{l}1924 \\
1914\end{array}$ & $\begin{array}{l}\text { Downtown } \\
\text { Downtown }\end{array}$ & $\begin{array}{l}\pi-65350-\mathrm{CC} \\
\pi-62819-\mathrm{Cc}\end{array}$ & $\begin{array}{l}501 \text { or } 52 \text { 2(does not s seefify) } \\
501 \text { or } 52 \text { (does not specify) }\end{array}$ \\
\hline $\begin{array}{l}812 \text { Sspring St, Los Angeles, Cailofrnia, } 90014 \\
949 \text { Sun Mun Way, Los Angeles, California, } 90012\end{array}$ & $\begin{array}{l}1 \\
\text { RECENT ACTIVITY }\end{array}$ & $\begin{array}{l}0 \\
\text { RECENT ACTIVITY }\end{array}$ & 3956 & $\begin{array}{l}1890 \\
7716\end{array}$ & $\begin{array}{l}1914 \\
1940\end{array}$ & $\begin{array}{l}\text { Downtown } \\
\text { Yes }\end{array}$ & $\begin{array}{l}\pi T-62819-\mathrm{CC} \\
\pi-6281-\mathrm{CC}\end{array}$ & $\begin{array}{l}\text { S01 } 1 \text { or } 552 \text { (does not specify) } \\
\text { NA }\end{array}$ \\
\hline $\begin{array}{l}949 \text { Sun Mun Wayy Los Angeles, California, } \\
1111 \text { W Sunset Blivd, Los Angeles, California, } \\
10012\end{array}$ & $\begin{array}{l}\text { REECNTACTIVITY } \\
\text { NA }\end{array}$ & $\begin{array}{l}\text { REEENTACTIVIT } \\
71\end{array}$ & 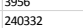 & $\begin{array}{l}7716 \\
65,140.0 \& 18,722.0\end{array}$ & $\begin{array}{l}1940 \\
1961 \& 1961\end{array}$ & $\begin{array}{l}\text { Yres } \\
\text { No }\end{array}$ & $\begin{array}{l}\text { I-1-282819-CC } \\
\text { ZA-2004-1323-AAD-ZAA }\end{array}$ & $\mathrm{NA}$ \\
\hline $\begin{array}{l}1111 \text { W } \text { Sunset tildd, Los Angeles, California, } 90012 \\
311 \text { Via Dolce, Los Angeles, California, } 902929\end{array}$ & $\begin{array}{l}\mathrm{NA} \\
\mathrm{NA}\end{array}$ & $\begin{array}{l}71 \\
184\end{array}$ & 240332 & $65,140.0 \& 18,722.0$ & $\begin{array}{l}19610 \& 1961 \\
2010\end{array}$ & $\begin{array}{l}\text { No } \\
\text { No }\end{array}$ & $\begin{array}{l}\text { ZAA-20044-1323-ZAD-ZAA } \\
\text { VT- }\end{array}$ & NA \\
\hline 1010 Wilshire Blvd, Los Angeles, California, 90017 & NA & 240 & 26040 & 1030 & 1960 & & VTा-62400 & NA \\
\hline 1100 Wilshire Blvd, Los Angeles, California, 90017 & NA & NA & 26987 & 27309 & 1986 & No & $\begin{array}{l}\text { SEE PERMIT NUMBER } \\
\text { SPCUN }\end{array}$ & NA \\
\hline 1617 Cosmo St Los Angeles, California, 90028 & RECENT ACTIVITY & $\begin{array}{l}\text { RA } \\
\text { RECENT ACTIVITY }\end{array}$ & 3250 & 42653 & 1980 & yes & RECENTACTVITY & 62 \\
\hline 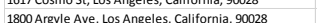 & $\begin{array}{l}\text { REEEN ACIVIY } \\
\text { RECENT ACTIVITY }\end{array}$ & $\begin{array}{l}\text { RECENIACIVIY } \\
\text { RECENTACTIVITY }\end{array}$ & 8619 & $\begin{array}{l}4 \text { Lb53 } \\
\text { building } 1: 37,359,0 \text {, buil }\end{array}$ & $\begin{array}{ll}19100 \\
\text { ill1961 }\end{array}$ & $\begin{array}{l}\text { yes } \\
\text { yes }\end{array}$ & & NA \\
\hline $\begin{array}{l}6253 \text { Hollywood Blyd, Los Angeles, California, } 90028 \\
6028\end{array}$ & 8 & NA & ${ }_{12619}^{2600}$ & 7700 & 1929 & $\begin{array}{l}\text { yes } \\
\text { Yes }\end{array}$ & $\pi-60544$ & $10 / 252$ \\
\hline 7046 Hollywood Blvo, Los Angeles, California, 90028 & NA & NA & 12679 & 51408 & 1925 & $\begin{array}{l}\text { Yres } \\
\text { Yes }\end{array}$ & & $10 / 2$ \\
\hline 7060 Hollywood Blvd, Los Angeles, California, 90028 & 8 & 170 & 10755 & 174804 & 1971 & yes & VT-66305-CC & NA \\
\hline $1718 \mathrm{~N}$ La Brea Ave, Los Angeles, California, 90046 & NA & NA & 5843 & 3984 & 1916 & $\begin{array}{l}\text { res } \\
\text { Yes }\end{array}$ & NA & NA \\
\hline 5473 Santa Monica, Blyd Los Angeles, California, 90029 & NA & NA & 2500 & $\begin{array}{l}3984 \\
15000\end{array}$ & 1925 & $\begin{array}{l}\text { res } \\
\text { Yes }\end{array}$ & NA & NA \\
\hline 6290 W Sunset Blvd Los Angeles, California, 90028 & 4 Commercial Condo \& 10,0 & (15A & 28771 & ${ }_{94009}^{1500}$ & 1961 & $\begin{array}{l}\text { YYes } \\
\text { Yes }\end{array}$ & NA $-67718-\mathrm{CN}$ & NA \\
\hline $\begin{array}{l}1645 \text { Vine St Los Angeles, California, } 90028 \\
1028\end{array}$ & ${ }_{1}^{4 c o m m e}$ & NA & 28500 & $\begin{array}{l}94009 \\
19505\end{array}$ & 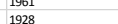 & $\begin{array}{l}\text { YYes } \\
\text { Yes }\end{array}$ & $\begin{array}{ll}11-6 / 72218 \mathrm{CN} \\
\mathrm{V} \pi-6217\end{array}$ & ${ }_{10}^{N A}$ \\
\hline 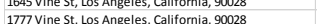 & 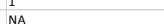 & NA & 22520 & $\begin{array}{l}19505 \\
39248\end{array}$ & ${ }^{1928}$ & $\begin{array}{l}\text { YYes } \\
\text { Yes }\end{array}$ & $\mathrm{NA}-62217$ & ${ }_{10}^{10}$ \\
\hline $201 \mathrm{~N}$ Westmoreland Ave, Los Angeles, California, 9000 & O.NA & NA & 7120 & 28693 & 1935 & No & 7A-2005-3118-7AD & NA \\
\hline 1545 Wilcox Ave, Los Angeles, California 90028 & RECENT ACTIVITY & REA & 6864 & $886902 \& 4.3400$ & $1930 \& 1932$ & Yes & 2A-2005-3118-2AD & NA \\
\hline $\begin{array}{l}5355 \text { Cartwright Ave, Los Angeles, California, } 91601 \\
535 \text {. }\end{array}$ & & 132 & 6761 & $\begin{array}{l}8000284,340.0 \\
80574\end{array}$ & 1958 \& 1932 & $\begin{array}{l}\text { Yes } \\
\text { no }\end{array}$ & $\begin{array}{l}\text { NA } \\
\text { ZA-2003-1666-ZV-ZAA }\end{array}$ & NA \\
\hline $\begin{array}{l}53557 \text { Lankershim Blve, Los Los Angeles, Callolifornia, } 91601 \\
5601\end{array}$ & NA & NA & & & & & & \\
\hline 1839 Blake Ave, Los Angeles, California, 90039 & none & 29 & 34650 & 16314 & 1946 & no & ZA-2003-9199-ZAD & no \\
\hline 1849 Blake Ave, Los Angeles, California, 90039 & none & 29 & 345035 & 10314 & 1956 & no & 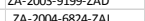 & no \\
\hline 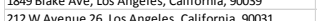 & NA & NA & $\begin{array}{l}34075 \\
5975\end{array}$ & ${ }_{68213}^{21261}$ & 1956 & no & ZA-2004-6824-2AI & no \\
\hline $\begin{array}{l}\text { 212W Avenue 24, Los Angeles, } \\
\text { 2450 Daly St, Los Angeles, California, } 90031\end{array}$ & $\begin{array}{l}\text { REENA ACIVIY } \\
\text { RECENT ACTIVITY }\end{array}$ & $\begin{array}{l}\text { RECENACIVIY } \\
\text { RECENTACTIVITY }\end{array}$ & 6143 & $\begin{array}{l}6813 \\
18544\end{array}$ & 1935 & $\begin{array}{l}\text { res } \\
\text { yes }\end{array}$ & ZA-2004-7710-ZAI & NA \\
\hline $\begin{array}{l}\text { 2450Dalyst, Los Angeles, Calltornia, } \\
2701 \text { N Broadway, Los Angeles, California, } 90031\end{array}$ & $\begin{array}{l}\text { RECENA ACIVIY } \\
\text { RECENT ACTIVITY }\end{array}$ & $\begin{array}{l}\text { RECENACIVIY } \\
\text { RECENT ACTIVITY }\end{array}$ & 67706 & $\begin{array}{l}185244 \\
18210\end{array}$ & ${ }_{1911}^{1935}$ & $\begin{array}{l}\text { yes } \\
\text { yes }\end{array}$ & $\begin{array}{l}\text { ZA-2004-7/7010-ZAI } \\
\text { ZA-2004-682-ZAI }\end{array}$ & NA \\
\hline 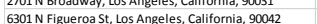 & $\begin{array}{l}\text { ReClet } \\
\text { none }\end{array}$ & REC & 6975 & 182100 & 1926 & $\begin{array}{l}\text { yes } \\
\text { no }\end{array}$ & 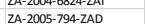 & 253 \\
\hline 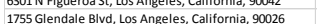 & $\begin{array}{l}\text { none } \\
\text { None }\end{array}$ & 28 & 8330 & 5 different buildings & $\begin{array}{l}196 \\
1946 / 1946 / 1955\end{array}$ & $\begin{array}{l}\text { no } \\
\text { no }\end{array}$ & $\begin{array}{l}\text { ZAA-2005-T994-ACU } \\
\text { VTT-64847-CC }\end{array}$ & $\begin{array}{l}253 \\
253\end{array}$ \\
\hline 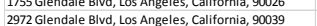 & NA & NA 28 & 2557 & 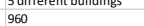 & 1948 & $\begin{array}{l}\text { no } \\
\text { no }\end{array}$ & ZA-2004-6824-ZAI & $\mathrm{NA}$ \\
\hline $\begin{array}{l}2972 \text { G Gendale Bivd, Los Angeles, Californial, } 900 \\
2327 \text { W 54th St, Los Angeles, California, } 90043\end{array}$ & NA & NA & 3578 & 63904 & ${ }_{1922}^{1948}$ & $\begin{array}{l}\text { no } \\
\text { No }\end{array}$ & $\begin{array}{l}\text { ZAA } 2004-6824-\angle- \\
\text { NA }\end{array}$ & NA \\
\hline 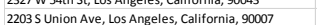 & NA & NA & 2800 & 27390 & ${ }_{1970}^{1922}$ & No & NA & $\begin{array}{l}\text { NA } \\
\text { Non Contributor to Historic District (6Z) }\end{array}$ \\
\hline $\begin{array}{l}12035 \text { Union Ave, Los Angeles, Caltorna, } 9000 \\
1324 \text { Abot Kinney Blvd Los Angeles, California, } 90291\end{array}$ & NA & NA & 2869 & & & No & & \\
\hline 815 Hampton Dr. Los Angeles, California, 90291 & NA & NA & 10306 & & 2008 & NA & PERMIT NUMBER & NA \\
\hline 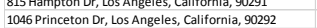 & None & 60 & 46320 & 1892 & 2007 (Not accurate) & None & $\pi-60907-\mathrm{M} 1$ & NA \\
\hline 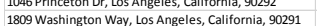 & NA & NA & & & & & & \\
\hline $\begin{array}{l}11500 \text { Tennessee Ave, Los Angeles, California, } 90064 \\
1906\end{array}$ & NA & 210 & & 1745 & 2009 & & 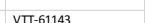 & NA \\
\hline 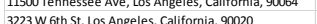 & none & 69 & 59710 & $\mathrm{NA}$ & NA (looks new) & & VIT-65143 & NA \\
\hline 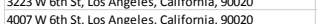 & $\begin{array}{l}\text { none } \\
\text { none }\end{array}$ & NA & 3086 & 5610 & NA (1024 & yes & $\begin{array}{l}\text { VIT-65546-CC } \\
\text { PERMITNUMBER }\end{array}$ & NA \\
\hline 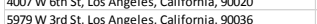 & & 25 & 6530 & 12817 & ${ }_{1924}^{1924}$ & $\begin{array}{l}\text { yes } \\
\text { No }\end{array}$ & $\begin{array}{l}\text { PARMIIN NUMBER } \\
\text { ZA-2004-949-ZAD }\end{array}$ & NA \\
\hline 3800 Wilshire Blvd, Los Angeles, California, 90010 & 27500 sg ft. & 564 & 20134 & 64059 & $\begin{array}{l}1959 \\
1962\end{array}$ & Yes & $\begin{array}{l}2 A-20004-949-\angle A \\
V \pi T-62784-C C\end{array}$ & $\begin{array}{l}\text { HAA } \\
\text { HPOZ }\end{array}$ \\
\hline
\end{tabular}

